\title{
Fractional Crystallization Flowsheet Tests with Actual Tank Waste.
}

\author{
D. I. Herting \\ CH2M HILL Hanford Group, Inc. \\ Richland, WA 99352 \\ U.S. Department of Energy Contract DE-AC27-99RL14047
}

$\begin{array}{ll}\text { EDT/ECN: DRF } & \text { UC: } \\ \text { Cost Center: } 7 S 110 & \text { Charge Code: } \\ \text { B\&R Code: } & \text { Total Pages: } 58\end{array}$

Key Words: fractional, crystallization, process, flowsheet, tank, waste, saltcake, s-farm, SX-farm, feed, Cesium-137, sulfate, sodium, mass balance, separations, decontamination factor, pretreatment

Abstract: Laboratory-scale flowsheet tests of the fractional crystallization process were conducted with actual tank waste samples in a hot cell at the 222-s Laboratory. The process is designed to separate medium-curie liquid waste into a low-curle stream for feeding to supplemental treatment and a high-curie stream for double-shell tank storage. Separations criteria (for Cs-137 sulfate, and sodium) were exceeded in all three of the flowsheet tests that were performed.

TRADEMARK OISCLAIMER. Reference herein to any specific commercial product, process, or service by trade name, trademark, manufacturer, or olherwise, does not necesserily conslitule or imply its endorsement, recommendation, or favoring by the United States Government or any agency thereof or its contractors or subcontractors.

Priated In the United States of America. To obtain coples of this document, contact: Document Control Services, P.O. Box 950, Malislop H6-08, Richland WA 99352, Phone (509) 372-2420; Fax (509) 376-4989.

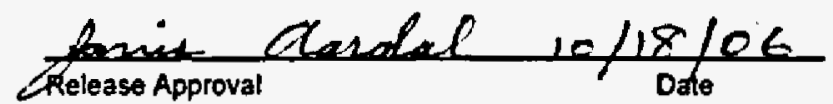

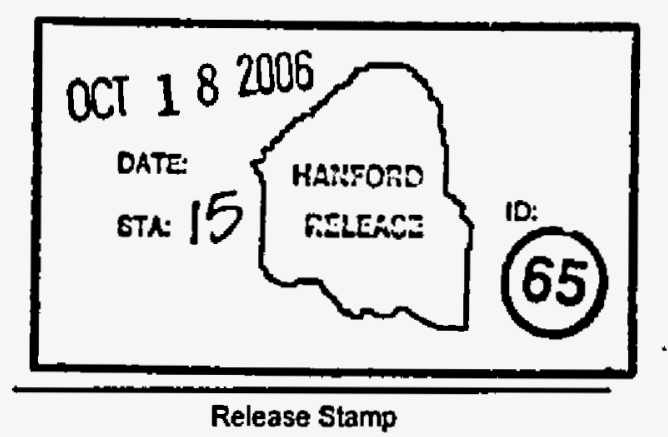




\section{FRACTIONAL CRYSTALLIZATION FLOWSHEET TESTS WITH ACTUAL TANK WASTE}

\section{L. Herting}

CH2M HILL Hanford Group, Inc.

Date Published

October 2006

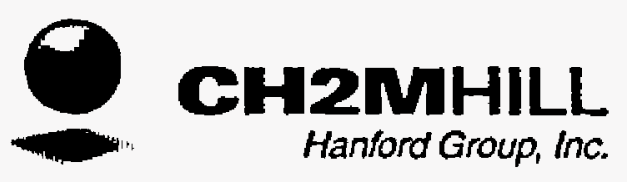

Prepared for the U.S. Department of Energy Office of River Protection

Contract No. DE-AC27-99RL14047

. 


\section{TABLE OF CONTENTS}

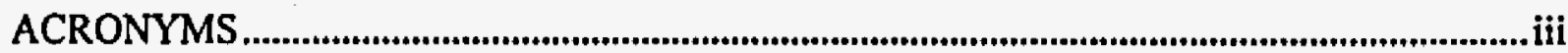

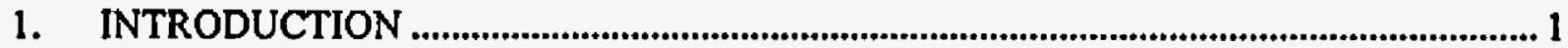

1.1 TEST SUMMARY AND RESULTS ...................................................................... 1

1.2 PRIOR TESTS WITH ACTUAL TANK WASTE ...................................................... 2

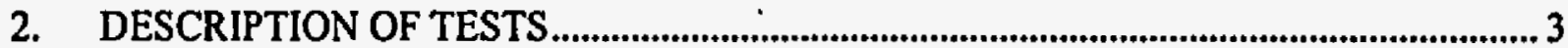

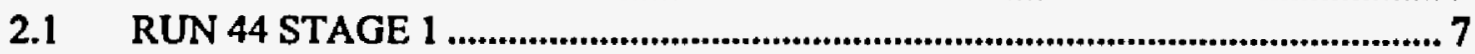

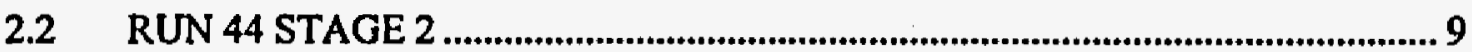

2.3 RUN 46 STAGE 1 ..................................................................................... 12

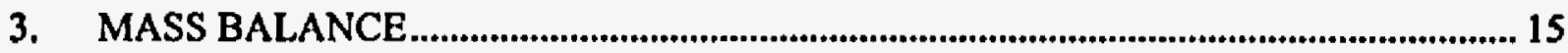

4. CHEMICAL AND RADIONUCLIDE ANALYSES ......................................................... 19

4.1 COMPOSITION OF PROCESS STREAMS …..................................................19

4.2 PHASES PRESENT IN WASHED SOLIDS .....................................................20

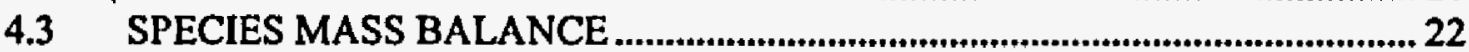

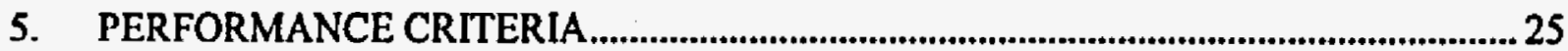

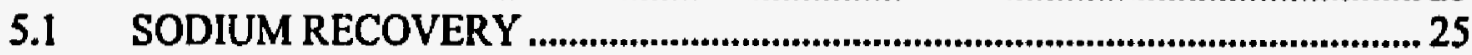

5.2 CESIUM DECONTAMINATION ................................................................... 25

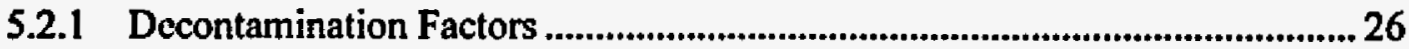

5.2.2 Variations in Decontamination Factor ..............................................................2 27

5.3 SULFATE:SODIUM MOLE RATIO.................................................................... 29

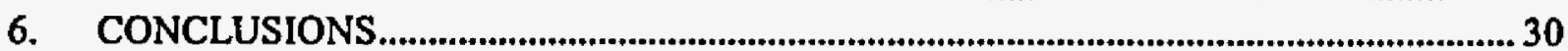

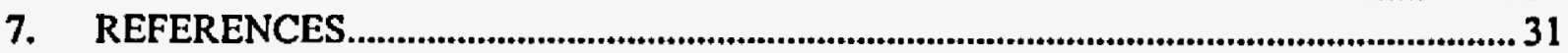

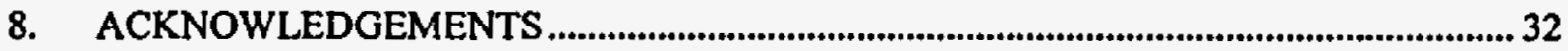

APPENDIX: ANALYTICAL SAMPLE RESULTS AND DILUTION FACTORS...................A-i

\section{LIST OF FIGURES}

Figure 2-1. SST Early Design Flowshect. ............................................................................................ 4

Figure 2-2. SST Late Design Flowshect .................................................................................... 5

Figure 2-3. Redesigned Apparatus Staged for Hot Cell Installation. ..............................................6 6

Figure 2-4. Temperature and Pressure Profiles for Run 44 Stage 1 .................................................... 7

Figure 2-5. Evaporation Profile for Run 44 Stage 1 ....................................................................... 8

Figure 2-6. PLM Images of Washed Crystals from Run 44 Stage 1............................................... 8

Figure 2-7. SEM Image and EDS Spectrum of $\mathrm{Na}_{3} \mathrm{FSO}_{4}$ Phase from Run 44 Stage 1................ 9

Figure 2-8. SEM Image and EDS Spectrum of Sodium Sulfate Phase from Run 44 Stage 1....... 9

Figure 2-9. Temperature and Pressure Profiles for Run 44 Stage 2 ............................................. 10

Figure 2-10. Evaporation Profile for Run 44 Stage 2 ....................................................................... 11

Figure 2-11. PLM Images of Washed Crystals from Run 44 Stage 2 .......................................... 11

Figure 2-12. SEM Image and EDS Spectrum of $\mathrm{Na}_{7} \mathrm{~F}\left(\mathrm{PO}_{4}\right)_{2} \cdot 19 \mathrm{H}_{2} \mathrm{O}$ from Run 44 Stage 2. ...... 12

Figure 2-13. Temperature and Pressure Profiles for Run 46 ............................................................ 13

Figure 2-14. Evaporation Profile for Run 46 ..................................................................................... 13

Figure 2-15. PLM Images of Washed Crystals from Run 46 ........................................................ 14

Figure 2-16. SEM Image and EDS Spectrum of $\mathrm{Na} 7 \mathrm{~F}\left(\mathrm{PO}_{4}\right)_{2} \cdot 19 \mathrm{H}_{2} \mathrm{O}$ from Run $46 \mathrm{Stage} 1$....... 14

Figure 3-1. Mass Balance for SST Early Run 44 Stage 1 ............................................................... 16 


\section{RPP-RPT-31352, Rev. 0}

Figure 3-2. Mass Balance for SST Early Run 44 Stage 2............................................................... 17

Figure 3-3. Mass Balance for SST Late Run 46 Stage 1 .................................................................. 18

\section{LIST OF TABLES}

Table 1-1. All Test Results Exced Performance Criteria ...................................................................... 2

Table 2-1. Composition of SST Early and SST Late Feed Solutions.............................................. 3

Table 3-1. Mass Balance Closure; Stream Weights in Grams...................................................... 15

Table 4-1. Dilution-Corrected Analytical Results for Run 44 Stage 1 ........................................ 19

Table 4-2. Dilution-Corrected Analytical Results for Run 44 Stage 2 ............................................ 21

Table 4-3. Dilution-Corrected Analytical Results for Run 46 Stage 1.........................................22

Table 4-4. Composition of Wash Liquids......................................................................................... 22

Table 4-5. Species Mass Balance, Run 44 Stage 1 ......................................................................... 23

Table 4-6. Species Mass Balance, Run 44 Stage 2 ............................................................................ 23

Table 4-7. Species Mass Balance, Run 46 Stage 1 ............................................................................ 24

Table 5-1. Decontamination Factors.......................................................................................... 27 
RPP-RPT-31352, Rev. 0

\section{ACRONYMS}

$\begin{array}{ll}\text { C/F } & \text { condensate-to-feed } \\ \text { DF } & \text { decontamination factor } \\ \text { EDS } & \text { energy dispersive spectrometer } \\ \text { Georgia Tech } & \text { Georgia Institute of Technology } \\ \text { ISL } & \text { interstitial liquid } \\ \text { PLM } & \text { polarized light microscopy } \\ \text { S-112 } & \text { tank 241-S-112 } \\ \text { SEM } & \text { scanning electron microscope } \\ \text { TIC } & \text { total inorganic carbon } \\ \text { TOC } & \text { total organic carbon } \\ \text { XRD } & \text { X-ray diffraction }\end{array}$




\section{INTRODUCTION}

Laboratory-scale flowsheet tests of the fractional crystallization process were conducted with actual tank waste samples in a hot cell at the 222-S Laboratory. The fecd solutions were composite samples of dissolved saltcake from several S-farm and SX-farm tanks. Preparation and analysis of the feed samples have been described elsewhere (external letter CH2M-0600248, "Preparation of Composite Tank Waste Samples for EM-21 Project"). Two composite samples were prepared: "SST Early," representing the typical composition of dissolved saltcake early in the retrieval process, and "SST Late," representing the typical composition during the later stages of retrieval. Sec Table 2-1 for a summary of the compositions of both feed solutions.

Prior reports on fractional crystallization (RPP-RPT-26474, Fractional Crystallization of Waste from Tank 241-S-112, and RPP-RPT-27239, Hanford Mcdium/Low Curic Waste Pretreatment Project - Phase I Laboratory Report) include adequate descriptions of the historical background, theory, and application of the fractional crystallization process, details of which will not be repeated here. In very brief terms, the liquid waste formed during retrieval of saltcake waste from single-shell tanks represents the feed for the fractional crystallization process. Within the fractional crystallization plant, the waste is evaporated to form sodium salt crystals. The bulk of the radionuclides-especially ${ }^{137} \mathrm{Cs}$, ${ }^{99} \mathrm{Tc}$, and ${ }^{129} \mathrm{I}$-remain in the liquid phase. The slurry is filtered or centrifuged and the solids are washed to remove interstitial liquid (ISL). The highactivity filtrate or centrate is routed to a double-shell tank for storage and the spent wash solution is recycled to the evaporator. The washed solids are dissolved to create feed for a supplemental treatment facility (e.g., bulk vitrification).

\subsection{TEST SUMMARY AND RESULTS}

Three hot cell flowshcet tests were performed. Using the numbering scheme applied to prior simulated waste flowsheet tests performed at both the Georgia Institute of Technology (Georgia Tech) and at the 222-S Laboratory, the three tests with actual tank waste were designated:

a. Run 44 Stage 1-SST Early composite sample feed.

b. Run 44 Stage 2-SST Early filtrate from Stage 1 used as feed for Stage 2.

c. Run 46 Stage 1-SST Late composite sample feed (no Stage 2 performed).

Analytical samples of process input and output streams allowed for evaluation of the process performance against the criteria established in the Statement of Work, as well as component-bycomponent mass balance across the process. As shown in Table 1-1, all of the criteria for scparations $\left({ }^{137} \mathrm{Cs}\right.$ removal, sulfate removal, and $\mathrm{Na}^{+}$separation) were exceeded in all three tests. Mass balance closure was acceptable for all system components except ${ }^{90} \mathrm{Sr}$. 
Table 1-1. All Test Results Exceed Performance Criteria.

\begin{tabular}{|c|c|c|c|c|}
\hline \multirow[b]{2}{*}{ Measurement } & \multirow[b]{2}{*}{ Criterion } & \multicolumn{2}{|c|}{ Run 44} & \multirow{2}{*}{$\begin{array}{l}\text { Run } 46 \\
\text { Stage } 1 \\
\end{array}$} \\
\hline & & Stage 1 & Stage 2 & \\
\hline $\begin{array}{l}\text { Na diverted to supplemental } \\
\text { treatment }\end{array}$ & $>50 \%$ & \multicolumn{2}{|c|}{$75.2 \%$ (combined) } & $71.5 \%$ \\
\hline${ }^{137} \mathrm{Cs}$ activity in product & $\begin{array}{c}<1.23 \mathrm{E}-3 \mathrm{Ci} / \mathrm{mol} \\
\mathrm{Na}^{+}\end{array}$ & $6.2 \mathrm{E}-5$ & $5.5 \mathrm{E}-5$ & $1.0 \mathrm{E}-4$ \\
\hline $\begin{array}{l}\text { Sulfate:sodium mole ratio in } \\
\text { purge stream }\end{array}$ & $<0.01$ & Not applicable & 0.0047 & 0.00045 \\
\hline
\end{tabular}

\subsection{PRIOR TESTS WITH ACTUAL TANK WASTE}

These were not the first fractional crystallization process tests to be performed with actual tank waste. Prior tests were performed using liquid samples taken directly from tank 241-S-112 (S-112) during retrieval operations. Some discussion of the differences between the two sets of tests is in order.

The two liquid composite samples used for the S-112 tests (Sampling Event 2 and Sampling Event 3) correspond roughly to the SST Early and SST Late composite samples used in the current tests. However, the saltcake in tank S-112 was atypical in the sense that it was more heavily dominated by $\mathrm{NaNO}_{3}$ than the "average" saltcake. Hence, the chemical compositions of . SST Early and SST Late samples tend to be two to four times higher than Sampling Event 2 and 3 samples in all non-nitrate analytes except chromium and sodium. The SST Late composite sample is about 10 times higher in fluoride and oxalate than the corresponding Sampling Event 3 composite sample. As a result of these feed differences, crystalline products from the current SST Early and SST Late flowshect tests contain a much higher proportion of non-nitrate salts than the products of the S-112 tests.

There were many procedural differences between the two sets of tests as well. The current tests were performed on a 10-times-larger scale and under conditions more closely resembling the operating conditions planned for the full-scale plant, such as more moderate evaporation temperatures (40-66 $6^{\circ} \mathrm{C}$ in the current tests vs. $30-80^{\circ} \mathrm{C}$ in the S-112 tests). The current tests used a far more efficient filter cake washing procedure, resulting in much improved solid/liquid separations. 


\section{DESCRIPTION OF TESTS}

The flowsheets for the SST Early (Run 44) and SST Late (Run 46) fractional crystallization process are shown in Figures 2-1 and 2-2. The feed compositions are shown in Table 2-1. The equipment and procedural details were largely as described for the simulated waste tests performed at the Georgia Institute of Technology (Georgia Tech) (RPP-RPT-27239) with some equipment modifications to make the system more "hot cell friendly." Those modifications included the following (see callouts in Figure 2-3):

a. Condenser oriented vertically, instead of horizontally, to reduce the footprint.

b. Feed added by vacuum siphon, instead of pouring, to reduce chance of spillage.

c. Crystallizer drain valves replaced by quarter-turn stopcocks for easier manipulator operation of the valves.

d. Both large and small crystallizers mounted on single frame to allow for minimal configuration changes inside the hot cell.

Table 2-1. Composition of SST Early and SST Late Feed Solutions. (Analyte concentrations in molarity, except as noted.)

\begin{tabular}{|c|c|c|c|}
\hline Analyte & SST Early & SST Late & Early/Late \\
\hline $\mathrm{Wt}_{\mathrm{t}} \% \mathrm{H}_{2} \mathrm{O}$ & 57.8 & 89.4 & - \\
\hline Density, $\mathrm{g} / \mathrm{mL}$. & 1.32 & 1.06 & - \\
\hline $\mathbf{A l}$ & 0.289 & 0.039 & 7.4 \\
\hline $\mathrm{Cr}$ & 0.019 & 0.003 & 6.3 \\
\hline $\mathbf{K}$ & 0.018 & 0.003 & 6.0 \\
\hline $\mathrm{Na}$ & 6.309 & 1.201 & 5.3 \\
\hline$\underline{\mathbf{P}}$ & 0.046 & 0.025 & 1.8 \\
\hline $\mathbf{S}$ & 0.138 & 0.023 & 6.0 \\
\hline $\mathrm{Si}$ & 0.006 & 0.002 & 3.0 \\
\hline $\mathbf{F}$ & 0.010 & 0.052 & 0.2 \\
\hline $\mathrm{Cl}$ & 0.073 & 0.013 & 5.6 \\
\hline $\mathrm{NO}_{2}$ & 0.515 & 0.071 & 7.3 \\
\hline $\mathrm{NO}_{3}$ & 3.276 & 0.530 & 6.2 \\
\hline $\mathrm{PO}_{4}$ & 0.046 & 0.024 & 1.9 \\
\hline $\mathrm{SO}_{4}$ & 0.128 & 0.021 & 6.1 \\
\hline Oxalate & 0.006 & 0.054 & 0.1 \\
\hline $\mathrm{CO}_{3}$ & 0.614 & 0.099 & 6.2 \\
\hline Total organic carbon & 0.083 & 0.110 & 0.8 \\
\hline OII & 0.618 & 0.100 & 6.2 \\
\hline${ }^{137} \mathrm{Cs}, \mu \mathrm{Ci} / \mathrm{mL}$ & 59.9 & 9.40 & 6.4 \\
\hline${ }^{90} \mathrm{Sr}, \mu \mathrm{Ci} / \mathrm{mL}$ & 0.060 & 0.008 & 7.5 \\
\hline${ }^{129} \mathrm{I}, \mu \mathrm{Ci} / \mathrm{mL}$ & 5.5E-5 & $6.9 \mathrm{E}-6$ & 6.1 \\
\hline${ }^{99} \mathrm{Tc}, \mu \mathrm{g} / \mathrm{mL}$ & 3.68 & 0.601 & 8.0 \\
\hline Mass balance & 92.7 & 97.4 & - \\
\hline Charge balance $(t /-)$ & 0.98 & 0.97 & - \\
\hline
\end{tabular}


RPP-RPT-31352, Rev. 0

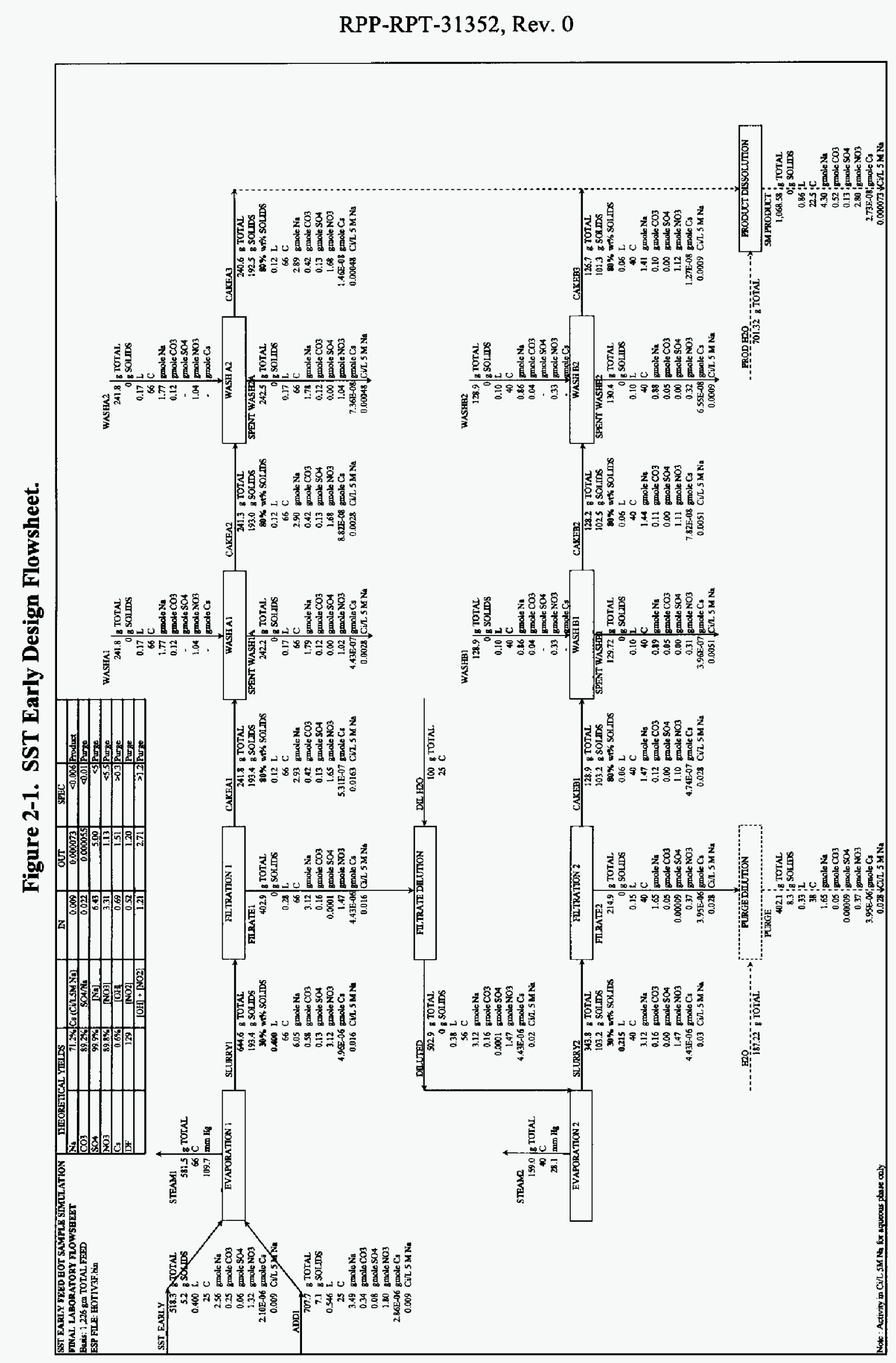




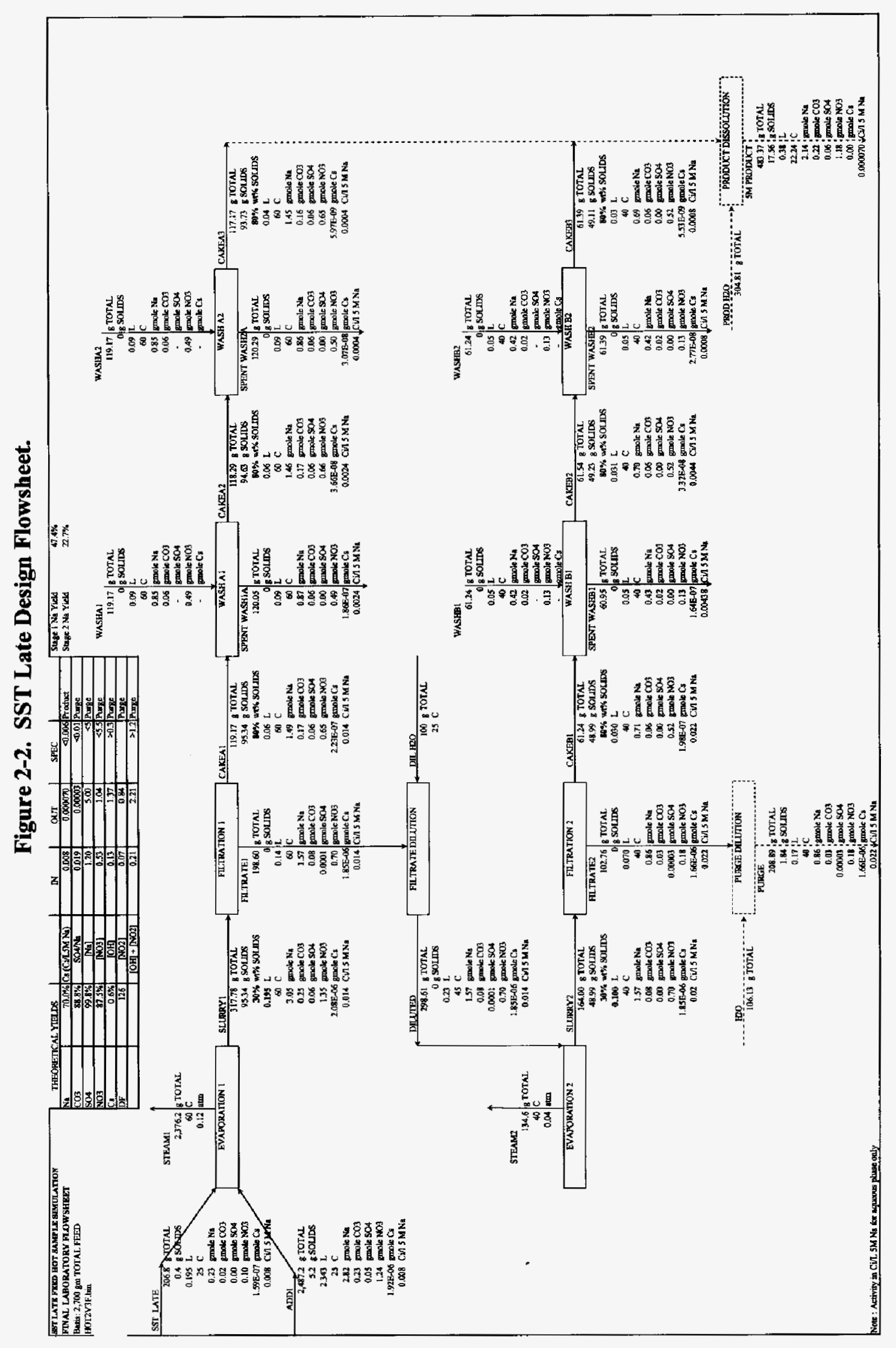


Figure 2-3. Redesigned Apparatus Staged for Hot Cell Installation.

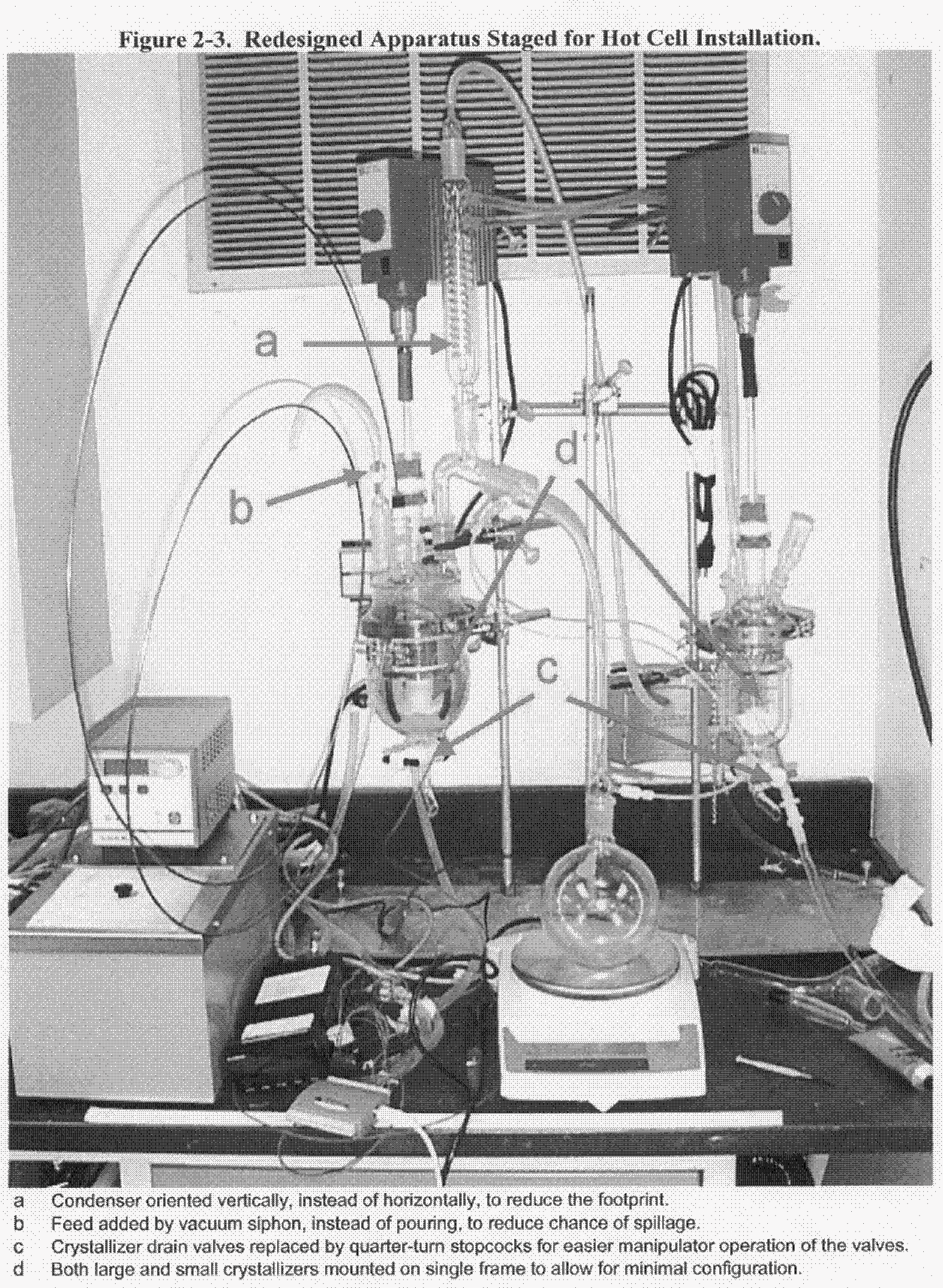

a Condenser oriented vertically, instead of horizontally to reduce the footprint.

b Feed added by vacuum siphon, instead of pouring, to reduce chance of spllage:

o. Crystallizer drain valves replaced by quarter-turn stopcocks for easler manipulator operation of the valves.

d Both large and small cystallizers mounted on single frame to allow for minimal conffguration. 


\subsection{RUN 44 STAGE 1}

Run 44 began with a charge of $400 \mathrm{~mL}$ of SST Early feed solution to the crystallizer. Pressure was adjusted to maintain constant boiling at $66^{\circ} \mathrm{C}$. Fresh feed was added periodically by vacuum siphon to maintain a constant volume in the crystallizer.

Temperature and pressure profiles for Stage 1 are presented in Figure 2-4. Throughout the run the temperature was controlled to within $\pm 1{ }^{\circ} \mathrm{C}$ of the target value of $66^{\circ} \mathrm{C}$. The cvaporation profile is shown in Figure $2-5$. The evaporation time was $25.5 \mathrm{~h}$, and the average evaporation rate was about $24 \mathrm{~g}$ water/h. All physical aspects of the evaporation were qualitatively the same as the previous tests with simulated waste samples - the gradual onset of nucleation at approximately $230250 \mathrm{~g}$ of condensate collected, the amount of foaming of the slurry (which was manageable), and the thickness of the slurry at the evaporation endpoint.

The endpoint of each run was determined by monitoring the condensate-to-feed (C/F) ratio. The target C/F ratio for Run 44 Stage 1 was 0.474 ; the actual ratio achieved was 0.469 , based on the measured mass of $620.17 \mathrm{~g}$ condensate and $1321.84 \mathrm{~g}$ feed. (The target CF ratio is difficult to "hit right on" because of minor changes in condensate weight that occur after the evaporation is terminated.)

Figure 2-4. Temperature and Pressure Profiles for Run 44 Stage 1.

(Dotted line represents the target operating temperature of $66^{\circ} \mathrm{C}$ )

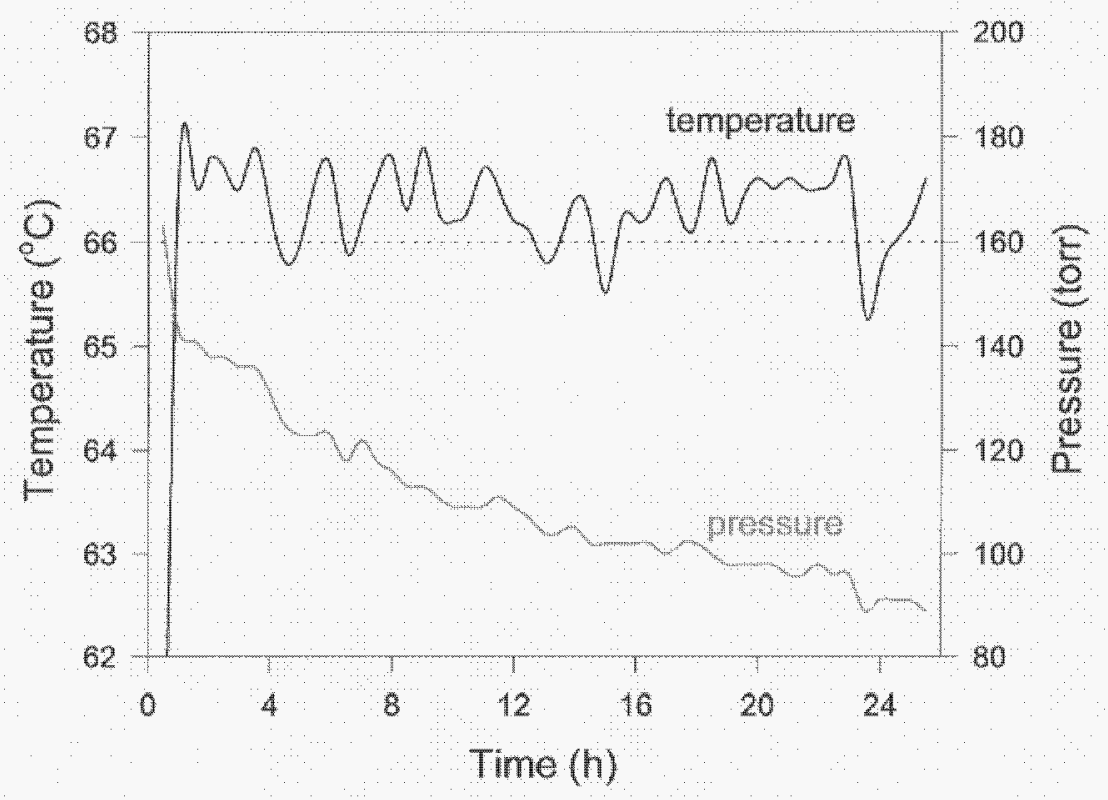


Figure 2-5. Evaporation Profile for Run 44 Stage 1.

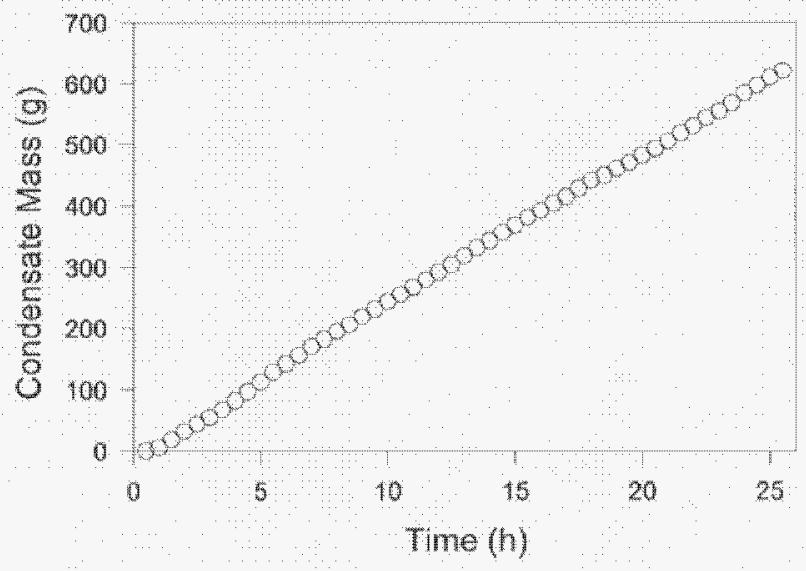

The slurry was drained from the crystallizer only after considerable effort was applied to dislodge the plug that had formed in the drain line. The slurry was filtered using a temperaturecontrolled vacuum filter apparatus. The filtrate was diluted with water to prevent precipitation. After sampling, the remaining diluted filtrate became the feed for Stage 2. The filtered solids were sampled for analysis and then washed five times with a caustic (NaOH-containing) solution saturated in $\mathrm{NaNO}_{3}, \mathrm{Na}_{2} \mathrm{CO}_{3}$, and $\mathrm{NaF}$. The washed crystals and the spent wash liquid were also sampled for analysis.

The crystallizer was filled with fresh water to dissolve the "accumulation" the solid material that remains in the crystallizer after draining the slurry. The resulting liquid was collected and sampled for analysis for mass balance elosure purposes.

Figure 2-6 displays the polarized light microscopy (PLM) images of the washed crystals, with the left photo emphasizing $\mathrm{NaNO}_{3}$ crystals and the right photo emphasizing $\mathrm{Na}_{2} \mathrm{CO}_{3} \cdot \mathrm{H}_{2} \mathrm{O}$ crystals, both of which were present in abundance in the washed and unwashed samples. Both samples also contained quite a bit of relatively small crystalline material too small to identify by PLM.

Figure 2-6. PLM Images of Washed Crystals from Run 44 Stage 1.

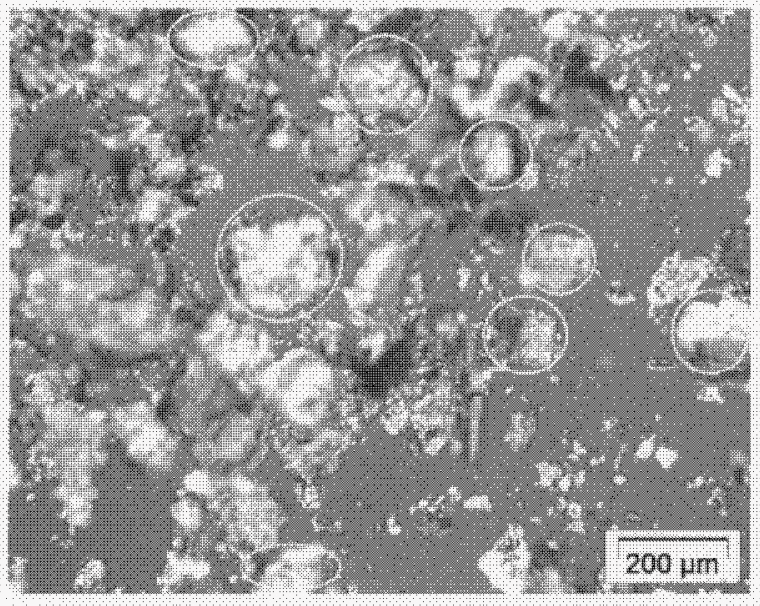

Emphasis on $\mathrm{NaNO}_{3}$ (examples circled).

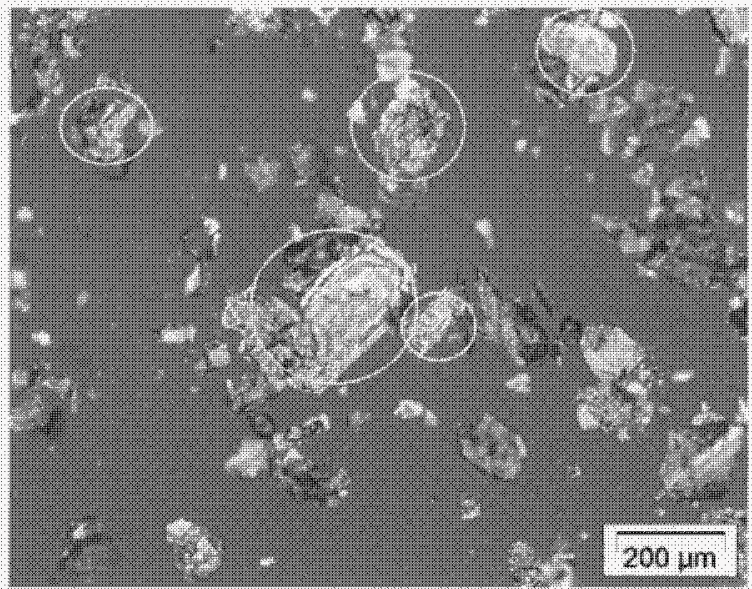

Limphasis on $\mathrm{Na}_{2} \mathrm{CO}_{3} \cdot \mathrm{H}_{2} \mathrm{O}$ (examples circled). 
X-ray diffraction (XRD) analysis was also performed on the washed crystals. The XRD spectrum revealed a composition consisting primarily of $\mathrm{NaNO}_{3}$ with significant amounts of $\mathrm{Na}_{2} \mathrm{CO}_{3} \cdot \mathrm{H}_{2} \mathrm{O}$.

The sample was also examined on a scanning electron microscope (SEM) equipped with an energy dispersive spectrometer (EDS) for chemical analysis. The SEM analysis was consistent with PLM and XRD in finding $\mathrm{NaNO}_{3}$ and $\mathrm{Na}_{2} \mathrm{CO}_{3} \cdot \mathrm{H}_{2} \mathrm{O}$ were the dominant particle types. In addition, the fine particulate could be characterized on the SEM. These fines, which coated the coarser particulate, consisted of fragments or smaller crystals of the two phases already identified, as well as several others phases. The additional minor phases include minor amounts of $\mathrm{Na}_{2} \mathrm{C}_{2} \mathrm{O}_{4}$ and one or more sodium sulfate phases. Figure $2-7$ shows the secondary electron image and EDS spectrum of particulate that is consistent with $\mathrm{Na}_{3} \mathrm{FSO}_{4}$, while Figure 2-8 is an: example of a sodium sulfate phase [possibly $\left.\mathrm{Na}_{6} \mathrm{CO}_{3}\left(\mathrm{SO}_{4}\right)_{2}\right]$ that does not contain the fluoride.

Figure 2-7. SEM Image and EDS Spectrum of NaysSO 4 Phase from Run 44 Stage 1.
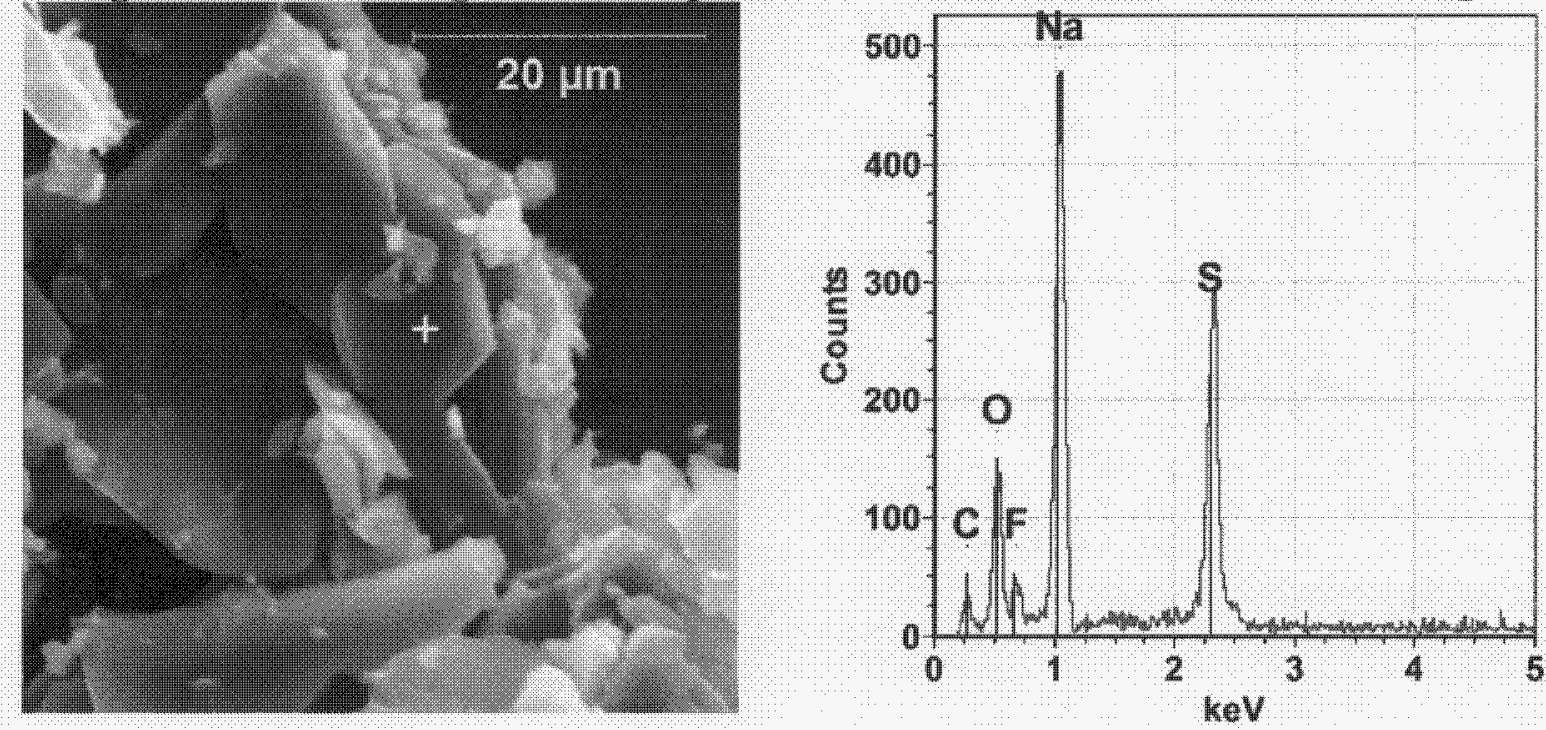

Figure 2-8. SEM Image and EDS Spectrum of Sodiun Sulfate Phase from Run 44 Stage 1.
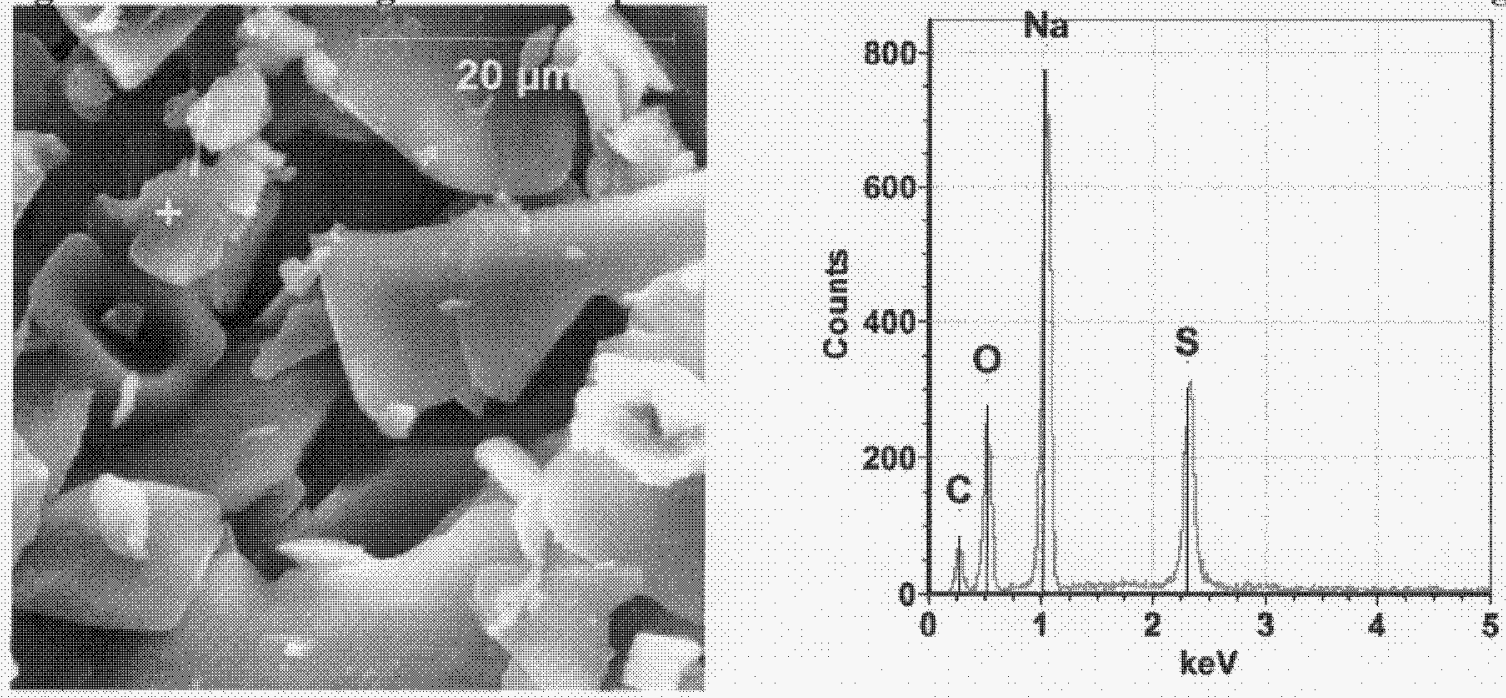


\section{RPP-RPT-31352, Rev. 0}

\subsection{RUN 44 STAGE 2}

The diluted filtrate from Stage 1, minus a small aliquot for chemical and radionuclide analysis, became the feed for Stage 2 . The small crystallizer was used, and the volume was held constant at $200 \mathrm{~mL}$.

The target CF ratio was different from that shown in the flowsheet (Figure 2-1) because the actual weights of Stage 1 filtrate and dilution water differed from the llowsheet values. The formula used to calculate the target C/F ratio for Stage 2 is the following:

$$
C / F=[E 2 d-(E 2 d)(F / \mathrm{W} / \mathrm{d})(344 / 403)] / \mathrm{E} 2 \mathrm{~d}
$$

where E2d is the measured weight of dilute Stage 2 feed, F1u is the measured weight of undiluted Stage 1 filtrate, Fld is the measured weight of diluted Stage 1 filtrate, 344 is the tlowsheet value for the weight of Stage 2 slurry, and 403 is the flowsheet value for the weight of Stage 2 undiluted feed. For Run 44, the calculated target C/F ratio for Stage 2 was 0.459 . The actual C/F ratio, based on the measured mass of $227.51 \mathrm{~g}$ condensate and $490,84 \mathrm{~g}$ feed, was 0.464 .

Temperature and pressure profiles for the evaporation are presented in Figure 2-9. Throughout the run the temperature was controlled to within $\pm 2^{\circ} \mathrm{C}$ of the target value of $40^{\circ} \mathrm{C}$ except for a slight excursion near the end of the evaporation. (At pressures below 20 torr, very small adjustments to the pressure regulating valve cause relatively large changes in the system boiling temperature.)

Figure 2-9. Temperature and Pressure Profiles for Run 44 Stage 2. (Dotted line represents the target operating temperature of $40^{\circ} \mathrm{C}$ )

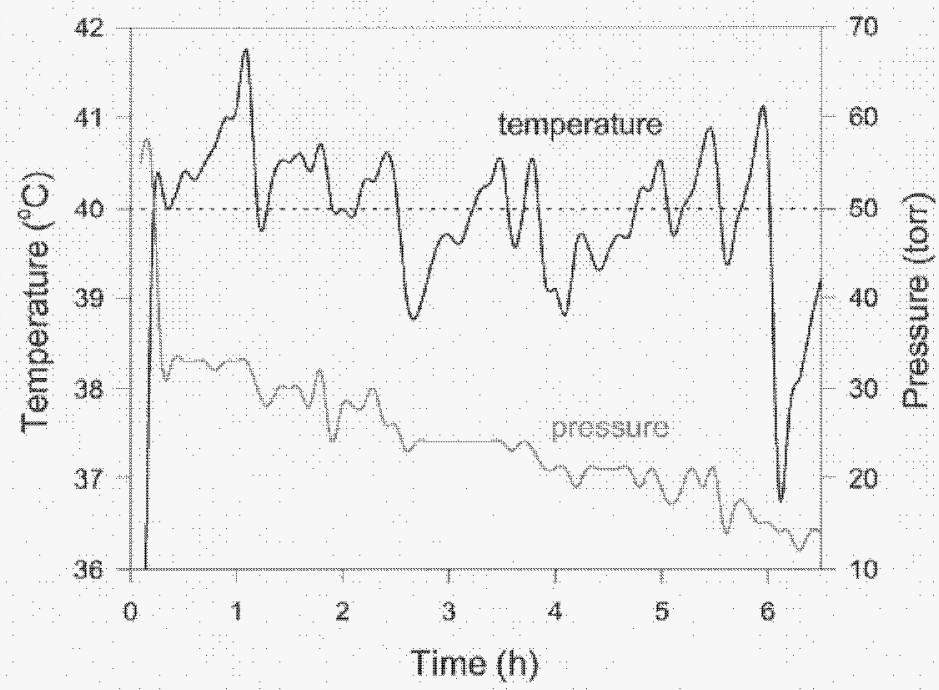

The evaporation profile for Stage 2 is shown in Figure 2-10. The evaporation time was $6.6 \mathrm{~h}$, and the average evaporation rate was about $34.5 \mathrm{~g}$ water/h. All physical aspects of the evaporation were qualitatively the same as the previous tests with simulated waste samples - the gradual onset of nucleation at approximately $5570 \mathrm{~g}$ of condensate collected, the amount of 
foaming of the slurry (which was manageable), and the thickness of the slurry at the evaporation endpoint.

Figure 2-10. Evaporation Profile for Run 44 Stage 2.

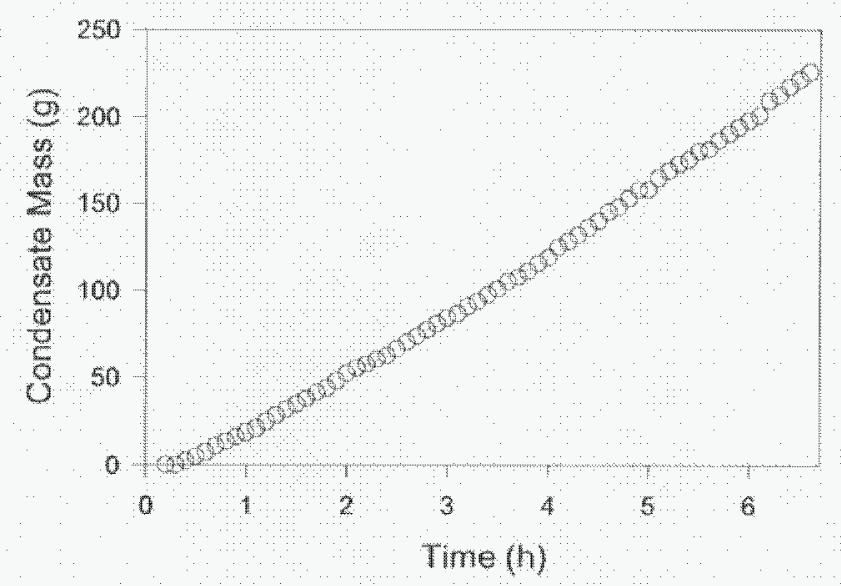

The product slurry, which drained easily when the valve was opened, was filtered and washed in the same fashion as Stage 1. The necumulation was also collected and sampled for analysis as described for Stage 1.

The Stage 2 filtrate represents the "purge" stream - the process stream that will be returned to the double-shell tanks for storage in the actual operating process. The washed crystals from both stages represent the product salt(s) that will be dissolved and routed to the supplemental treatment process (e.g, bulk vitrification) for tinal disposal.

Figure $2-11$ displays the PLM images of samples of the washed solids, with the left photo emphasizing more typical $\mathrm{NaNO}_{3}$ crystals and the right photo emphasizing the tiny particulate, which includes some $\mathrm{NaNO}_{3}$ thombs but is predominately a different, unidentified phase.

Figure 2-11. PLM Images of Washed Crystals from Run 44 Stage 2.

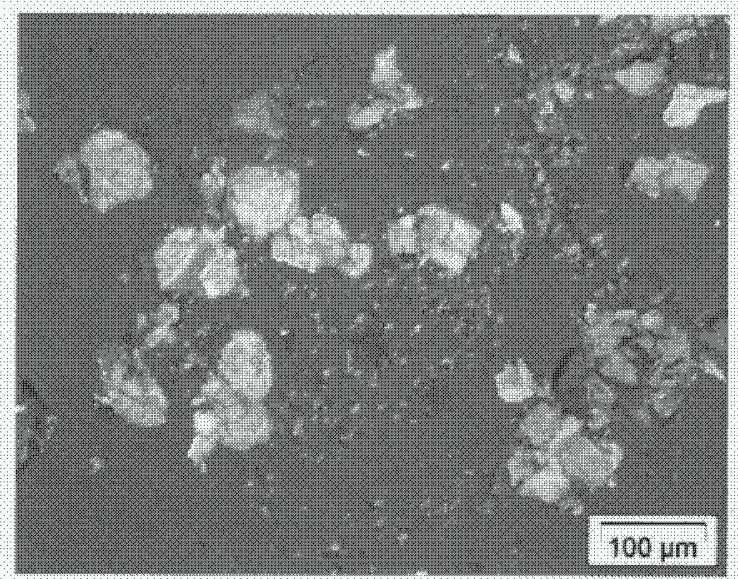

Typical view, dominated by $\mathrm{NaNO}_{3}$.

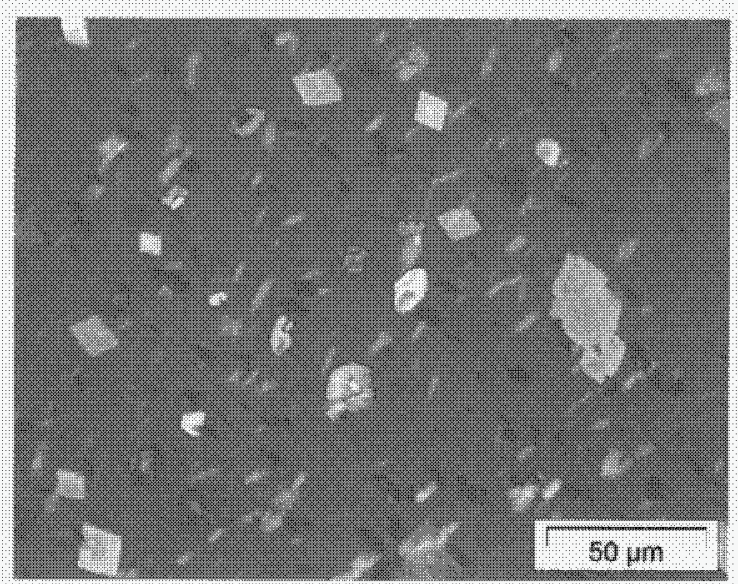

Emphasis on smaller particulate. 
The XRD analysis of this sample was dominated by $\mathrm{NaNO}_{3}$ with lesser amounts of $\mathrm{Na}_{2} \mathrm{CO}_{3} \mathrm{H}_{2} \mathrm{O}$. In addition, minor amounts of $\mathrm{Na}_{2} \mathrm{C}_{2} \mathrm{O}_{4}$ and $\mathrm{Na} \mathrm{F}_{2}\left(\mathrm{PO}_{4}\right)_{2} \cdot 19 \mathrm{H}_{2} \mathrm{O}$ were identified in the XRD spectrum.

The SEM analysis revealed all of the phases observed in the Run 44 Stage 1 sample except for the fluoride-free sulfate phase. The SEM confirmed the presence of $\mathrm{Na}_{7} \mathrm{~F}\left(\mathrm{PO}_{4}\right)_{2} \cdot 19 \mathrm{H}_{2} \mathrm{O}$ in these solids (Figure $2-12$ ).

Figure 2-12. SEM Image and EDS Spectrum of $\mathrm{Na}_{2} \mathrm{~F}\left(\mathrm{PO}_{4}\right)_{2} 19 \mathrm{H}_{2} \mathrm{O}$ from Run 44 Stage 2 .
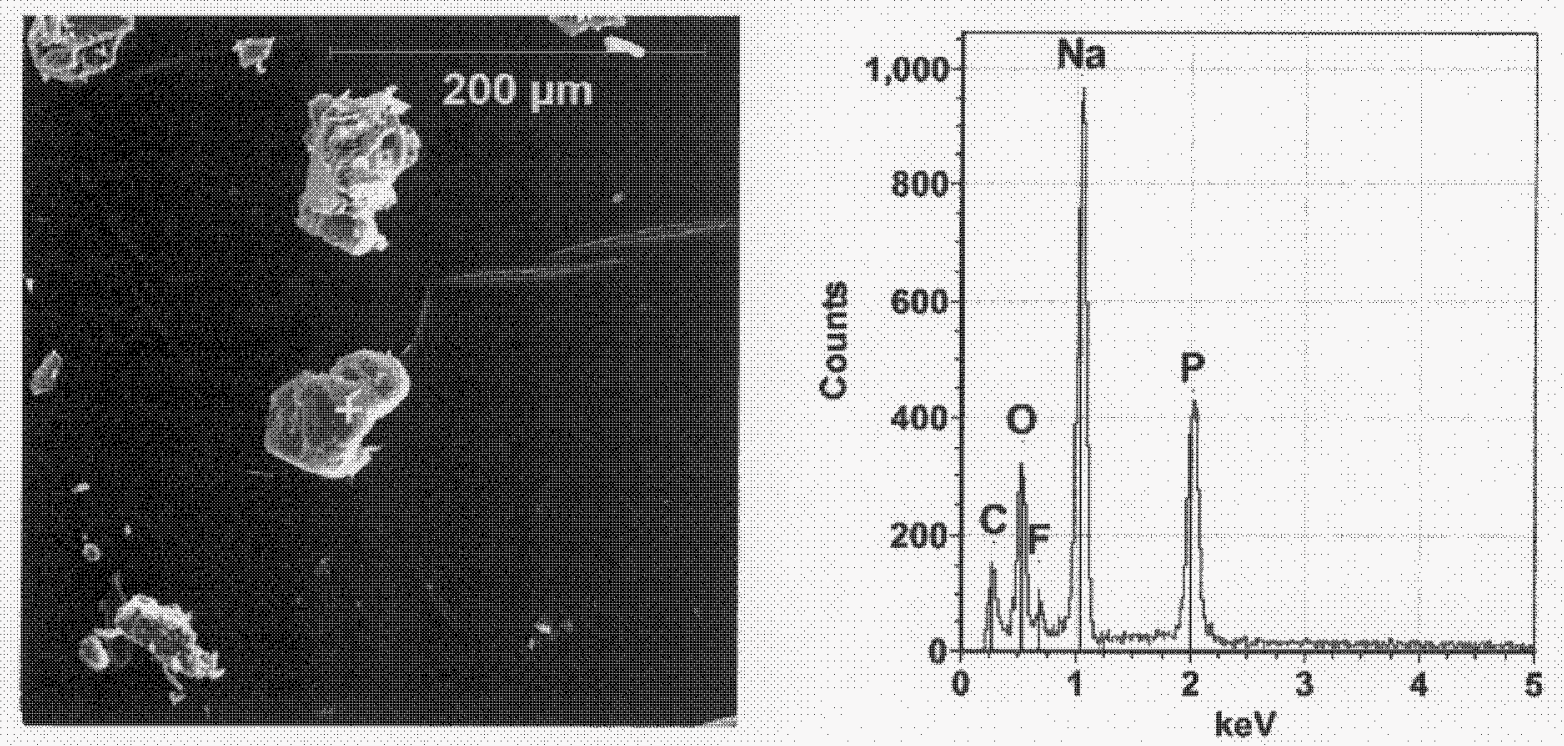

\section{$2.3 \quad$ RUN 46 STAGE I}

Run 46 began with a charge of $200 \mathrm{~mL}$ of SST Late feed solution to the small crystallizer. Pressure was adjusted to maintain boiling at $60^{\circ} \mathrm{C}$. Fresh feed was added periodically by vacuum siphon to maintain a constant volume in the crystallizer.

Temperature and pressure profiles for Run 46 are presented in Figure 2-13. Throughout the run the temperature was controlled to within $\pm 1^{\circ} \mathrm{C}$ of the target value of $60^{\circ} \mathrm{C}$ except for a brief excursion to $58^{\circ} \mathrm{C}$ at about $20 \mathrm{~h}$ into the run. The pressure profile displays the step-wise changes in vacuum level, which correspond to adjustments of the regulating valve.

The evaporation profile for Run 46 is shown in Figure 2-14. The target and actual C/F ratios were 0.882 and 0.878 , respectively, based on the measured mass of $1926.16 \mathrm{~g}$ condensate collected and $2194.55 \mathrm{~g}$ feed. The evaporation time for Run $46 \mathrm{was} 24.5 \mathrm{~h}$, and the average evaporation rate was about $79 \mathrm{~g}$ water/h. Physical aspects of the evaporation were qualitatively the same as the previous tests with simulated waste samples the gradual onset of nucleation at approximately $140-190 \mathrm{~g}$ of condensate collected, and the thickness of the slurry at the evaporation endpoint. Foaming became problematic early in the evaporation but was virtually eliminated by raising the stirring motor specd.

As in Run 44 Stage 1, a plug formed in the drain line. In this case, however, the plug was relatively easy to dislodge, and the slurry drained easily. 
Figure 2-13. Temperature and Pressure Profiles for Run 46. (Dotted line represents the target operating temperature of $60^{\circ} \mathrm{C}$.)

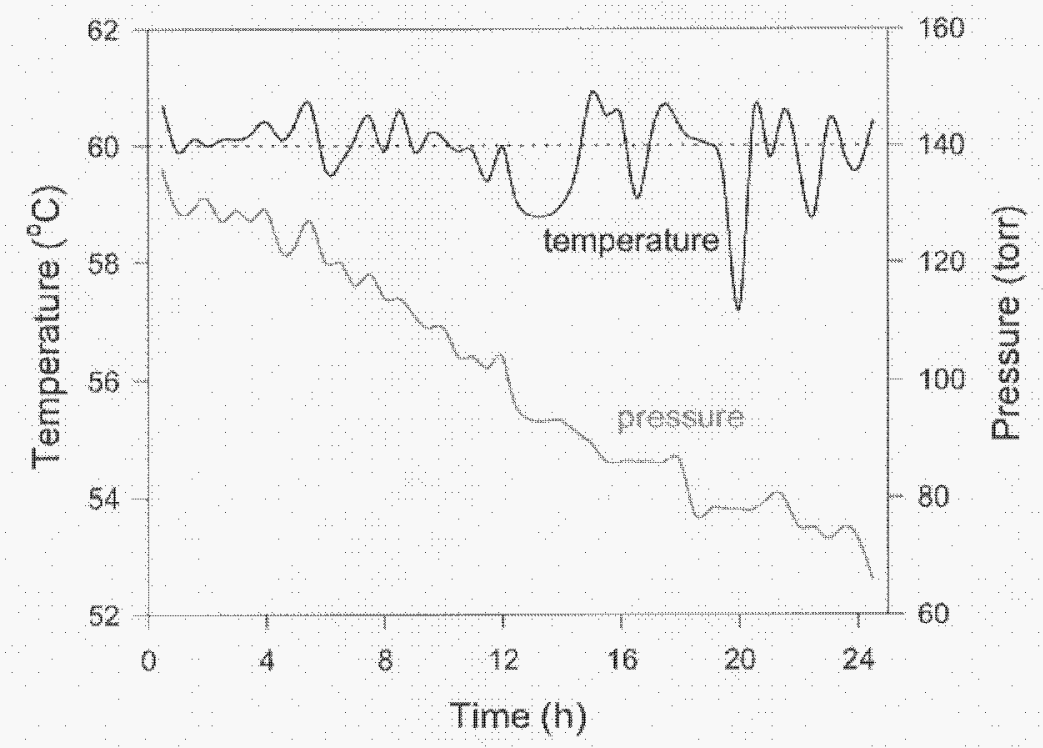

Tigure 2-14. Evaporation Profile for Run 46.

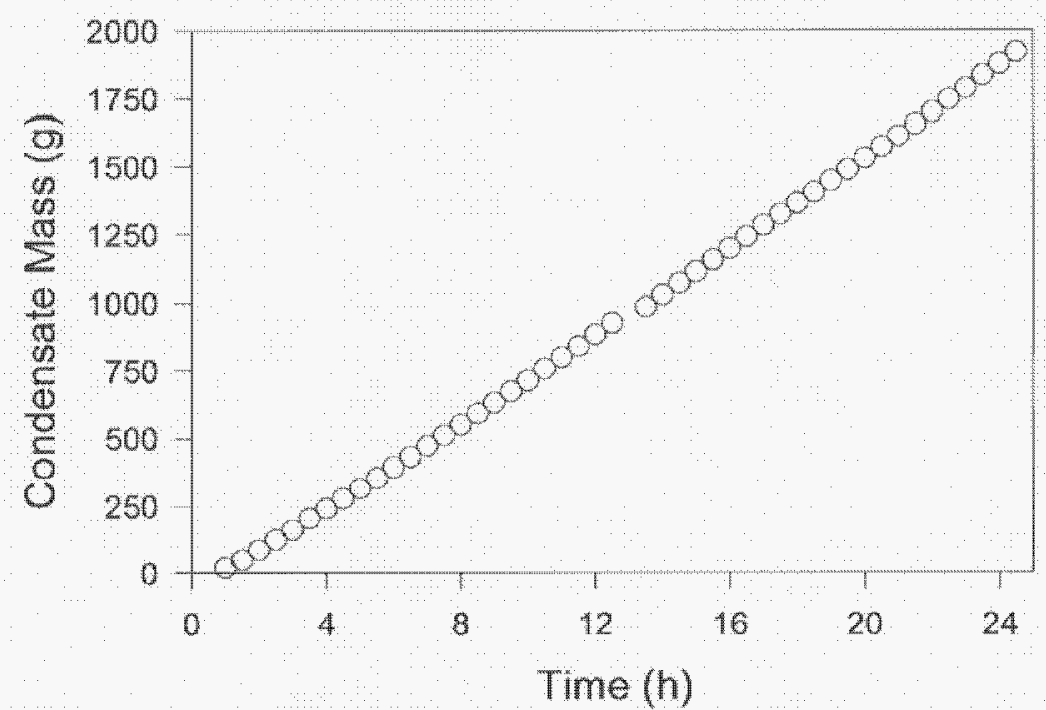

The flowsheet for SST Late (Figure 2-2) shows an optional Stage 2 using the filtrate from Stage 1. In practice, laboratory tests using simulated SST Late feed solutions produced such a small volume of Stage 1 filtrate that Stage 2 was judged impractical on this scale and was not: attempted with the actual tank waste sample.

Figure $2-15$ displays the PLM images of the washed crystals. The left photo shows an overview of the sample. Phases visible in this photo include, in approximate order of abundance:

(1) sodium carbonate monohydrate, (2) sodium nitrate, (3) sodium fluoride phosphate, (4) sodium oxalate, and (5) unidentified tiny particulate. The right photo shows a close-up of the 
Sample with examples of all five phases visible. The large rod-shaped crystal in the upper left (4) is an unusually large erystal of $\mathrm{Na}_{2} \mathrm{C}_{2} \mathrm{O}_{4}$.

Figure 2-15. PLM lmages of Washed Crystals from Run 46.

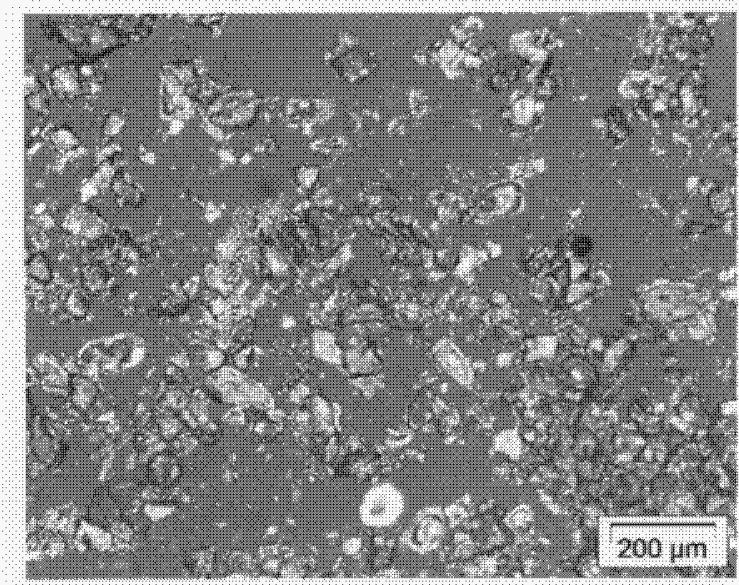

Low-magnification overview.

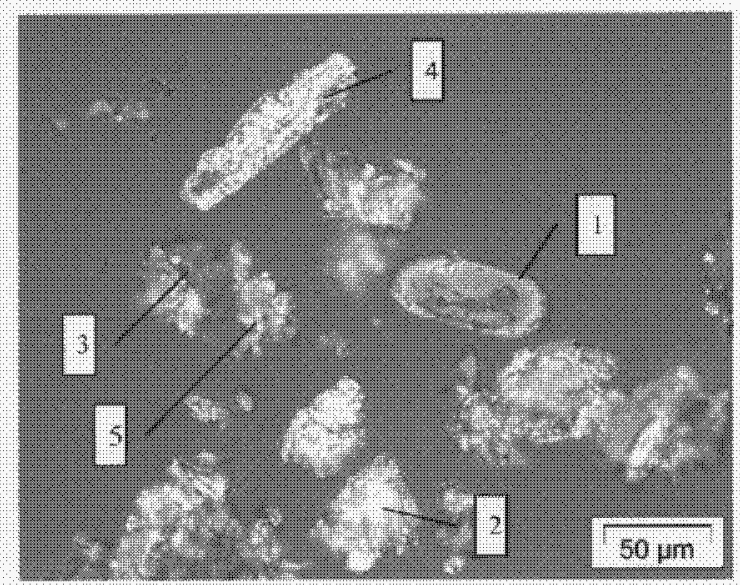

High-magnification close-up.

(callouts described in Section 2.3)

The XRD analysis of this sample gave a spectrum consistent with a mixture of $\mathrm{NaNO}_{3}$ and minor amounts of $\mathrm{Na}_{2} \mathrm{CO}_{3} \cdot \mathrm{H}_{2} \mathrm{O}$. No other phases could be detected by XRD.

The SEM analysis showed the sample to consist primarily of a mixture of $\mathrm{NaNO}_{3}$ and $\mathrm{Na}_{2} \mathrm{CO}_{3} \cdot \mathrm{H}_{2} \mathrm{O}$. Trace amounts of $\mathrm{Na}_{2} \mathrm{C}_{2} \mathrm{O}_{4}$ and $\mathrm{Na}_{7} \mathrm{~F}\left(\mathrm{PO}_{4}\right)_{2} \cdot 19 \mathrm{H}_{2} \mathrm{O}$ (Figure 2-16) were also found.

Figure 2-16. SEM Image and EDS Spectrum of $\mathrm{Na}_{7} \mathrm{~F}\left(\mathrm{PO}_{4}\right)_{2} \cdot 19 \mathrm{H}_{2} \mathrm{O}$ from Run 46 Stage 1.
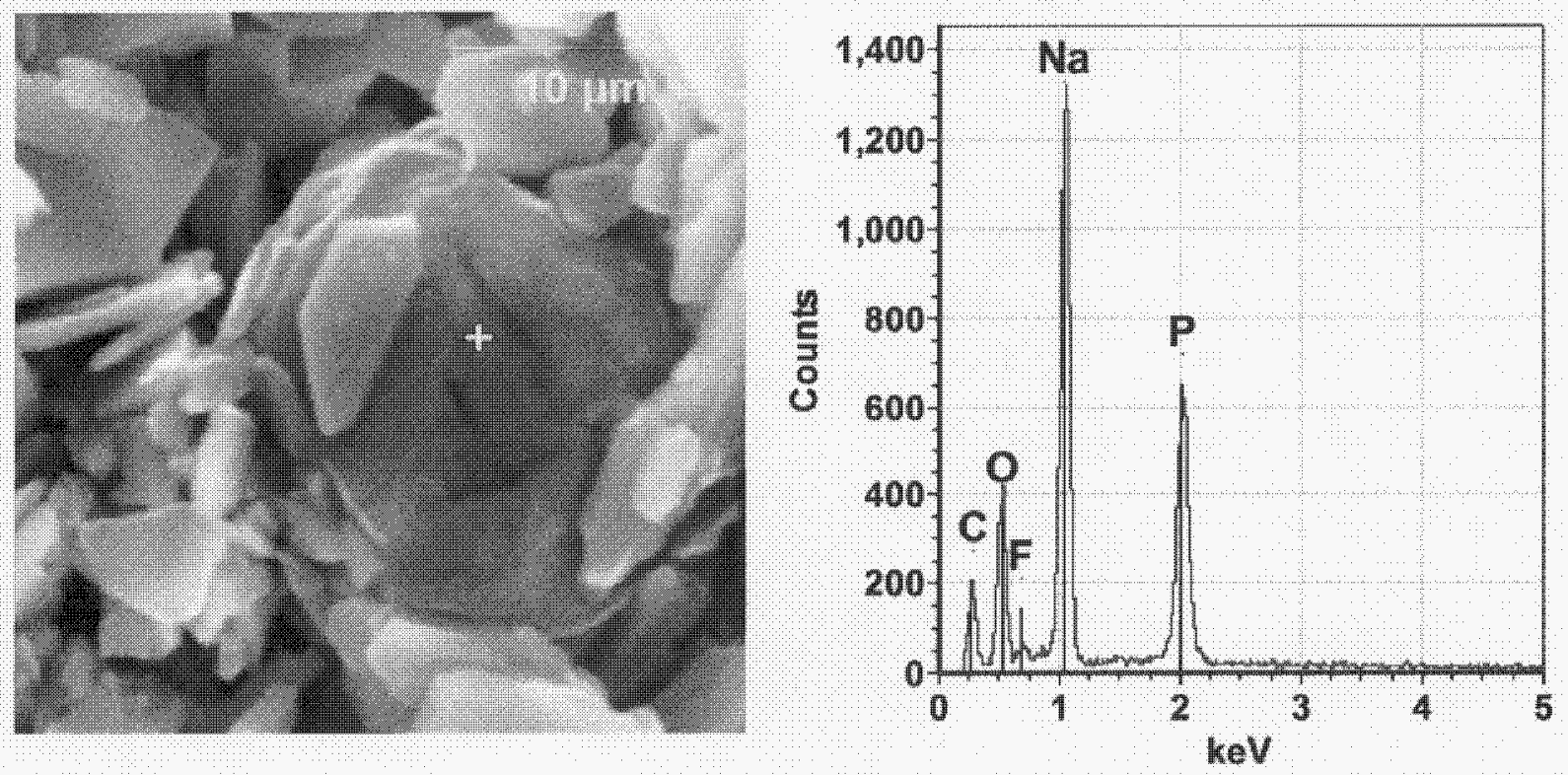


\section{MASS BALANCE}

Mass balance closure for each run was determined by weighing all input and output streams as shown in Figure 3-1 (Run 44 Stage 1), Figure 3-2 (Run 44 Stage 2), and Figure 3-3 (Run 46 Stage 1). The data are also presented for all three runs in Table 3-1.

Input stream weights (feed and wash liquid) were determined by weighing the respective bottles before (full) and after (empty) use. Condensate weight was determined by weighing the condensate receiver flask before (empty) and after (full) the evaporation. Filtrate and spent wash weights were determined by weighing the receiver flask before and after each of the respective filtrations. The weight of washed solids was determined by weighing the sample jar before and after collecting the solids from the filter.

Table 3-1. Mass Balance Closure (stream weights in g).

\begin{tabular}{|c|c|c|c|c|}
\hline & & $\begin{array}{l}\text { Run } 44 \\
\text { Stage } 1 \\
\end{array}$ & $\begin{array}{l}\text { Run } 44 \\
\text { Stage } 2 \\
\end{array}$ & $\begin{array}{l}\text { Run } 46 \\
\text { Stage } 1 \\
\end{array}$ \\
\hline \multirow[t]{3}{*}{ Input } & Feed & $1,321.84$ & 490.84 & $2,194.55$ \\
\hline & Wash liquid & 333.95 & 230.40 & 197.37 \\
\hline & Total & $1,655.79$ & 721.24 & $2,391.92$ \\
\hline \multirow[t]{5}{*}{ Output } & Condensate & 620.17 & 227.51 & $1,926.16$ \\
\hline & Filtrate & 342.08 & 121.77 & 83.12 \\
\hline & Spent wash & 327.60 & 243.14 & 169.47 \\
\hline & Washed solids & 197.34 & 58.22 & 104.16 \\
\hline & Total & $1,487,19$ & 650.64 & $2,282.91$ \\
\hline \multirow[t]{5}{*}{ Measured losses } & Accumulation & 43.54 & 7.88 & 20.43 \\
\hline & \begin{tabular}{|l|} 
Samples \\
\end{tabular} & 8.85 & 10.38 & 7.61 \\
\hline & Beaker residue & 13.04 & 7.98 & 10.92 \\
\hline & Filter residuc & 20.20 & 16.55 & 20.20 \\
\hline & Total & 85.63 & 42.79 & 59.16 \\
\hline \multirow[t]{2}{*}{ Missing mass } & Unaccounted-for loss & 82.97 & 27.81 & 49.85 \\
\hline & $\%$ of input & $5.0 \%$ & $3.9 \%$ & $2.1 \%$ \\
\hline
\end{tabular}

Several known sources of loss could be measured. "Accumulation" was measured by filling the crystallizer with a known weight of water to dissolve the accumulation and then draining and weighing the resulting liquid. This measured weight of accumulation was invariably lower than the calculated weight of accumulation, which was based on the weight of feed minus the weights of condensate and slurry. "Samples" were the aliquots of unwashed and washed solids removed for chemical/radionuclide analysis and PLM. "Beaker residue" represents the amount of slurry that remained in the beaker used to transfer the slurry from the crystallizer to the filter unit and was measured by subtracting the tare weight of the beaker from the "empty" weight of the beaker after the slurry transfer. "Filter residue" is the material not recovered from the filter and was measured by subtracting the tare weight of the filter from the weight of the "dirty" filter at the end of the test.

The "Missing mass" section of Table 3-1 represents the "Input" minus "Output" and "Measured losses." The "Unaccounted-for losses" tend to be higher in these tests than in prior simulated waste tests, which is attributable to the difficulties of working with master-slave manipulators in a hot cell environment. 
RPP-RPT -31352, Rev, 0

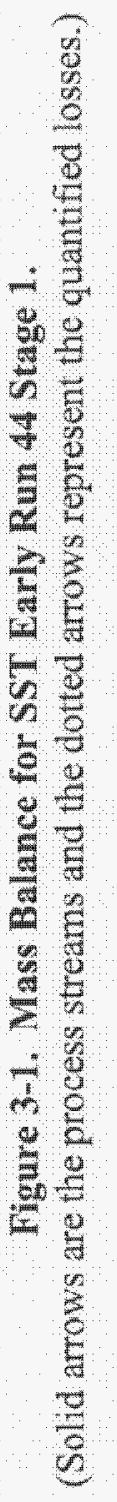
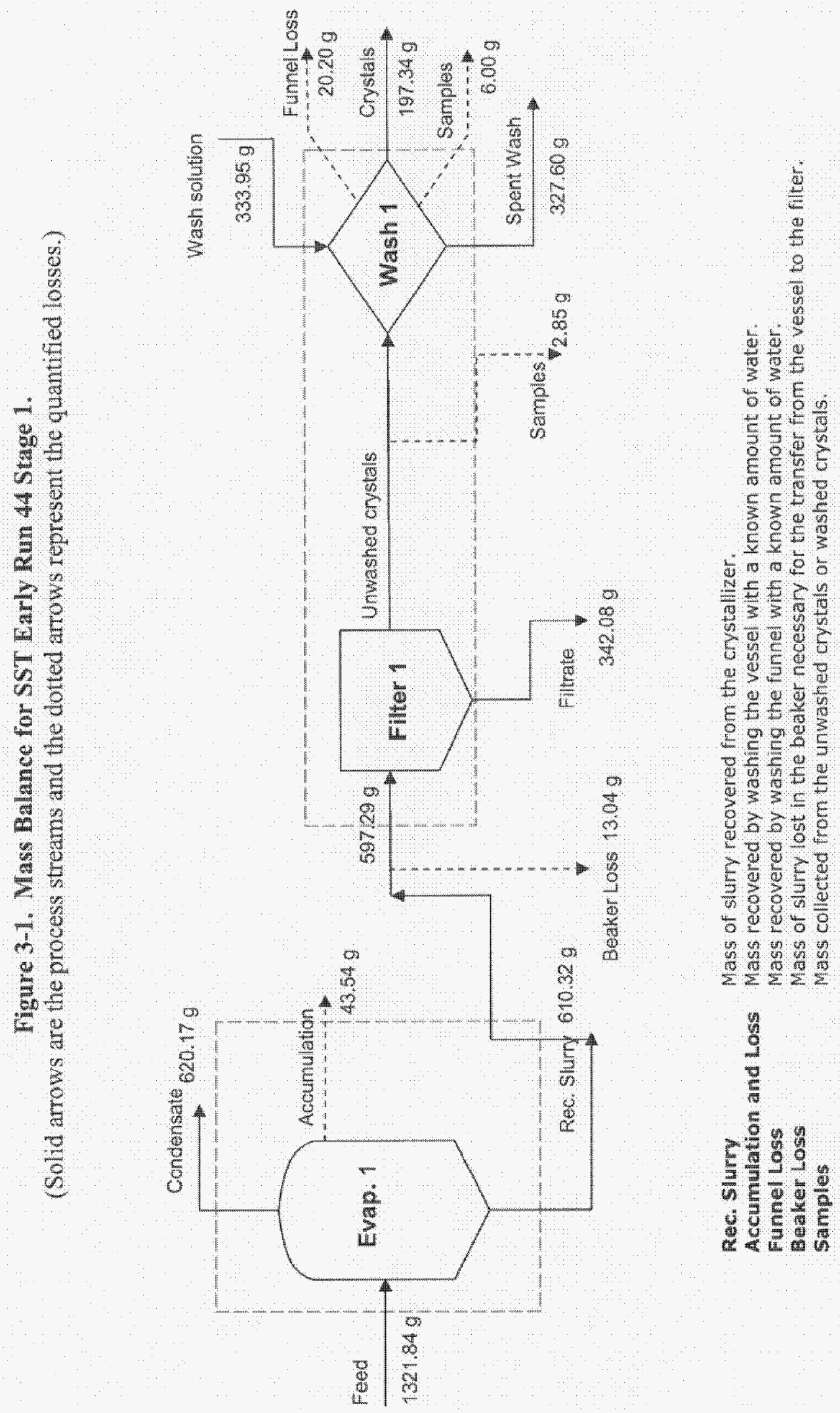

s. 08

$\frac{2}{9} 3 \frac{2}{3}$

$300 \mathrm{~d}$

d 950

5

온온몬용

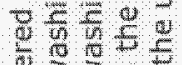

$3 \geq 3 \leq E$

흐응

란?

흥

in on

$\sum \sum \sum \sum \sum$ 
RPP-RPT-31352, Rey 0

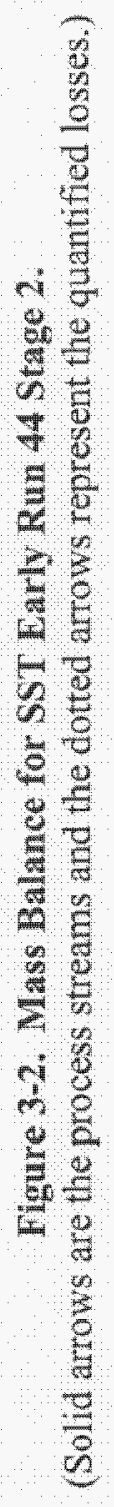
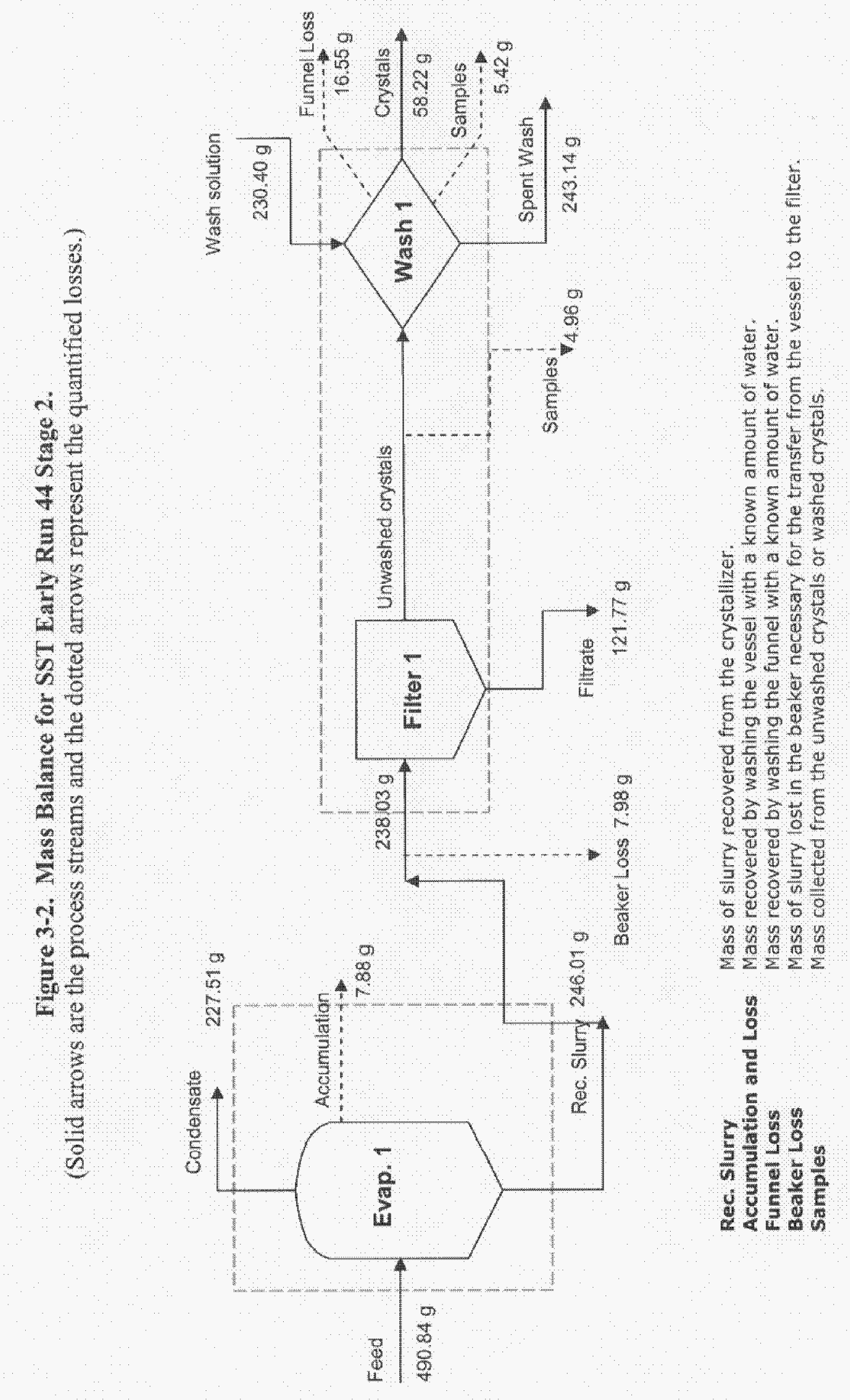

$-1$ 
RPP-RPT-31352, Rev. 0

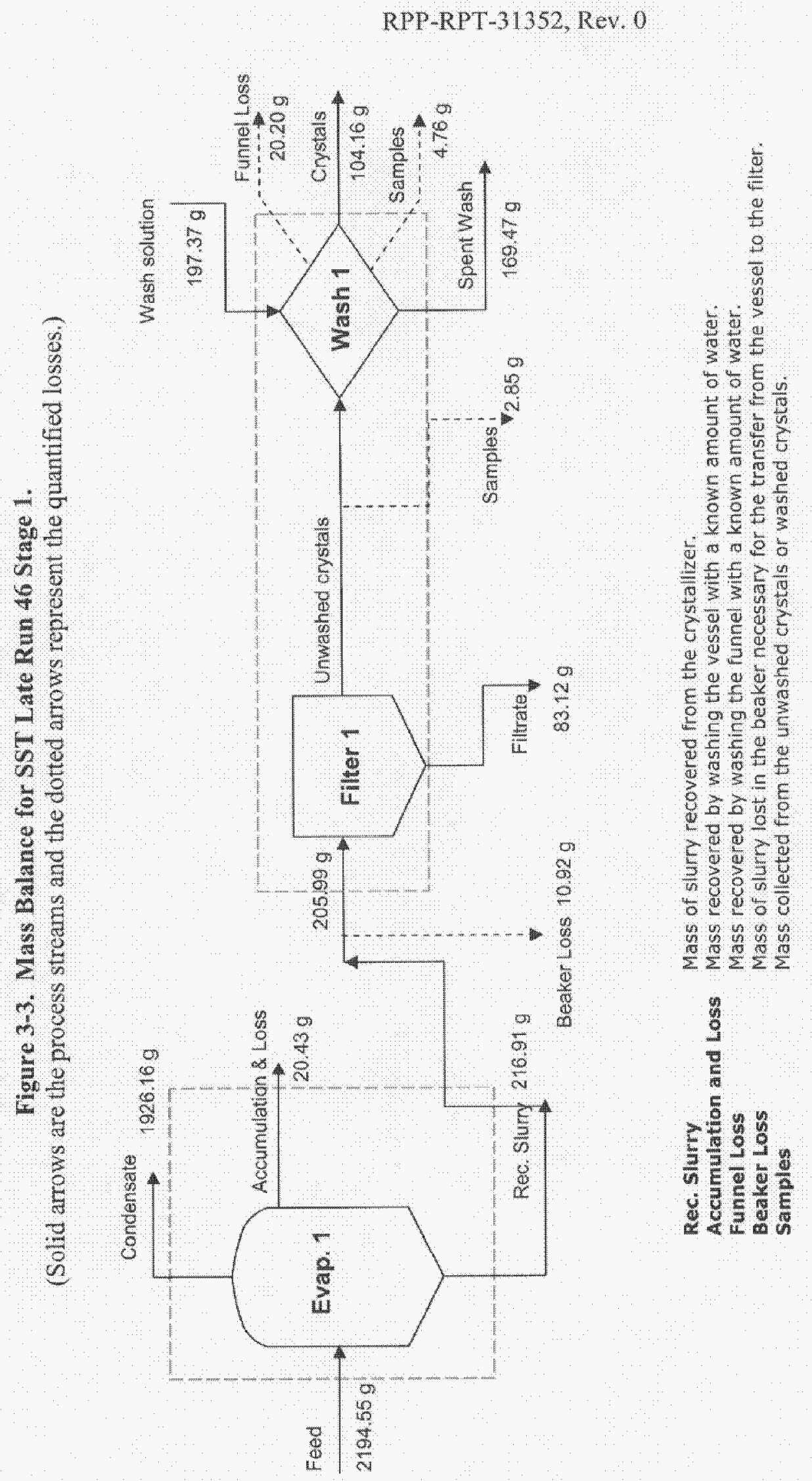




\section{CHEMICAL AND RADIONUCLIDE ANALYSES}

Several sample points in each flowsheet test were submitted for chemical and radionuclide analysis. Washed and unwashed solids samples were prepared by removing $2-4 \mathrm{~g}$ of crystals directly from the filter cake, dissolving them in 30-36 $\mathrm{g}$ of water, and ensuring by observation that all of the solids were dissolved. Filtrate and spent wash liquids were diluted by adding $200 \mathrm{~g}$ water to the filtration receiver flasks prior to the filtrations. The diluted liquids were mixed by shaking the filter flask before aliquots were withdrawn for analysis. The accumulation was dissolved by flooding the crystallizer with water, stirring until all solids dissolved, and then draining the liquid into a receiver and taking an aliquot for analysis.

\subsection{COMPOSITION OF PROCESS STREAMS}

Raw analytical results and dilution factors for all process streams are shown in the Appendix. Dilution-corrected concentrations are shown in Table 4-1 (Run 44 Stage 1), Table 4-2 (Run 44 Stage 2), and Table 4-3 (Run 46 Stage 1). In addition, the chemical compositions of the wash solutions for all three tests, based on known weights of chemicals used to make up the solutions, are shown in Table 4-4.

Table 4-1. Dilution-Corrected Analytical Results for Run 44 Stage 1.

\begin{tabular}{|c|c|c|c|c|c|c|c|}
\hline Analyte & Units & Feed & $\begin{array}{c}\text { Unwashed } \\
\text { Sollds }\end{array}$ & $\begin{array}{l}\text { Washed } \\
\text { Solids }\end{array}$ & Filtrate & $\begin{array}{l}\text { Spent } \\
\text { Wash }\end{array}$ & Accumulation \\
\hline $\mathrm{Al}$ & $w t \%$ & 0.59 & 0.439 & 0.007 & 1.429 & 0.289 & 0.827 \\
\hline $\mathrm{Cr}$ & $\mathbf{w t} \%$ & 0.07 & 0.072 & $<0.003$ & 0.231 & 0.047 & 0.137 \\
\hline $\mathbf{K}$ & $\mathbf{w t} \%$ & 0.05 & $<0.050$ & $<0.055$ & 0.140 & $<0.020$ & $<0.038$ \\
\hline $\mathrm{Na}$ & $\mathbf{w} \%$ & 10.99 & 27.993 & 28.513 & 18.242 & 18.063 & 40.175 \\
\hline $\mathrm{P}$ & $w \%$ & 0.11 & 0.120 & 0.011 & 0.309 & 0.072 & 0.210 \\
\hline s & $w \%$ & 0.33 & 1.393 & 1.124 & 0.091 & 0.078 & 2.116 \\
\hline $\mathbf{S i}$ & $w 1 \%$ & 0.01 & 0.015 & 0.015 & 0.037 & 0.025 & 0.026 \\
\hline $\mathbf{F}$ & $w 1 \%$ & 0.01 & 0.118 & 0.127 & 0.009 & 0.026 & 0.135 \\
\hline $\mathrm{Cl}$ & $w \%$ & 0.20 & 0.137 & $<0.009$ & 0.478 & 0.091 & 0.259 \\
\hline $\mathrm{NO}_{2}$ & $w \%$ & 1.79 & 1.666 & 0.064 & 5.511 & 1.136 & 3.199 \\
\hline $\mathrm{NO}_{3}$ & $w t \%$ & 17.12 & 30.005 & 44.859 & 23.600 & 26.632 & 56.799 \\
\hline $\mathrm{PO}_{4}$ & $w \%$ & 0.33 & 0.329 & $<0.022$ & 0.605 & 0.257 & 0.644 \\
\hline $\mathrm{SO}_{4}$ & $w 1 \%$ & 0.93 & 4.023 & 3.176 & 0.245 & 0.220 & 6.234 \\
\hline Oxalate & $w \%$ & 0.04 & 0.206 & 0.103 & 0.029 & 0.032 & 0.344 \\
\hline TIC & $w 1 \%$ & 0.56 & 3.034 & 2.173 & 0.191 & 0.243 & 2.733 \\
\hline TOC & $w t \%$ & 0.08 & 0.125 & 0.041 & 0.126 & 0.035 & 0.175 \\
\hline OlI & $w 1 \%$ & 0.80 & 0.739 & 0.028 & 2.444 & 4.219 & 1.419 \\
\hline${ }^{92} \mathrm{Tc}$ & $\mu \mathrm{g} / \mathrm{g}$ & 2.78 & 2.60 & 0.04 & 8.48 & 1.70 & 4.81 \\
\hline${ }^{137} \mathrm{Cs}$ & $\mu \mathrm{Ci} / g$ & 45.4 & 43.4 & 0.76 & 139 & 28.6 & 80.3 \\
\hline${ }^{50} \mathrm{Sr}$ & $\mu \mathrm{Ci} / \mathrm{g}$ & 0.045 & 0.074 & 0.078 & 0.007 & 0.005 & 0.125 \\
\hline 1291 & $\mu \mathrm{Ci} / g$ & $4.2 \mathrm{E}-05$ & $<4.2 \mathrm{E}-04$ & $<1,8 \mathrm{E}-04$ & $1.4 \mathrm{E}-04$ & $2.8 \mathrm{E}-05$ & 5.5E-05 \\
\hline Total mass & $g$ & $1,321.8$ & 255.2 & 226.4 & 342.1 & 327.6 & 43.5 \\
\hline
\end{tabular}

TIC $=$ total inorganic carbon

TOC = total organic carbon

Compare the concentrations in the washed and unwashed solids in Table 4-1. Notice how components that are present only in the ISL are much higher in the unwashed solids $(\mathrm{Al}, \mathrm{Cr}, \mathrm{Cl}$, 


\section{RPP-RPT-31352, Rev, 0}

$\mathrm{NO}_{2}, \mathrm{PO}_{4}, \mathrm{OH},{ }^{99} \mathrm{Tc},{ }^{137} \mathrm{Cs}$, and $\left.{ }^{129} \mathrm{I}\right)$. Components that are present in the solid phase are close to the same concentration in the washed and unwashed solids $\left[\mathrm{Na}, \mathrm{F}, \mathrm{NO}_{3}, \mathrm{~S} / \mathrm{SO}_{4}\right.$, total inorganic carbon (TIC), oxalate, $\left.{ }^{90} \mathrm{Sr}\right]$.

Compare the unwashed solids and accumulation columns in Table 4-1. Note that the accumulation values are nearly twice as high in almost all cases-liquid phase and solid phase components alike. It is also noteworthy that the accumulation values are impossibly high, i.e., the sum of the components totals much more than $100 \mathrm{wt} \%$, leading to the conclusion that there is an error in the dilution factor for that sample. As discussed in Section 3, the measured weight of accumulation was invariably lower than the amount calculated by difference. In the case of this sample, if the calculated weight of accumulation $(91.35 \mathrm{~g})$ were substituted for the measured weight $(43.54 \mathrm{~g})$, the resulting concentrations would be nearly equal to those of the unwashed solids. Therefore, it is clear that the composition of the accumulation closely resembles that of the unwashed solids.

\subsection{PHIASES PRESENT IN WASHED SOLIDS}

The weight percent of each compound present in the washed solids can be found by multiplying the anion weight percent in Table 4-1 by the ratio of the compound molecular weight to the anion formula weight. For example

$$
\mathrm{Wt} \% \mathrm{NaNO}_{3}=(44.86 \%) *(85.0 / 62.0)=61.5 \%
$$

In this manner, the washed solids are found to be composed of the following:

a. $61.5 \% \mathrm{NaNO}_{3}$.

b. $19.2 \% \mathrm{Na}_{2} \mathrm{CO}_{3}$ [present as $\mathrm{Na}_{2} \mathrm{CO}_{3} \cdot \mathrm{H}_{2} \mathrm{O}$ and as $\mathrm{Na}_{6} \mathrm{CO}_{3}\left(\mathrm{SO}_{4}\right)_{2}$ ].

c. $4.7 \% \mathrm{Na}_{2} \mathrm{SO}_{4}$ [present as $\mathrm{Na}_{6} \mathrm{CO}_{3}\left(\mathrm{SO}_{4}\right)$ ] .

d. $0.3 \% \mathrm{NaF}$ (likely present as $\mathrm{Na}_{3} \mathrm{FSO}_{4}$, but not verified).

(Note that these weights do not total $100 \%$ due to analytical uncertainties and waters of hydration.)

The same general observations pointed out for Table 4-1 also apply to Table 4-2 except that phosphate and sulfate exchanged places, i.e., sulfate appears in the list of solid phase components in Table 4-1 but in the list of liquid phase components in Table 4-2, and vice versa for phosphate. The same dilution-factor error for the accumulation also applies due to the discrepancy between measured $(7.88 \mathrm{~g})$ and calculated $(17.32 \mathrm{~g})$ weights of accumulation.

The washed solids in Table 4-2 are composed of the following:
a. $88.9 \% \mathrm{NaNO}_{3}$.
b. $4.1 \% \mathrm{Na}_{2} \mathrm{CO}_{3}$ (present as $\mathrm{Na}_{2} \mathrm{CO}_{3} \cdot \mathrm{H}_{2} \mathrm{O}$ ).
c. $0.7 \% \mathrm{Na}_{3} \mathrm{PO}_{4}$.
d. $0.1 \% \mathrm{NaF}$ [present as $\mathrm{Na}_{7} \mathrm{~F}\left(\mathrm{PO}_{4}\right)_{2} \cdot 19 \mathrm{H}_{2} \mathrm{O}$ ]. 
RPP-RPT-31352, Rev. 0

Table 4-2. Dilution-Corrected Analytical Results for Run 44 Stage 2.

\begin{tabular}{|c|c|c|c|c|c|c|c|}
\hline Analyte & Untes & Feed & $\begin{array}{c}\text { Unwashed } \\
\text { Solids }\end{array}$ & $\begin{array}{l}\text { Washed } \\
\text { Solids }\end{array}$ & Filtrate & $\begin{array}{l}\text { Spent } \\
\text { Wash }\end{array}$ & Accumulatlon \\
\hline Al & wt\% & 1.43 & 0.977 & 0.008 & 2.432 & 0.439 & 2.672 \\
\hline $\mathrm{Cr}$ & $w t \%$ & 0.23 & 0.160 & $<0.001$ & 0.388 & 0.071 & 0.429 \\
\hline $\bar{K}$ & $w t \%$ & 0.14 & 0.078 & $<0.025$ & 0.207 & $<0.023$ & 0.210 \\
\hline $\mathrm{Na}$ & $\mathbf{w t} \%$ & 18.24 & 23,852 & 25.728 & 20.041 & 17.667 & 36.661 \\
\hline $\mathbf{P}$ & $w t \%$ & 0.31 & 0.520 & 0.116 & 0.306 & 0.189 & 0.761 \\
\hline S & $w t \%$ & 0.09 & 0.059 & $<0.005$ & 0.149 & 0.027 & 0.177 \\
\hline$\overline{\mathrm{Si}}$ & $\mathbf{w} t \%$ & 0.04 & 0.028 & 0.017 & 0.068 & 0.031 & 0.086 \\
\hline $\mathbf{F}$ & $w t \%$ & 0.01 & 0.028 & 0.033 & 0.002 & 0.004 & 0.031 \\
\hline $\mathrm{Cl}$ & wt\% & 0.48 & 0.315 & $<0.007$ & 0.786 & 0.148 & 0.848 \\
\hline $\mathrm{NO}_{2}$ & $w^{t} \%$ & 5.51 & 3.972 & 0.084 & 9.634 & 1.798 & 10.335 \\
\hline $\mathrm{NO}_{3}$ & $w t \%$ & 23.60 & 41.247 & 64.854 & 13.002 & 20.012 & 49.239 \\
\hline $\mathrm{PO}_{4}$ & $w t \%$ & 0.60 & 1.641 & 0.427 & 0.910 & 0.624 & 2.243 \\
\hline SO & $w \%$ & 0.24 & 0.163 & $<0.058$ & 0.379 & 0.074 & 0.454 \\
\hline Oxalate & $\mathbf{w} \%$ & 0.03 & $<0.048$ & $<0.044$ & 0.049 & $<0.008$ & $<0.258$ \\
\hline TIC & wt\% & 0.19 & 0.321 & 0.459 & 0.152 & 0.286 & 0.507 \\
\hline TOC & $\mathrm{wt} \%$ & 0.13 & 0.097 & $<0.066$ & 0.205 & 0.044 & 0.093 \\
\hline OH & $w t \%$ & 2.44 & 1.762 & 0.037 & 4.583 & 5.316 & 4.583 \\
\hline Tc & $\mu \mathrm{g} / \mathrm{g}$ & 8.48 & 5.63 & 0.04 & 13.84 & 2.56 & 15.45 \\
\hline${ }^{137} \mathrm{Cs}$ & $\mu \mathrm{Ci} / \mathrm{g}$ & 139 & 93.3 & 0.62 & 232 & 41.9 & 254 \\
\hline${ }^{90} \mathrm{Sr}$ & $\mu \mathrm{Ci} / \mathrm{g}$ & 0.01 & 0.00065 & 0.00082 & 0.00828 & 0.00245 & $<0.0014$ \\
\hline 120 & $u \mathrm{Ci} / \mathrm{g}$ & $14 \mathrm{E}-04$ & $5.9 \mathrm{E}-05$ & $<1.6 \mathrm{E}-04$ & $2.1 \mathrm{E}-04$ & $3.9 \mathrm{E}-05$ & $2.1 \mathrm{E}-04$ \\
\hline Total mass & g & 311.4 & 116.3 & 85.2 & 121.8 & 243.1 & 7.9 \\
\hline
\end{tabular}

In Table 4-3, both sulfate and phosphate are present in the solid phase, as evidenced by the comparison between the washed and unwashed solids. The apparent dilution-factor error in the accumulation is present again, with measured and calculated weights of accumulation of $20.43 \mathrm{~g}$ and $51.48 \mathrm{~g}$, respectively.

The washed solids in Table 4-3 are composed of the following:
a. $43.7 \%$ NaNO3.
b. $13.2 \% \mathrm{Na}_{2} \mathrm{CO}_{3}$ [present as $\mathrm{Na}_{2} \mathrm{CO}_{3} \cdot \mathrm{H}_{2} \mathrm{O}$ and as $\mathrm{Na}_{6} \mathrm{CO}_{3}\left(\mathrm{SO}_{4}\right)_{2}$ ].
c. $8.3 \% \mathrm{Na}_{2} \mathrm{C}_{2} \mathrm{O}_{4}$.
d. $4.4 \% \mathrm{Na}_{3} \mathrm{PO}_{4}$ [present as $\mathrm{Na}_{7} \mathrm{~F}\left(\mathrm{PO}_{4}\right)_{2} \cdot 19 \mathrm{H}_{2} \mathrm{O}$ ].
c. $3.8 \% \mathrm{Na}_{2} \mathrm{SO}_{4}$ [present as $\mathrm{Na}_{6} \mathrm{CO}_{3}\left(\mathrm{SO}_{4}\right)_{2}$ and likely $\mathrm{Na}_{3} \mathrm{FSO}_{4}$ ].
f. $2.5 \% \mathrm{NaF}$ (likely present as both phosphate and sulfate double salts).

Note in Table 4.3 that approximately all of the total organic carbon (TOC) in the SST Late washed solids is accounted for by oxalate, i.e.

$$
(5.44 \mathrm{wt} \% \mathrm{C} 2 \mathrm{O} 4) *(24.0 \mathrm{~g} \mathrm{TOC} / 88.0 \mathrm{~g} \mathrm{C} 2 \mathrm{O} 4)=1.48 \mathrm{wt} \% \mathrm{TOC} \text {, }
$$

compared to the table value of 1.53 wt $\%$ TOC. 
RPP-RPT-31352, Rev. 0

Table 4-3. Dilution-Corrected Analytical Results for Run 46 Stage 1.

\begin{tabular}{|c|c|c|c|c|c|c|c|}
\hline Analyte & Units & Feed & $\begin{array}{l}\text { Unwashed } \\
\text { Sollds }\end{array}$ & $\begin{array}{l}\text { Washed } \\
\text { Solids }\end{array}$ & Filtrate & $\begin{array}{l}\text { Spent } \\
\text { Wash }\end{array}$ & Accumulation \\
\hline$\overline{A !}$ & $w t \%$ & 0.10 & 0.29 & 0.02 & 1.56 & 0.26 & 1.02 \\
\hline$\overline{\mathrm{Cr}}$ & $\mathbf{w} \%$ & 0.01 & 0.055 & 0.006 & 0.273 & 0.046 & 0.182 \\
\hline$\overline{\mathbf{K}}$ & $w \%$ & 0.01 & $<0.03$ & $<0.03$ & 0.13 & $<0.02$ & 0.05 \\
\hline $\mathrm{Na}$ & $w \%$ & 2.61 & 27.85 & 26.51 & 17.56 & 17.13 & 29.00 \\
\hline $\mathbf{P}$ & $w 1 \%$ & 0.07 & 1.10 & 0.83 & 0.09 & 0.10 & 0.83 \\
\hline $\bar{S}$ & $w t \%$ & 0.07 & 1.04 & 0.91 & 0.022 & 0.020 & 0.93 \\
\hline $\mathrm{Si}$ & $\mathbf{w t} \%$ & 0.01 & 0.027 & 0.013 & 0.056 & 0.026 & 0.056 \\
\hline $\bar{F}$ & $\mathbf{w}+\%$ & 0.09 & 1.27 & 1.12 & 0.10 & 0.08 & 1.25 \\
\hline $\mathbf{C l}$ & $w t \%$ & 0.04 & 0.08 & $<0.01$ & 0.47 & 0.08 & $\overline{0.30}$ \\
\hline $\mathrm{NO}_{2}$ & $w t \%$ & 0.31 & 0.97 & 0.07 & 5.81 & 0.92 & 3.59 \\
\hline $\mathrm{NO}_{3}$ & $w t \%$ & 3.10 & 32.15 & 31.88 & 22.65 & 27.22 & 31.93 \\
\hline $\mathrm{PO}_{4}$ & $w t \%$ & 0.22 & 2.94 & 2.54 & 0.27 & 0.34 & 2.27 \\
\hline $\mathrm{SO}_{4}$ & $w t \%$ & 0.19 & 2.74 & 2.55 & 0.03 & 0.05 & 2.65 \\
\hline Oxalate & $w t \%$ & 0.45 & 5.82 & 5.44 & 0.02 & 0.02 & 5.87 \\
\hline TIC & $w t \%$ & 0.11 & 1.55 & 1.49 & 0.21 & 0.30 & 1.29 \\
\hline TOC & $w \%$ & 0.12 & $1.7 !$ & 1.53 & 0.13 & 0.03 & 1.66 \\
\hline OHI & $w 2 \%$ & 0.16 & 0.50 & 0.04 & 2.57 & 3.40 & 1.87 \\
\hline "Tc & $\overline{\mu g} / \mathrm{g}$ & 0.567 & 1.743 & 0.089 & 8.718 & 1.469 & 5.574 \\
\hline${ }^{\mathrm{T}} \mathrm{C} \mathrm{Cs}$ & $\mu \mathrm{Ci} / \mathrm{g}$ & 8.87 & 26.04 & 1.19 & 139.37 & 23.63 & 91.39 \\
\hline${ }^{90} \mathrm{Sr}$ & $\mu \mathrm{Ci} / \mathrm{g}$ & 0.008 & 0.017 & 0.018 & 0.006 & 0.004 & 0.030 \\
\hline $720 \mathrm{I}$ & $\mu \mathrm{Ci} / \mathrm{g}$ & $6.5 \mathrm{E}-06$ & $<4.3 \mathrm{E}-04$ & $<1.9 \mathrm{E}-04$ & $1.3 E_{-04}$ & $2.3 \mathrm{E}-05$ & $6.7 \mathrm{E}-05$ \\
\hline Total mass & $\mathrm{g}$ & $2,194.6$ & 122.9 & 132.0 & 83.1 & 169.5 & 20.4 \\
\hline
\end{tabular}

Table 4-4. Composition of Wash Llquids (weights in g).

\begin{tabular}{|l|c|c|c|}
\hline \multicolumn{1}{|c|}{ Chemical } & $\begin{array}{c}\text { Run 44 } \\
\text { Stage 1 }\end{array}$ & $\begin{array}{c}\text { Run 44 } \\
\text { Stage 2 }\end{array}$ & $\begin{array}{c}\text { Run 46 } \\
\text { Stage 1 }\end{array}$ \\
\hline $\mathrm{II}_{2} \mathrm{O}$ & 242.3 & 157.8 & 123.0 \\
\hline $\mathrm{NaOII}$ & 38.7 & 35.5 & 18.5 \\
\hline $\mathrm{NaNO}_{3}$ & 197.4 & 85.6 & 84.1 \\
\hline $\mathrm{Na}_{2} \mathrm{CO}_{3}$ & 24.7 & 8.9 & 12.7 \\
\hline $\mathrm{NaF}$ & 0.5 & 0.0 & 0.2 \\
\hline
\end{tabular}

\subsection{SPECIES MASS BALANCE}

The dilution-corrected analytical results in Tables 4-1 through 4-3 can be multiplied by the total mass to find the total number of grams of each analyte (or $\mu \mathrm{g}$ of ${ }^{99} \mathrm{Tc}$ or $\mu \mathrm{Ci}$ of other radionuclides) in each process stream. These results are shown in Tables 4-5 through 4-7.

Most of the analytes in Table 4-5 show good recovery (close to 100\%). The most glaring exceptions are those that are close to or below detection limits in some of the samples $(\mathrm{K}, \mathrm{Si}, \mathrm{F})$, and ${ }^{90} \mathrm{Sr}$, which suffered from poor recovery in all three runs. 
Table 4-5. Species Mass Balance, Run 44 Stage 1.

[Input and output amounts in $\mathrm{g}, \mu \mathrm{g}\left({ }^{99} \mathrm{Tc}\right)$, or $\mu \mathrm{Ci}$ (other isotopes)]

\begin{tabular}{|c|c|c|c|c|c|c|c|c|c|}
\hline \multirow[b]{2}{*}{ Analyte } & \multicolumn{3}{|c|}{ Input } & \multicolumn{5}{|c|}{ Oulput } & \multirow[b]{2}{*}{$\% \operatorname{Rec}$} \\
\hline & Feed & $\begin{array}{c}\text { Wash } \\
\text { Liquild" }\end{array}$ & Total & Filtrate & $\begin{array}{l}\text { Spent } \\
\text { Wash }\end{array}$ & Accumulation & $\begin{array}{l}\text { Washed } \\
\text { Solids }\end{array}$ & Total & \\
\hline $\mathrm{Al}$ & 7.81 & & 7.81 & 4.89 & 0.95 & 0.36 & 0.02 & 6.21 & 79 \\
\hline $\mathrm{Cr}$ & 0.99 & & 0.99 & 0.79 & 0.15 & 0.06 & $<$ det & 1.00 & 101 \\
\hline $\mathbf{K}$ & 0.70 & & 0.70 & 0.48 & $<\operatorname{det}$ & $<\operatorname{det}$ & $<$ det & 0.48 & 68 \\
\hline $\mathbf{N a}$ & 145.3 & 57.5 & 202.78 & 62.40 & 59.17 & 17.49 & 64.55 & 203.62 & 100 \\
\hline $\mathbf{P}$ & 1.43 & & 1.43 & 1.06 & 0.24 & 0.09 & 0.02 & 1.41 & 99 \\
\hline $\mathbf{S}$ & 4.42 & & 4.42 & 0.31 & 0.25 & 0.92 & 2.54 & 4.03 & 91 \\
\hline$\overline{\mathrm{Si}}$ & 0.17 & & 0.17 & 0.13 & 0.08 & 0.01 & 0.03 & 0.25 & 150 \\
\hline $\mathbf{F}$ & 0.19 & 0.15 & 0.34 & 0.03 & 0.09 & 0.06 & 0.29 & 0.46 & 136 \\
\hline $\mathrm{Cl}$ & 2.59 & & 2.59 & 1.64 & 0.30 & 0.11 & $<$ det & 2.05 & 79 \\
\hline $\mathrm{NO}_{2}$ & 23.7 & & 23.72 & 18.85 & 3.72 & 1.39 & 0.14 & 24.11 & 102 \\
\hline $\mathrm{NO}_{3}$ & 226.4 & 95.5 & 321.84 & 80.73 & 87.25 & 24.73 & 101.56 & 294.27 & 91 \\
\hline $\mathrm{PO}_{4}$ & 4.38 & & 4.38 & 2.07 & 0.84 & 0.28 & $<$ det & 3.19 & 73 \\
\hline $\mathrm{SO}_{4}$ & 12.31 & & 12.31 & 0.84 & 0.72 & 2.71 & 7.19 & 11.46 & 93 \\
\hline Oxalatc & 0.53 & & 0.53 & 0.10 & 0.10 & 0.15 & 0.23 & 0.59 & 111 \\
\hline TIC & 7.38 & 1.85 & 9.23 & 0.65 & 0.79 & 1.19 & 4.92 & 7.56 & 82 \\
\hline TOC & 1.00 & & 1.00 & 0.43 & 0.11 & 0.08 & 0.09 & 0.71 & 71 \\
\hline OII & 10.5 & 10.9 & 21.43 & 8.36 & 13.82 & 0.62 & 0.06 & 22.86 & 107 \\
\hline${ }^{99} \mathrm{Tc}$ & 3,675 & & 3,675 & 2902 & 557 & 209 & 8.0 & 3,677 & 100 \\
\hline${ }^{157} \mathrm{Cs}$ & 59,983 & & 59,983 & 47,566 & 9,373 & 3,498 & 173 & 60,610 & 101 \\
\hline${ }^{90} \mathrm{Sr}$ & 60.1 & & 60.1 & 2.5 & 1.7 & 5.4 & 17.6 & 27.4 & 46 \\
\hline${ }^{129}$ I & 0.055 & & 0.055 & 0.047 & 0.009 & 0.002 & $<$ det & 0.059 & 106 \\
\hline
\end{tabular}

"Wash liquid values are based on known weights of chemicals used to prepare the wash liquid, not on sample analysis.

Table 4-6. Species Mass Balance, Run 44 Stage 2.

[Input and output amounts in $\mathrm{g}, \mu \mathrm{g}\left({ }^{99} \mathrm{Tc}\right)$, or $\mu \mathrm{Ci}$ (other isotopes)]

\begin{tabular}{|c|c|c|c|c|c|c|c|c|c|}
\hline \multirow[b]{2}{*}{ Analyte } & \multicolumn{3}{|c|}{ Input } & \multicolumn{5}{|c|}{ Output } & \multirow[b]{2}{*}{$\%$ Ree } \\
\hline & Feed & $\begin{array}{c}\text { Wash } \\
\text { Liquid" }\end{array}$ & Total & Filtrate & $\begin{array}{l}\text { Spent } \\
\text { Wash }\end{array}$ & Accum & $\begin{array}{c}\text { Washed } \\
\text { Solids }\end{array}$ & Total & \\
\hline $\mathrm{Al}$ & 4.45 & & 4.45 & 2.96 & 1.07 & 0.21 & 0.01 & 4.25 & 95 \\
\hline $\mathrm{Cr}$ & 0.72 & & 0.72 & 0.47 & 0.17 & 0.03 & 0.00 & 0.68 & 94 \\
\hline $\mathrm{K}$ & 0.44 & & 0.44 & 0.25 & $<\mathrm{det}$ & 0.02 & $<\mathrm{det}$ & 0.27 & 62 \\
\hline $\mathrm{Na}$ & 56.80 & $\overline{37.98}$ & 94.78 & 24.40 & 42.96 & 2.89 & 21.91 & 92.16 & 97 \\
\hline $\mathbf{P}$ & 0.96 & & 0.96 & 0.37 & 0.46 & 0.06 & 0.10 & 0.99 & 103 \\
\hline $\bar{s}$ & 0.28 & & 0.28 & 0.18 & 0.07 & 0.01 & 0.00 & 0.26 & 91 \\
\hline $\mathbf{S i}$ & 0.11 & & 0.11 & 0.08 & 0.07 & 0.01 & 0.01 & 0.18 & 156 \\
\hline $\mathbf{F}$ & 0.03 & & 0.03 & 0.00 & 0.01 & 0.00 & 0.03 & 0.04 & 150 \\
\hline $\mathrm{Cl}$ & 1.49 & & 1.49 & 0.96 & 0.36 & 0.07 & $<$ det & 1.38 & 93 \\
\hline $\mathrm{NO}_{2}$ & 17.16 & & 17.16 & 11.73 & 4.37 & 0.81 & 0.07 & 16.99 & 99 \\
\hline $\mathrm{NO}_{3}$ & 73.48 & 49.98 & 123.47 & 15.83 & 48.66 & 3.88 & 55.22 & 123.59 & 100 \\
\hline $\mathrm{PO}_{4}$ & 1.88 & & 1.88 & 1.11 & 1.52 & 0.18 & 0.36 & 3.16 & 168 \\
\hline $\mathrm{SO}_{4}$ & 0.76 & & 0.76 & 0.46 & 0.18 & 0.04 & $<\mathrm{det}$ & 0.68 & 89 \\
\hline Oxalate & 0.09 & & 0.09 & 0.06 & $<$ det & $<$ det & $<$ det & 0.06 & 66 \\
\hline TIC & 0.60 & 0.81 & 1.40 & 0.19 & 0.70 & 0.04 & 0.39 & 1.31 & 94 \\
\hline TOC & 0.39 & & 0.39 & 0.25 & 0.11 & 0.01 & $<$ det & 0.36 & 93 \\
\hline OH & 7.61 & 12.08 & 19.69 & 5.58 & 12.92 & 0.36 & 0.03 & 18.90 & 96 \\
\hline${ }^{92} \mathrm{TC}$ & 2,641 & & 2,641 & 1,686 & 623 & 122 & 3 & 2,434 & 92 \\
\hline${ }^{\mathrm{T} T} \mathrm{Cs}$ & 43,296 & & 43,296 & 28,191 & 10,188 & 1,998 & 52 & 40,428 & 93 \\
\hline${ }^{90} \mathrm{ST}$ & 2.29 & & 2.29 & 1.01 & 0.60 & $<$ det & 0.07 & 1.67 & 73 \\
\hline 729 & 0.043 & & 0.043 & 0.026 & 0.010 & 0.002 & $<$ det & 0.037 & 86 \\
\hline
\end{tabular}

${ }^{\text {a }}$ Wash liquid values are based on known weights of chemicals used to prepare the wash liquid, not on sample analysis. 
RPP-RPT-31352, Rev. 0

Table 4-7. Specics Mass Balance, Run 46 Stage 1.

[Input and output amounts in $\mathrm{g}, \mu \mathrm{g}\left({ }^{99} \mathrm{Tc}\right)$, or $\mu \mathrm{Ci}$ (other isotopes)]

\begin{tabular}{|c|c|c|c|c|c|c|c|c|c|}
\hline \multirow[b]{2}{*}{ Analyte } & \multicolumn{3}{|c|}{ Input } & \multicolumn{5}{|c|}{ Outpat } & \multirow[b]{2}{*}{$\% \operatorname{Rec}$} \\
\hline & Feed & $\begin{array}{l}\text { Wash } \\
\text { Liquid" }\end{array}$ & Total & Filtrate & $\begin{array}{l}\text { Spent } \\
\text { Wash }\end{array}$ & Accumulation & $\begin{array}{l}\text { Washed } \\
\text { Sollds }\end{array}$ & Total & \\
\hline$\overline{\mathrm{Al}}$ & 2.18 & & 2.18 & 1.30 & 0.45 & 0.21 & 0.02 & 1.97 & 90 \\
\hline $\mathrm{Cr}$ & 0.32 & & 0.32 & 0.23 & 0.08 & 0.04 & 0.01 & 0.35 & 108 \\
\hline $\bar{K}$ & 0.24 & & 0.24 & 0.11 & $\leq \mathrm{det}$ & 0.01 & $<$ det & 0.12 & 48 \\
\hline $\mathrm{Na}$ & 57.19 & 32.29 & 89.48 & 14.60 & 29.02 & 5.92 & 34.98 & 84.53 & 94 \\
\hline $\mathbf{P}$ & 1.60 & & 1.60 & 0.08 & 0.17 & 0.17 & 1.10 & 1.52 & 95 \\
\hline $\mathbf{S}$ & 1.52 & & 1.52 & 0.02 & 0.03 & 0.19 & 1.20 & 1.44 & 95 \\
\hline$\overline{S i}$ & 0.12 & & 0.12 & 0.05 & 0.04 & 0.01 & 0.02 & 0.12 & 102 \\
\hline $\mathbf{F}$ & 2.05 & 0.07 & 2.12 & 0.08 & 0.14 & 0.26 & 1.47 & 1.95 & 92 \\
\hline $\mathrm{Cl}$ & 0.95 & & 0.95 & 0.39 & 0.13 & 0.06 & $<$ det & 0.59 & 62 \\
\hline $\mathrm{NO}_{2}$ & 6.76 & & 6.76 & 4.83 & 1.56 & 0.73 & 0.09 & 7.21 & 107 \\
\hline $\mathrm{NO}_{3}$ & 68.0 & 50.76 & 118.80 & 18.83 & 46.13 & 6.52 & 42.07 & 113.55 & 96 \\
\hline $\mathrm{PO}_{4}$ & 4.72 & & 4.72 & 0.23 & 0.58 & 0.46 & 3.36 & 4.62 & 98 \\
\hline $\mathrm{SO}_{4}$ & 4.17 & & 4.17 & 0.03 & 0.09 & 0.54 & 3.37 & 4.03 & 97 \\
\hline Oxalate & 9.84 & & 9.84 & 0.02 & 0.04 & 1.20 & 7.18 & 8.44 & 86 \\
\hline TIC & 2.46 & 1.19 & 3.65 & 0.18 & 0.51 & 0.26 & 1.97 & 2.91 & 80 \\
\hline TOC & 2.73 & & 2.73 & 0.11 & 0.05 & 0.34 & 2.03 & 2.52 & 92 \\
\hline OII & 3.52 & 6.51 & 10.03 & 2.14 & 5.77 & 0.38 & 0.05 & 8.34 & 83 \\
\hline $\mathrm{Tc}$ & 1,244 & & 1,244 & 725 & 249 & 114 & 11.8 & 1,099 & 88 \\
\hline${ }^{73} \mathrm{Cs}_{\mathrm{s}}$ & 19,461 & & 19,461 & 11,584 & 4,004 & 1,867 & 157 & 17,613 & 91 \\
\hline${ }^{90} \mathrm{Sr}$ & 16.56 & & 16.56 & 0.53 & 0.63 & 0.62 & 2.38 & 4.17 & 25 \\
\hline${ }^{729} \mathrm{I}$ & 0.014 & & 0.014 & 0.0106 & 0.0038 & 0.0014 & $<$ det & 0.016 & 111 \\
\hline
\end{tabular}

"Wash liquid values are based on known weights of chemicals used to prepare the wash liquid, not on sample analysis. 


\section{PERFORMANCE CRITERIA}

Process performance criteria were established in the Statement of Work for sodium recovery, cesium separation, and sulfate separation. Test performance measurements exceeded all three criteria in all three test runs, as shown in Table 1-1. This section explains how the performance measurements were calculated.

\subsection{SODIUM RECOVERY}

The separation criterion for sodium recovery is that at least $50 \%$ of the input (feed) Na must be diverted to supplemental treatment. While the criterion seens straightforward, it is somewhat difficult to relate laboratory-scalc batch process data to a continuous plant operation. The "convention" established by prior Georgia Tech studies with simulants is to consider the $\mathrm{Na}$ in the washed crystals and in the accumulation as "recovered" $\mathrm{Na}$, based on the assumption that the $\mathrm{Na}$ in the accumulation would wind up in the product in an actual plant operation. That convention is followed in this report.

Thus, the percent sodium recovered can be calculated from the data in Tables 4-5 through 4-7 by adding the $\mathrm{Na}$ in the washed solids and accumulation streams, multiplying by 100 , and dividing by the $\mathrm{Na}$ in the feed stream. For Run 46 Stage 1, this process is straightforward:

$$
\% \mathrm{Na} \text { Recovered }(\text { Run } 46 \text { Stage } 1)=100 *(35.0+5.9) / 57.2=71.5 \%
$$

Only one stage was performed for Run 46 , so the calculation yields the overall sodium recovery for the SST Late flowsheet test. Run 44 was performed in two stages, so the overall sodium recovery for the SST Early flowsheet test is the sum of the two stages. The first-stage recovery is calculated in the same way as above:

$$
\% \text { Na Recovered (Run 44 Stage 1) }=100 *(64.6+17.5) / 145.3=56.5 \%
$$

The second-stage recovery is referenced to the Stage 1 feed, and an adjustment is made to account for the material removed from the Stage 2 feed for sample analysis. Note that the Stage 1 filtrate contained $62.4 \mathrm{~g} \mathrm{Na}$ (Table 4-4) while the Stage 2 feed contained $56.8 \mathrm{~g} \mathrm{Na}$ (Table 4-5), the difference being the Na removed in the analytical sample. Therefore

$$
\% \text { Na Recovered }(\text { Run } 44 \text { Stage } 2)=100 *(21.9+2.9) *(62.4 / 56.8) / 145.3=18.7 \%
$$

The combined sodium recovery for Run 44 is therefore $56.5 \%+18.7 \%=75.2 \%$.

\subsection{CESIUM DECONTAMINATION}

The separation criterion for cesium recovery, which is based on the technical requirements for RPP-17403, Demonstration Bulk Vitrification System Specification, is that the stream fed to supplemental treatment (the dissolved washed crystals) must contain less than $1.23 \times 10^{-3} \mathrm{Ci}$ of ${ }^{137} \mathrm{Cs}$ per mole of sodium. 
Tables 4-1 through 4-3 show Na concentrations in wt\% and ${ }^{137} \mathrm{Cs}$ activities in $\mu \mathrm{Ci} / \mathrm{g}$. These data can be converted into ${ }^{137} \mathrm{Cs} \mathrm{Ci} / \mathrm{mol} \mathrm{Na}^{+}$by the following unit-factor-conversion calculations. In each case, the resulting ${ }^{137} \mathrm{Cs}$ activity is well below the criterion.

For Run 44 Stage 1:

$$
\frac{0.76 \mu \mathrm{Ci}}{\text { g solids }} \times \frac{\mathrm{Ci}}{10^{6} \mu \mathrm{Ci}} \times \frac{100 \mathrm{~g} \text { solids }}{28.51 \mathrm{~g} \mathrm{Na}} \times \frac{23 \mathrm{~g} \mathrm{Na}}{\mathrm{mol} \mathrm{Na}}=6.2 \times 10^{-5} \mathrm{Ci} / \mathrm{mol} \mathrm{Na}^{+}
$$

For Run 44 Stage 2:

$$
\frac{0.62 \mu \mathrm{Ci}}{\text { g solids }} \times \frac{1 \mathrm{Ci}}{10^{6} \mu \mathrm{Ci}} \times \frac{100 \mathrm{~g} \text { solids }}{25.73 \mathrm{~g} \mathrm{Na}} \times \frac{23 \mathrm{~g} \mathrm{Na}}{\mathrm{mol} \mathrm{Na}}=5.5 \times 10^{-5} \mathrm{Ci} / \mathrm{mol} \mathrm{Na}^{+}
$$

For Run 46 Stage 1:

$$
\frac{1.19 \mu \mathrm{Ci}}{\text { g solids }} \times \frac{1 \mathrm{Ci}}{10^{6} \mu \mathrm{Ci}} \times \frac{100 \mathrm{~g} \text { solids }}{26.51 \mathrm{~g} \mathrm{Na}} \times \frac{23 \mathrm{~g} \mathrm{Na}}{\mathrm{mol} \mathrm{Na}}=1.0 \times 10^{-4} \mathrm{Ci} / \mathrm{mol} \mathrm{Na}^{+}
$$

\subsubsection{Decontamination Factors}

Another method of defining cesium separation efficiency, not included in the performance criteria, is by the decontamination factor (DF), which is defined as the $\mathrm{Cs} / \mathrm{Na}$ ratio in the fecd divided by the $\mathrm{Cs} / \mathrm{Na}$ ratio in the product. Any concentration units may be used, as long as they are the same for the feed as for the product. From Tables 4-1 through 4-3, the DF values for the three runs are as follows:

$$
\begin{aligned}
& \text { Run } 44 \text { Stage 1: } \mathrm{DF}_{\mathrm{Cs}}=(45.4 / 10.99) /(0.76 / 28.51)=154 \\
& \text { Run 44 Stage 2: } \mathrm{DF}_{\mathrm{Cs}}=(45.4 / 10.99) /(0.62 / 25.73)=173 \\
& \text { Run 46 Stage 1: } \mathrm{DF}_{\mathrm{Cs}}=(8.87 / 2.61) /(1.19 / 26.51)=76
\end{aligned}
$$

(Notice that for Run 44 Stage 2, the Cs/Na ratio for the feed refers to the Stage 1 feed.)

Decontamination factors may be calculated for any element or isotope. All analytes that remain in the liquid phase should have DFs approximately the same as those for ${ }^{137} \mathrm{Cs}$. Those include $\mathrm{Al}, \mathrm{Cr}, \mathrm{K}, \mathrm{Cl}, \mathrm{NO}_{2},{ }^{99} \mathrm{Tc}$, and ${ }^{129} \mathrm{I}$. The fact that they remain in the liquid phase and are washed out of the solids means that they often fall below or barely above detection limits in the washed solids, making the DF calculation meaningless in those cases. DF values may also be calculated for analytes that precipitate. Those are expected to be much lower, often less than 1.0. The DF values are shown in Table 5-1 for all analytes for which a meaningful DF can be measured. 
Table 5-1. Decontamination Factors.

\begin{tabular}{|l|c|c|c|}
\hline & Run 44 Stage 1 & Run 44 Stage 2 & Run 46 Stage 1 \\
\hline${ }^{137} \mathrm{Cs}$ & 154 & 173 & 76 \\
\hline $\mathrm{Al}$ & 209 & 163 & 63 \\
\hline${ }^{96} \mathrm{Tc}$ & 204 & 162 & 65 \\
\hline${ }^{90} \mathrm{Sr}$ & 1.5 & 129 & 4 \\
\hline $\mathrm{F}$ & 0.3 & 1.0 & 0.8 \\
\hline $\mathrm{PO}_{4}$ & - & 1.8 & 0.9 \\
\hline $\mathrm{SO}_{4}$ & 0.8 & - & 0.8 \\
\hline $\mathrm{TIC}$ & 1.0 & 2.8 & 0.8 \\
\hline $\mathrm{C}_{2} \mathrm{O}_{4}$ & 0.7 & - & 0.8 \\
\hline
\end{tabular}

The only other radioisotope detected in the feed solutions and not included in Table 5-1 was ${ }^{129} \mathrm{~L}$. Because it was below detection limits in the washed solids suggests that it follows ${ }^{137} \mathrm{Cs}$ through the process, which can be confirmed by comparing $\mathrm{Cs} / \mathrm{I}$ ratios in the feed and filtrate samples. In Run 44, that ratio is $1.1 \times 10^{6}$ in the feed, $1.0 \times 10^{6}$ in the Stage 1 filtrate, and $1.1 \times 10^{6}$ in the Stage 2 filtrate-virtually unchanged in all of the samples. In Run 46 , the ratio is $1.4 \times 10^{6}$ in the feed and $1.1 \times 10^{6}$ in the filtrate-a small change, probably attributable to the large uncertainty in the ${ }^{129} I$ values, which were barely above detection limits in Run 46.

Table 5-1 shows that ${ }^{90} \mathrm{Sr}$ behaves more like a solid-phase component than a liquid-phase component, especially in Stage 1 of both runs. Based on the computer flowsheet models, the solubility of phases such as $\mathrm{SrCO}_{3}$ and $\mathrm{SrSO}_{4}$ should not be exceeded in any of the tests. However, coprecipitation is likely to occur for two reasons. First, the $\mathrm{Sr}^{2+}$ ionic radius is much closer to the $\mathrm{Na}^{+}$ionic radius than is the $\mathrm{Cs}^{+}$radius, so $\mathrm{Na}^{+}$ion substitution is much more likely for $\mathrm{Sr}^{2+}$ than $\mathrm{Cs}^{+}$. (Compare ionic radii in angstroms: $\mathrm{Na}^{+}=0.95, \mathrm{Sr}^{2+}=1.13, \mathrm{Cs}^{+}=1.69$ ). Second, the anions that form low-solubility $\mathrm{Sr}^{2+}$ salts $\left(\mathrm{CO}_{3}{ }^{2-}, \mathrm{SO}_{4}{ }^{2-}, \mathrm{PO}_{4}{ }^{3}\right)$ are present in the solid phase; there are no corresponding low-solubility $\mathrm{Cs}^{+}$salts. The ${ }^{90} \mathrm{Sr} \mathrm{DF}$ may be much higher in Run 44 Stage 2 than in the other tests because of the low carbonate-sulfate-phosphate content of the solids in Stage 2.

\subsubsection{Variations in Decontamination Factor}

Several factors enter into the theoretical explanation of the variation in observed DFs from one run to another. Pertinent data for ${ }^{137}$ Cs DFs are included in Table 5-2. 
Table 5-2. Factors Responsible for DF Variations.

\begin{tabular}{|c|l|c|c|c|}
\hline Factor & \multicolumn{1}{|c|}{ Measurement } & $\begin{array}{c}\text { Run 44 } \\
\text { Stage 1 }\end{array}$ & $\begin{array}{c}\text { Run 44 } \\
\text { Stage 2 }\end{array}$ & Run 46 \\
\hline- & Cs-DF & 154 & 173 & 76 \\
\hline 1 & Cs activity in filtrate, $\mu \mathrm{Ci}^{\prime} / g$ & 139 & 232 & 139 \\
\hline 2 & Grams cake/100 g Slurry & 42.7 & 48.8 & 59.7 \\
\hline 3 & Wash liquid/filter cake & 1.31 & 1.98 & 1.61 \\
\hline $4 \mathrm{a}$ & \%ISL in cake (assumed) & 14.3 & 17.45 & 20.2 \\
\hline $4 \mathrm{~b}$ & ISL DF & 2.83 & 3.27 & 2.59 \\
\hline $4 \mathrm{c}$ & Cs activity in product, $\mu \mathrm{Ci} / \mathrm{g}$ & 0.76 & 0.62 & 1.19 \\
\hline $4 \mathrm{~d}$ & Filtrate/product activity ratio & 183 & 374 & 117 \\
\hline $4 \mathrm{e}$ & (DF) $^{\text {s }}$ & 182 & 374 & 117 \\
\hline 5 & Wt\% cake/\%ISL in cake & 299 & 280 & 295 \\
\hline
\end{tabular}

Factor $1-{ }^{137} \mathrm{Cs}$ Activity in the Filtrate: If all other factors were equal, the DF would be inversely proportional to the activity in the filtrate, i.e., a run with twice the activity in the filtrate would have half the DF. Comparing Rows 1 and 2 in Table 5-2, it is clear that this factor does not begin to tell the whole story, and it is difficult to see a correlation. Of course, all other factors are not equal.

Factor 2-W $\%$ Solids in Slurry: There was no direct measurement of the wt\% solids in the slurry, but the wt\% filter cake relative to the slurry provides an indirect measurement, and these numbers are shown in Table 5-2. It makes intuitive sense that the thicker the slurry, the more difficult it is to filter and wash the slurry, leading to higher DF.

Factor 3-Wash Liquid/Filter Cake Ratio: If all other factors were equal, the DF would be proportional to this ratio, but not directly proportional, i.e., a run with a ratio of 3.0 would have a higher DF than a run with a 1.5 ratio, but not twice as high-it would be more than twice as high, because it is the Wash Liquid:ISL ratio that actually determines the separation.

Factor 4-Wt\% ISL: All other factors being equal, there would be an inverse correlation between the wt\% ISL in the filter cake and the DF, i.e., a cake containing $30 \%$ ISL would have half the DF of a cake containing $15 \%$ ISL. There was no direct measure of the \%ISL in the filter cake, but one can be calculated from the observed ${ }^{137} \mathrm{Cs}$ activitics and wash/cake ratios. Row 4a in Table 5-2 shows a calculated value for \%ISL based on interpolation. Row $4 \mathrm{~b}$ shows the ISL dilution factor, which is equal to $\left(0.2^{*}\right.$ wash/cake $+\%$ ISL)/\%ISL, assuming perfect mixing of one-fifth of the wash liquid with the ISL. Row $4 \mathrm{c}$ is the measured activity of ${ }^{137} \mathrm{Cs}$ in the product (washed) crystals. Row $4 \mathrm{~d}$ is the ${ }^{137} \mathrm{Cs}$ activity in the filtrate divided by the ${ }^{137} \mathrm{Cs}$ activity in the washed crystals, which is a ratio analogous to the DF but does not take into account the differences in $\mathrm{Na}$ concentration. Finally, row $4 \mathrm{e}$ is the ISL dilution factor raised to the fifth power (for five washes). The interpolation is done by adjusting the \%ISL incrementally until rows $4 \mathrm{~d}$ and $4 \mathrm{e}$ are equal. This factor goes a long way in explaining the observed differences in DF between runs. It does not answer the question: What causes the variation in \%ISL? Answers include but may not be limited to particle size distribution and crystal morphology. 


\section{RPP-RPT-31352, Rev. 0}

Factor 5-Wt\% Solids/Wt\% ISL Ratio: This is not really a factor as much as an explanation for prior factors. It is noteworthy that this ratio is nearly a constant for all three runs.

\subsection{SULFATE:SODIUM MOLE RATIO}

The separation criterion for sulfate is that the $\mathrm{SO}_{4}: \mathrm{Na}$ mole ratio in the purge stream (the highactivity waste returned to the double-shell tanks for eventual feed to the Waste Treatment and Immobilization Plant) be less than 0.01 . In the case of the laboratory tests, the purge stream is represented by the final filtrate (Stage 2 filtrate in Run 44, Stage 1 filtrate in Run 46). The ratio is found by converting the wt\% values in the tables into mol/100 $\mathrm{g}$ by dividing each table value by the respective formula weight $\left(23.0 \mathrm{~g} / \mathrm{mol}\right.$ for $\mathrm{Na}, 96.0 \mathrm{~g} / \mathrm{mol}$ for $\left.\mathrm{SO}_{4}\right)$.

$$
\begin{aligned}
& \text { Run 44: } \mathrm{SO}_{4}: \mathrm{Na} \text { mole ratio }=(0.379 / 96.0) /(20.04 / 23.0)=0.0047 \\
& \text { Run 46: } \mathrm{SO}_{4}: \mathrm{Na} \text { mole ratio }=(0.033 / 96.0) /(17.56 / 23.0)=0.00045
\end{aligned}
$$

Results are shown in Table 1-1. Both runs exceeded the criterion. 


\section{RPP-RPT-31352, Rev. 0}

\section{CONCLUSIONS}

The hot cell test results conclusively show, with actual tank waste samples, that the desired separations are achievable. At least on a laboratory scale, the fractional crystallization process can provide a viable pretreatment method to convert medium-curie waste into low-curie feed for a supplemental treatment process.

Another vital conclusion that may be drawn from the hot cell tests ${ }^{\prime}$ is that the actual tank waste samples behaved the same as the simulated waste samples tested previously (RPP-RPT-27239 and RPP-RPT-30905, Fractional Crystallization Simulant Test Comparison). There were no significant differences in the physical behavior of the actual vs. simulated tank waste during evaporation, filtration, and washing opcrations. There were no significant differences in the amounts and types of product salts. Therefore, one can conclude

a. Process parameters may be tested and evaluated in the laboratory using simulated tank waste samples with some assurance that the findings will be applicable to actual tank waste.

b. Pilot-scale work may be carried out with simulated tank waste with some assurance that the findings will be applicable to actual tank waste in the actual plant operation.

\footnotetext{
' Although the feed stocks for these tests were derived from a composite of many different single-shell tanks, the conclusions drawn here still may be limited to the two feed compositions actually tested-SST Early and SST Late. Feeds with significantly different compositions than those tested (e.g., feeds with high organic complexant or high phosphate levels) may behave differently. Additional testing may be necessary to demonstrate the correlation between simulated and actual tank waste samples in such cases.
} 
RPP-RPT-31352, Rev. 0

\section{REFERENCES}

CH2M-0600248, 2006, "Preparation of Composite Tank Waste Samples for EM-21 Project," (external letter from D. L. Herting to E. A. Nelson, COGEMA, February 2), CH2M HILL Hanford Group, Inc., Richland, Washington.

RPP-17403, 2006, Demonstration Bulk Vitrification System Specification, Rev. 4, CHIM HILL Hanford Group, Inc., Richland, Washington.

RPP-RPT-26474, 2005, Fractional Crystallization of Waste from Tank 241-S-112, Rev. 0, CH2M HILL Hanford Group, Inc., Richland, Washington.

RPP-RPT-27239, 2006, Hanford Medium/Low Curic Waste Pretreatment Project-Phase I Laboratory Report, Rev. 0, CHI2M HILL Hanford Group, Inc., Richland, Washington.

RPP-RPT-30905, 2006, Fractional Crystallization Simulant Test Comparisons, Rev, 0, CH2M HILL Hanford Group, Inc., Richland, Washington [in draft]. 


\section{ACKNOWLEDGEMENTS}

"It takes a village." A large number of people contributed to the success of the hot cell test program-so many that it would be impractical to mention all of them by name. The author would like to extend special thanks, though, to the following major contributors.

- John Smith provided the skill to transform the concept into reality. He made the electrical connections to get the computer to talk to the apparatus. He made the design changes needed to make the Georgia Tech apparatus more amenable to hot cell operation. And at times he seemed more like the "slave" than the "master" when he was putting in long hours in front of the hot cell operating the master-slave manipulators.

- Carl Nick and Maggie Ulk provided many hours of laboratory support in preparation for the hot cell tests-preparing reagents and doing practice runs with simulants. Carl also assisted John with manipulator operations and monitored the progress of the hot cell tests during some "all-nighters."

- Don Geniesse (COGEMA) provided the computer modeling and is responsible for the flowsheets shown in Figures 2-1 and 2-2.

- George ("PJ") Dumont (Gcorgia Tech) traveled here from Atlanta to help set up the original apparatus and guide us through our first simulant test practice runs to help ensure that equipment and procedures were comparable between our lab and theirs.

- Bob Weis coordinated the work of dozens of people to plan and install the equipment into the hot cell.

- Steve McKinney coordinated the efforts of the analytical laboratory.

- Gary Cooke and Dr. Wade Warrant provided the SEM/EDS and XRD analyses, respectively, of the washed solids samples.

- Oversight, guidance, and helpful comments were provided throughout the project by Dennis Hamilton (CH2M HILL project manager), Eric Nelson (COGEMA project manager), and Dr. Ron Rousseau (Georgia Tech).

- Detailed reviews and helpful comments on the report were provided by Dr. Jim Person, Mike Johnson, Dennis Hamilton, Eric Nelson, Don Geniesse, and Dr. Ron Rousscau. 
RPP-RPT-31352, Rev. 0

\author{
APPENDIX
}

\title{
ANALYTICAL SAMPLE RESULTS AND DILUTION FACTORS
}

\section{List of Figures}

Figure A-1. Analytical Sample Points

\section{List of Tables}

Table A-1. Analytical Sample Dilution Factors A-2

Table A-2. Complete Analytical Results for Sample Early-UId.................................................... A-3

Table A-3. Abridged Analytical Results for Sample Early-S1d ...................................................A-6

Table A-4. Abridged Analytical Results for Sample Early-F1d................................................... A-7

Table A-5. Abridged Analytical Results for Sample Early-R1d ................................................ A-8

Table A-6. Abridged Analytical Results for Sample Early-Ald ................................................. A-9

Table A-7. Abridged Analytical Results for Sample Early-U2d ............................................. A-10

Table A-8. Abridged Analytica! Results for Sample Early-\$2d................................................. A-11

Table A-9. Abridged Analytical Results for Sample Early-F2d .............................................. A-12

Table A-10. Abridged Analytical Results for Sample Early-R2d ............................................. A-13

Table A-1 1. Abridged Analytical Results for Sample Early-A2d .............................................. A-14

Table A-12. Abridged Analytical Results for Sample Late-Uld................................................ A-15

Table A-13. Abridged Analytical Results for Sample Late-S1d ............................................... A-16

Table A-14. Abridged Analytical Results for Sample Late-F1d ............................................... A-17

Table A-15. Abridged Analytical Results for Sample Latc-R1d ................................................. A-18

Table A-16. Abridged Analytical Results for Sample Late-Ald ............................................... A-19 


\section{APPENDIX \\ ANALYTICAL SAMPLE RESULTS AND DILUTION FACTORS}

Samples for chemical and radionuclide analyses were taken at the sample points indicated in Figure A-1. The schematic shows a two-stage test (SST Early Run 44). The left half of the schematic applies to a one-stage test (SST Late Run 46).

Figure A-1. Analytical Sample Points (gray circles).

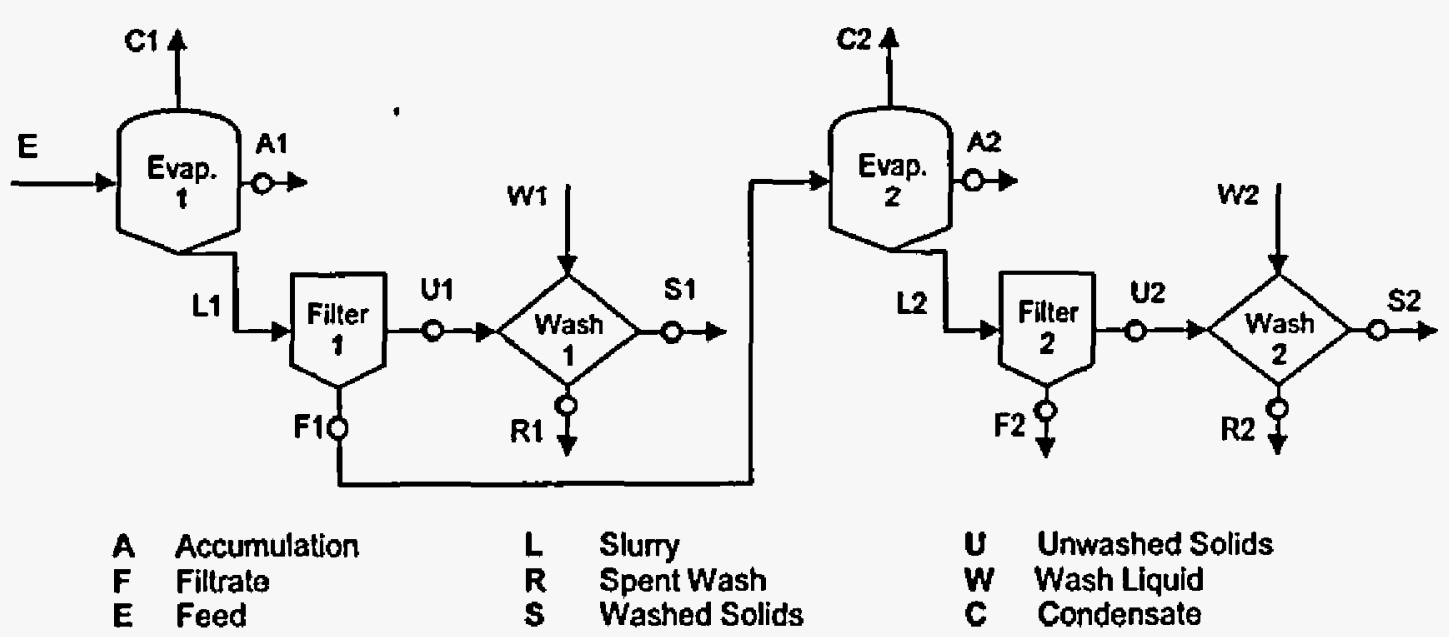

All of the samples were diluted with water prior to submission for analysis, so the subscript ' $d$ ' was added to each sample name to distinguish it from the undiluted process stream indicated in the figure. A prefix, "Early" or "Late," was added to distinguish the two runs. So, the sample names corresponding to the sample points indicated in the figure were, e.g., Early-Ald, EarlyF2d, Late-Uld, etc.

The SST Early and SST Late feed solutions (E) were analyzed at the time of make-up, and the results were issued previously (external letter CH2M-0600248, "Preparation of Composite Tank Waste Samples for EM-21 Project"). Wash liquid (W) compositions were based on chemical make-up rather than on sample analyses. Condensates (C) were not analyzed but were presumed to contain negligible amounts of all analytes.

Dilution factors for all samples are shown in Table A-1. The rows in Table A-1 are defined as follows:

a. "Sample wt" is the weight of undiluted process stream liquid or solid corresponding to the sample points in Figure A-1.

b. "Density" is the flowsheet-predicted density of the undiluted liquid process streams. 
c. " $\mathrm{H}_{2} \mathrm{O}$ added" is the weight of water added to prevent precipitation of the liquid samples or to dissolve the solid samples.

d. "Total volume" is the calculated total sample volume based on the following assumptions:

1. Volume of dissolved solids samples equals the weight of water plus one-half the weight of the undissolved solids.

2. Volume of diluted liquid samples assumes additive volumes (undiluted sample plus water).

c. "Wt\% factor" is the conversion factor from reported units $(\mu \mathrm{g} / \mathrm{mL})$ into wt $\%$ of undiluted sample for all chemical analytes.

f. "Ci factor" is the conversion factor from reported volumetric units $(\mu \mathrm{g} / \mathrm{mL}$ or $\mu \mathrm{Ci} / \mathrm{mL})$ into gravimetric units of $\mu \mathrm{g} / \mathrm{g}\left({ }^{99} \mathrm{Tc}\right)$ or $\mu \mathrm{Ci} / \mathrm{g}$ (all other isotopes).

Table A-1. Analytical Sample Dilution Factors.

\begin{tabular}{|c|c|c|c|c|c|c|}
\hline Early= & $\mathbf{E}$ & U1d & S1d & F1d & Rld & Ald \\
\hline Sample wt & & 2.02 & 4.19 & 342.08 & 327.60 & 91.35 \\
\hline Density & 1.290 & - & - & 1.430 & 1.395 & $\overline{-}$ \\
\hline $\mathrm{H}_{2} \mathrm{O}$ added & - & 32.85 & 36.82 & 197.17 & 197.08 & 526.57 \\
\hline Total volume & $\overline{-}$ & 33.86 & 38.915 & 436.39 & 431.92 & 572.25 \\
\hline $\mathrm{W}_{1} \%$ factor & $7.58 \mathrm{E}-05$ & $1.68 \mathrm{E}-03$ & $9.29 \mathrm{E}-04$ & $1.28 \mathrm{E}-04$ & $1.32 \mathrm{E}-04$ & $6.26 \mathrm{E}-04$ \\
\hline Ci factor & 0.76 & 16.76 & 9.29 & 1.28 & 1.32 & 6.26 \\
\hline Early- & $\mathbf{E}$ & U2d & S2d & F2d & R2d & A2d \\
\hline Sample wt & $\overline{-}$ & 3.92 & 4.14 & 121.77 & 243.14 & 7.88 \\
\hline Density & $=$ & $\overline{-}$ & - & 1.422 & 1.336 & 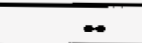 \\
\hline $\mathrm{I}_{2} \mathrm{O}$ added & - & 33.19 & 31.96 & 199.12 & 198.15 & 380.22 \\
\hline Total volume & $=$ & 35.15 & 34.03 & 284.75 & 380.14 & 384.16 \\
\hline Wt\% factor & $=$ & $8.97 \mathrm{E}-04$ & $8.22 \mathrm{E}-04$ & 2.34E-04 & $1.56 \mathrm{E}-04$ & $4.88 \mathrm{E}-03$ \\
\hline Ci factor & $=$ & 8.97 & 8.22 & 2.34 & 1.56 & 48.75 \\
\hline Late- & $\mathbf{E}$ & Uid & S1d & F1d & Rid & Ald \\
\hline Sample wt & $=$ & 1.50 & 3.14 & 83.12 & 169.47 & 20.43 \\
\hline Density & 1.060 & $=$ & $=$ & 1.447 & 1.394 & - \\
\hline II ${ }_{2} \mathrm{O}$ added & - & 33.21 & 32.13 & 202.29 & 198.76 & 220.30 \\
\hline Total volume & $=$ & 33.96 & 33.70 & 259.73 & 320.33 & 230.52 \\
\hline Wi $\%$ factor & $9.43 E-05$ & $2.26 \mathrm{E}-03$ & $1.07 \mathrm{E}-03$ & 3.12E-04 & $1.89 \mathrm{E}-04$ & $1.13 \mathrm{E}-03$ \\
\hline Ci factor & 0.94 & 22.64 & 10.73 & 3.12 & 1.89 & 11.28 \\
\hline
\end{tabular}

Complete analytical results for diluted sample Early-Uld are shown in Table A-2. Most of the analytes werc below detection limits in this and all other samples. The detection limits for this sample are typical of all the samples that were run, so those data are not repeated in subsequent tables. Tables A-3 through A-16 show an abbreviated set of analytical results for the remaining samples. Dilution-corrected analytical results are shown in the body of the report (Tables 4-1 through 4-3). 
RPP-RPT-31352, Rev. 0

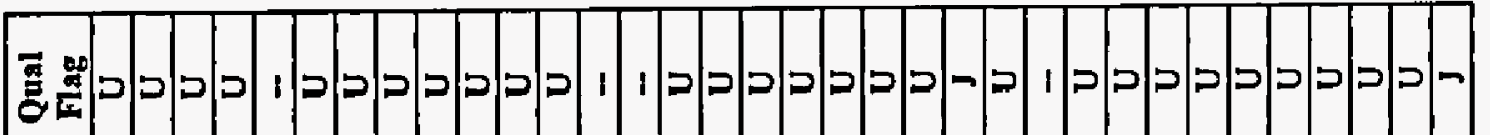

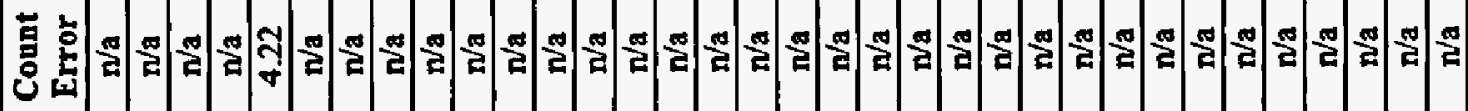

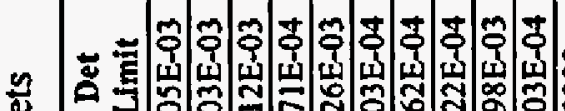

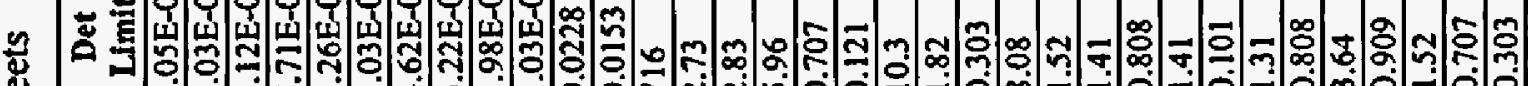

$\frac{\Phi}{n}$

$\forall$

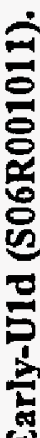

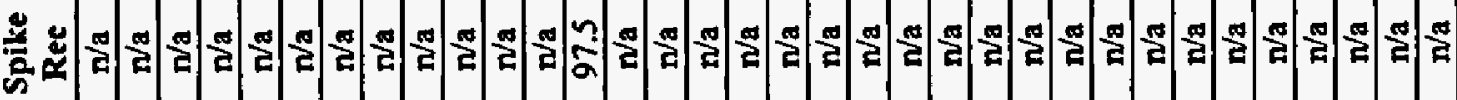
n

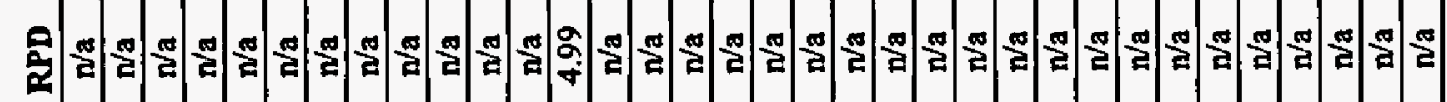

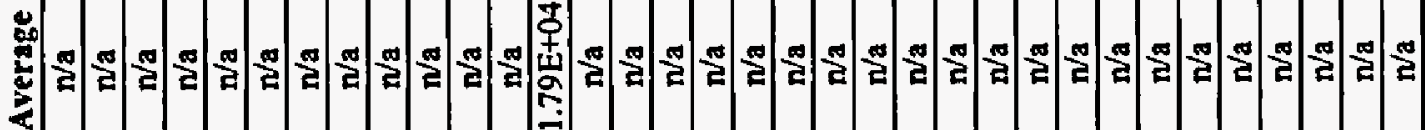

ㄹ.

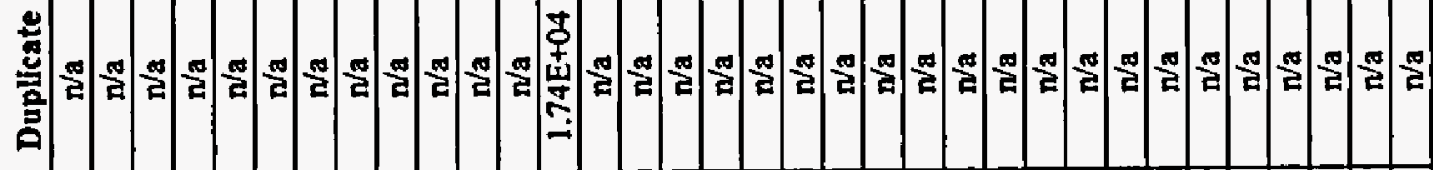

-

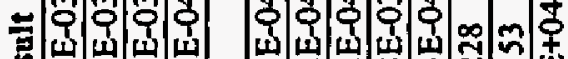

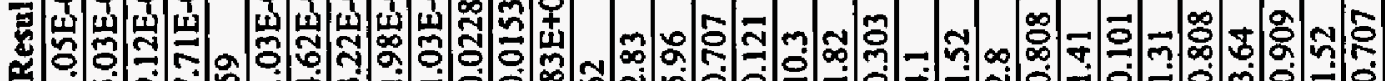

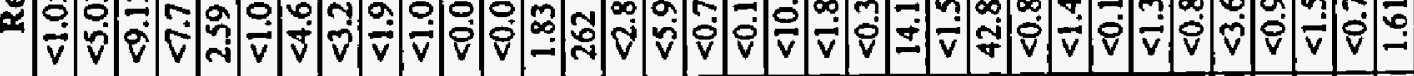

胥

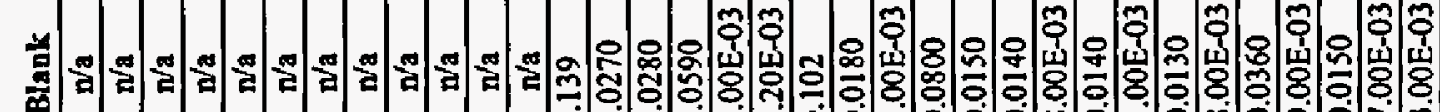
守

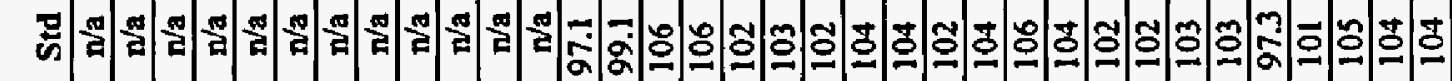

¿ 능

8

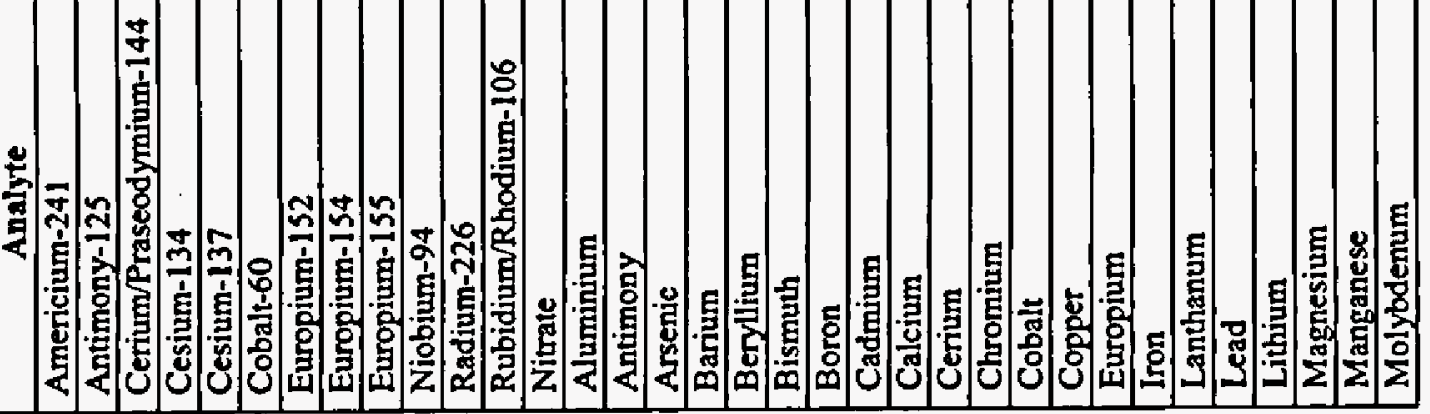


RPP-RPT-31352, Rev. 0

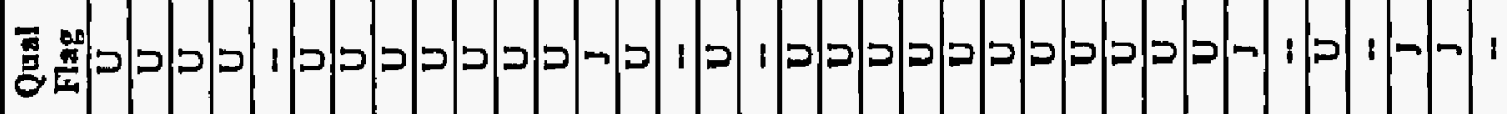

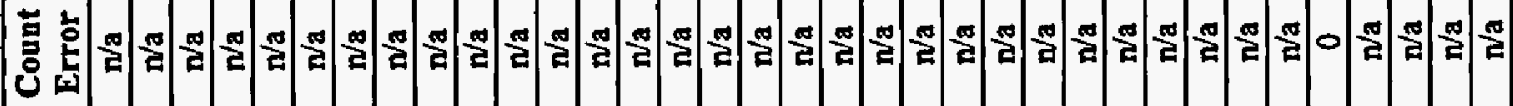

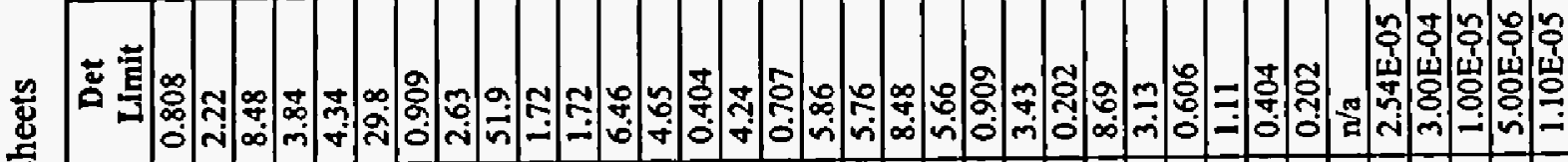

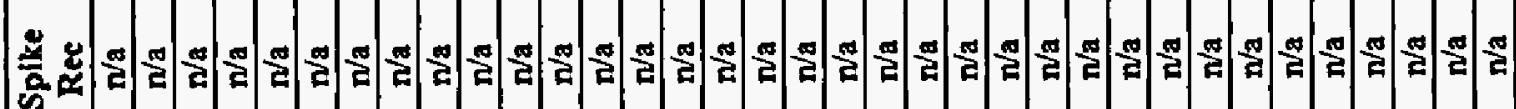

$\bar{\sigma}$

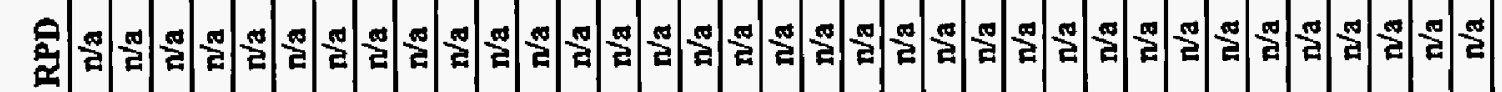

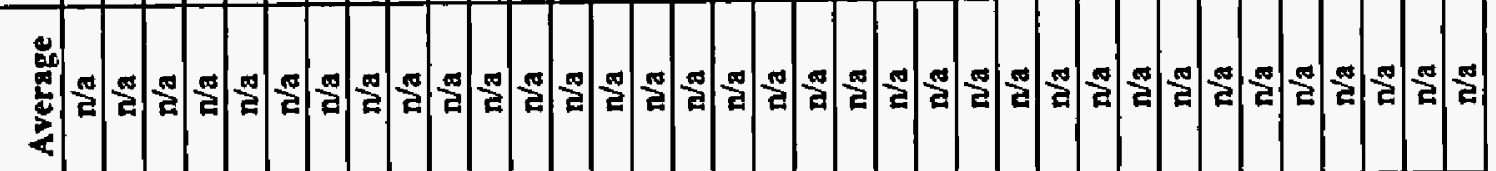

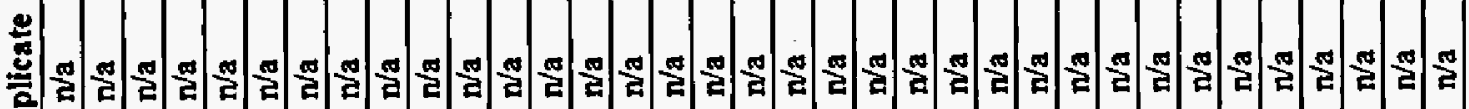 . ค

泀

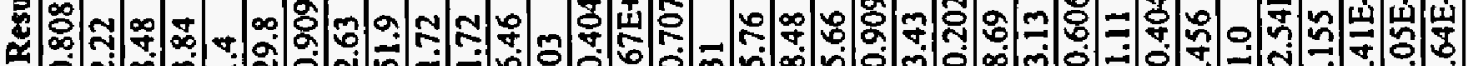

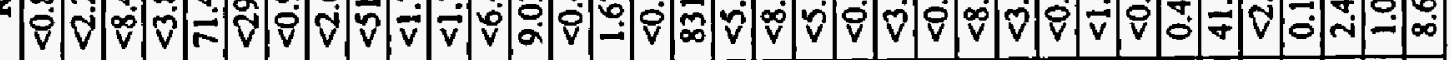

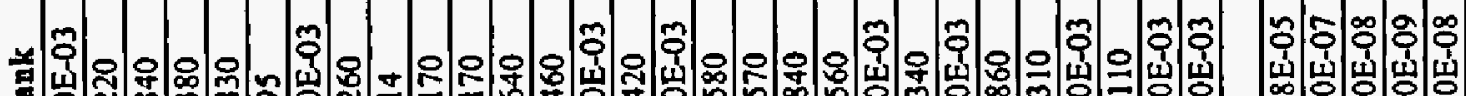
苗

Q

$\stackrel{2}{2}$

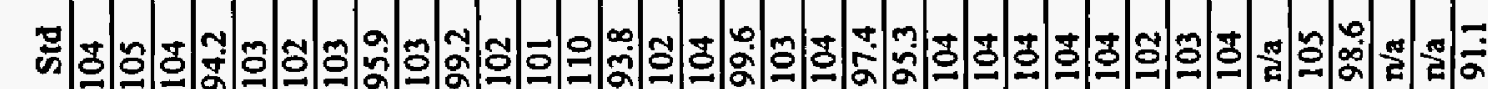
10

$\frac{1}{2}$

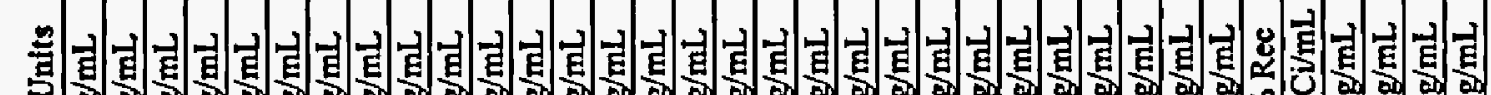

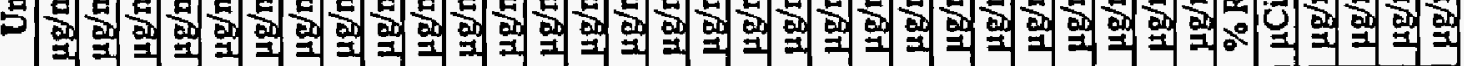

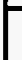

$\frac{5}{5}$

焉 
RPP-RPT-31352, Rev. 0

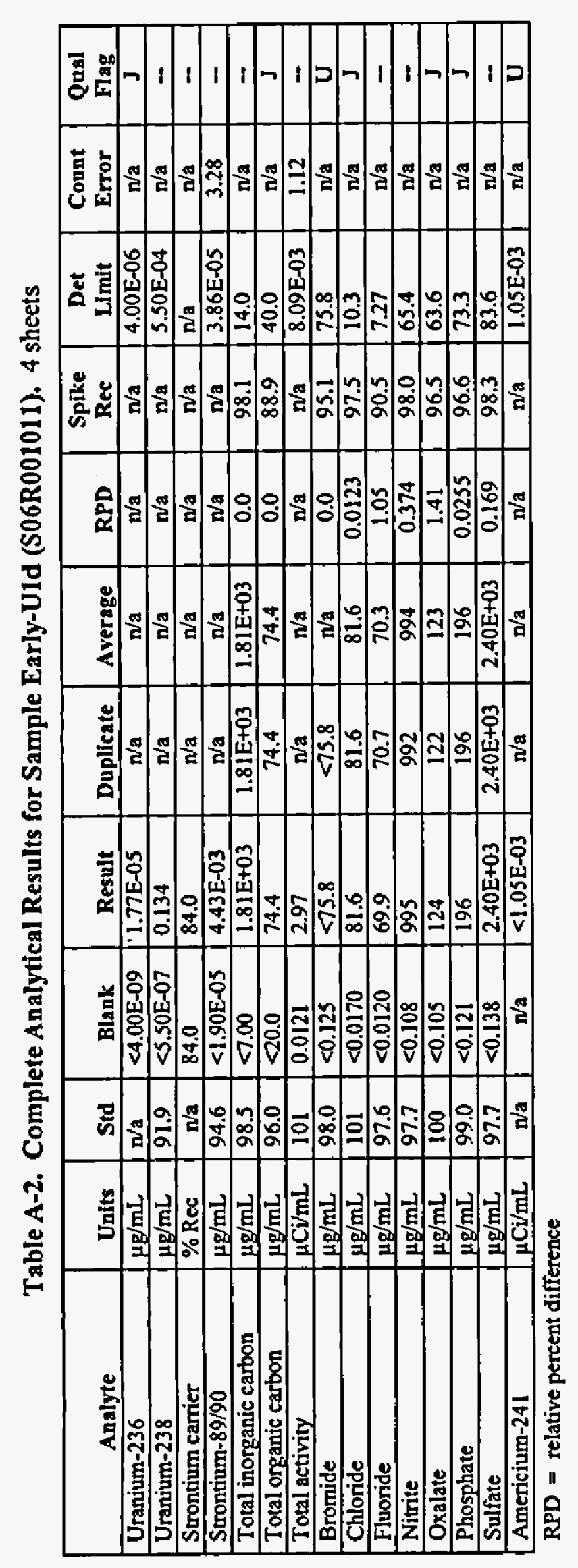

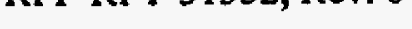




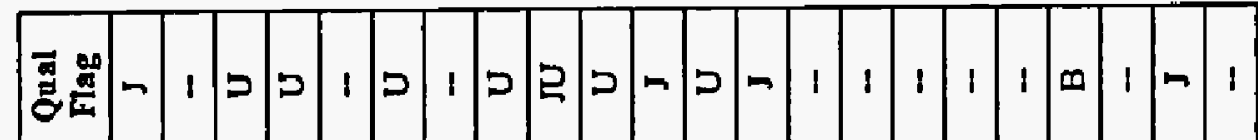

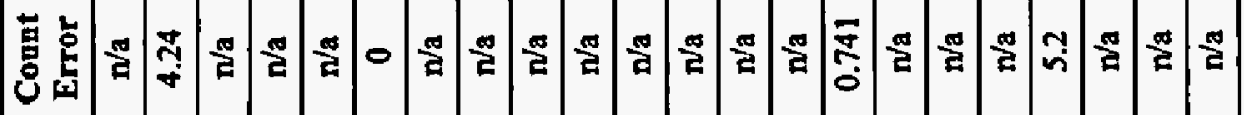

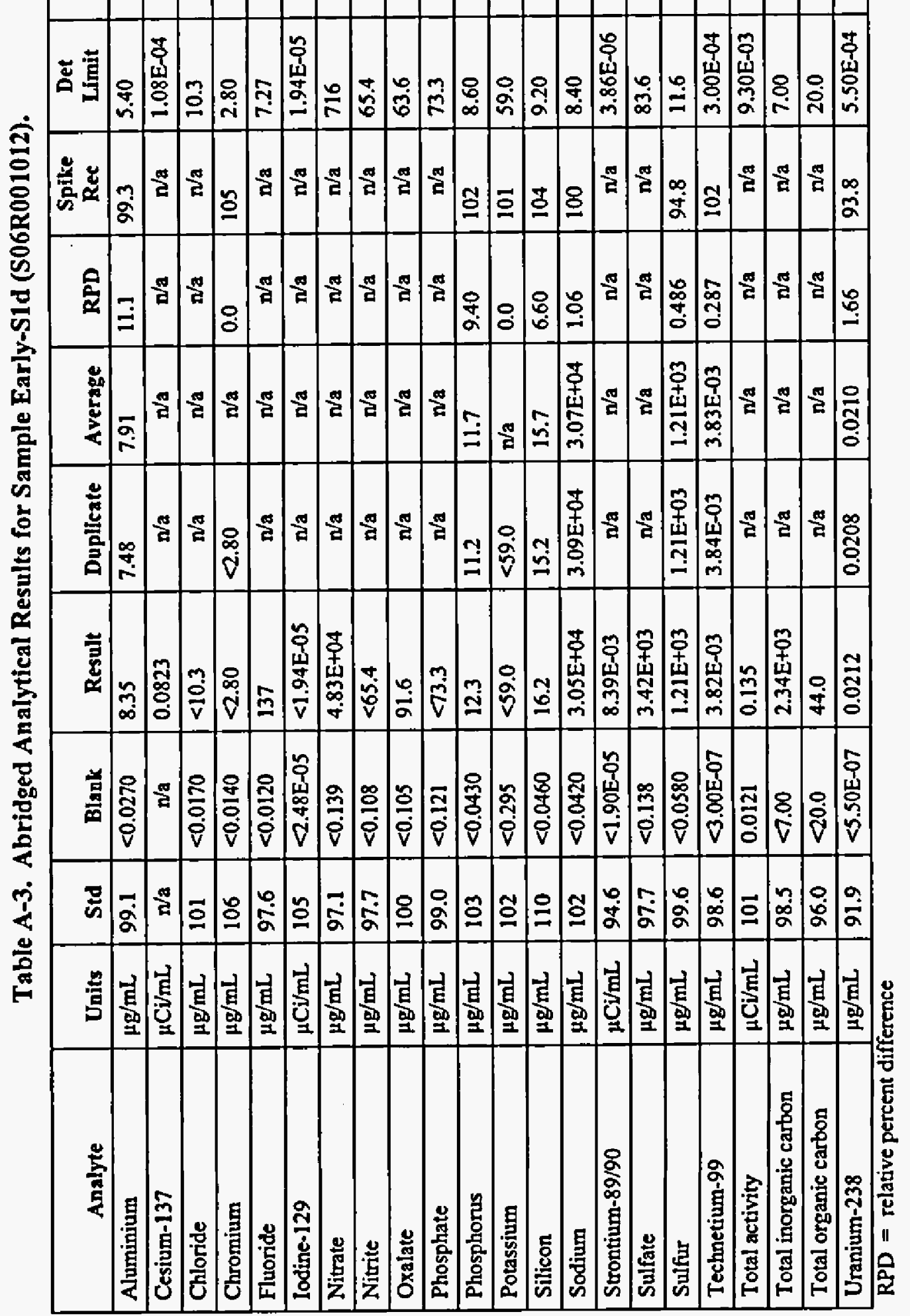


RPP-RPT-31352, Rev. 0

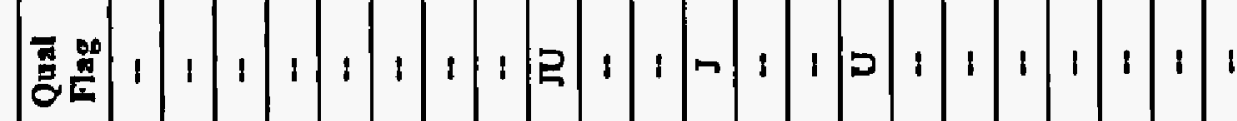

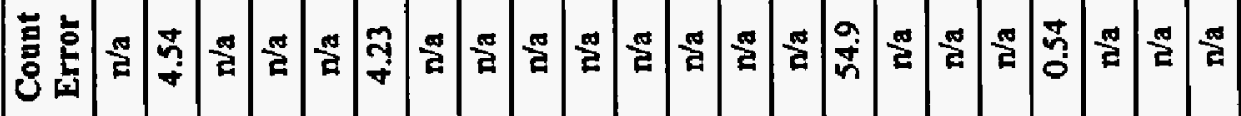

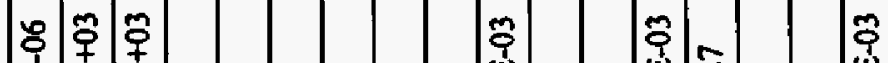

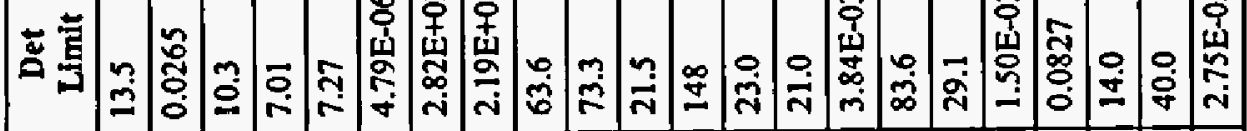

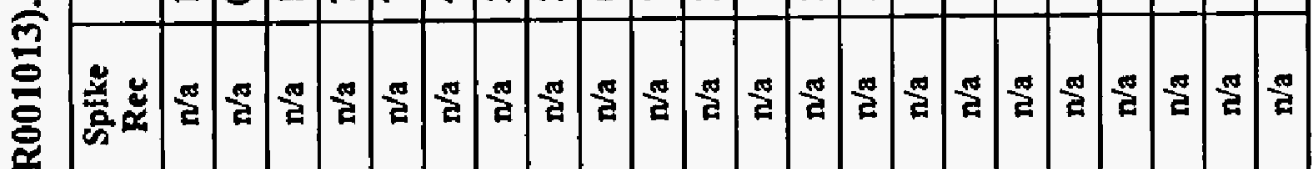

$\sum_{0}$

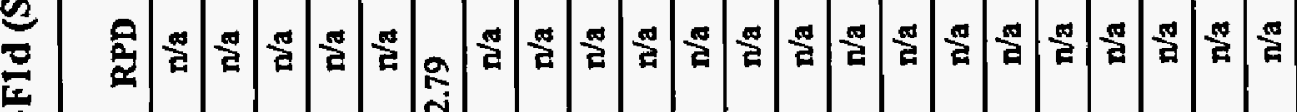

⿶

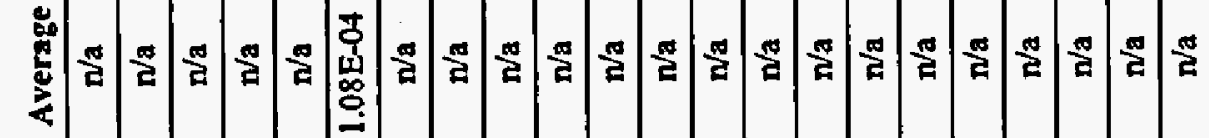

点

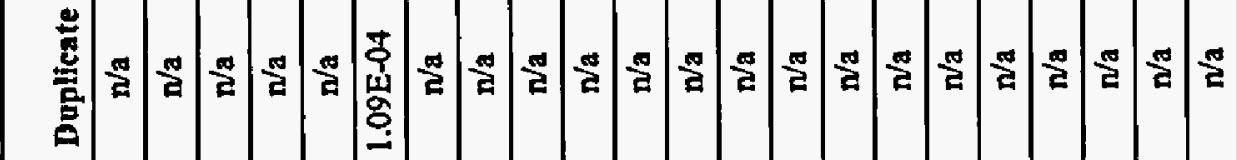

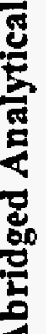

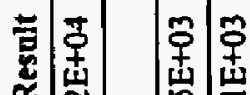

प๐

m

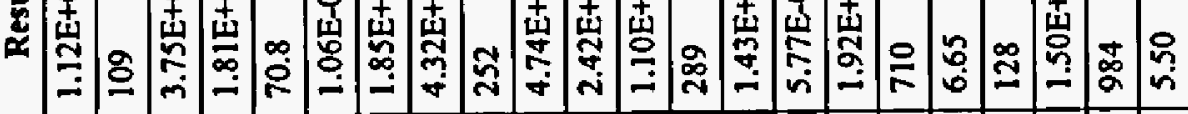

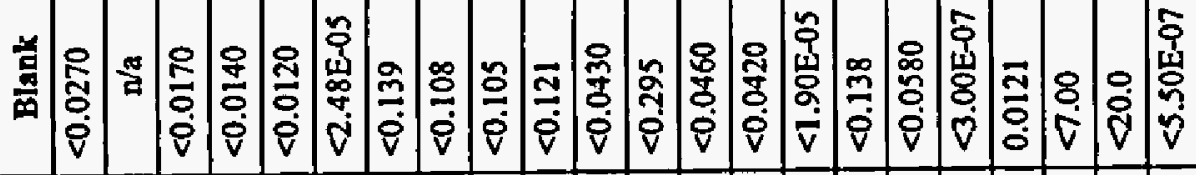

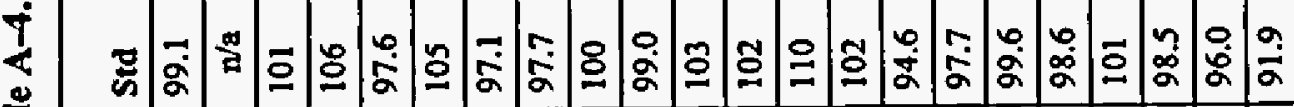

产

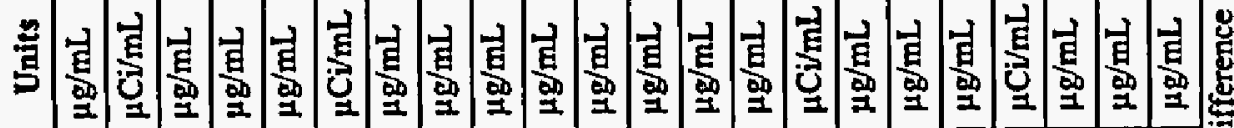

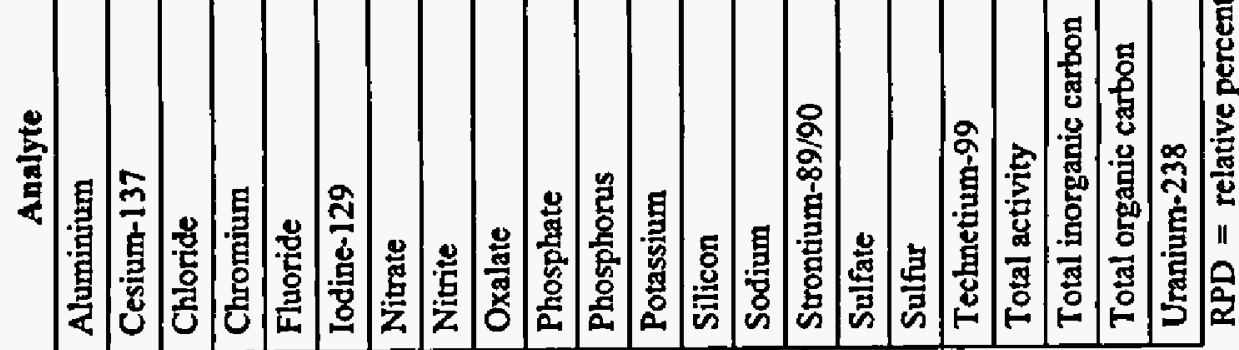


RPP-RPT-31352, Rev. 0

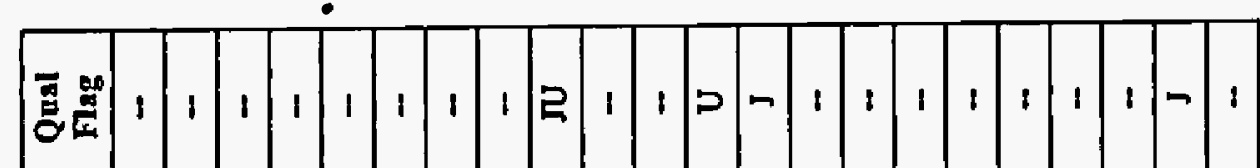

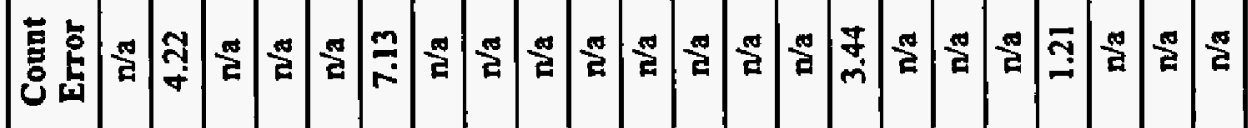

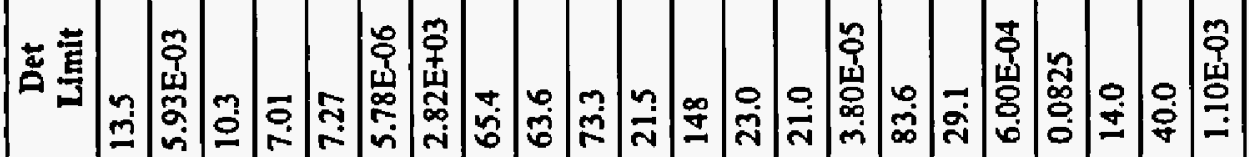

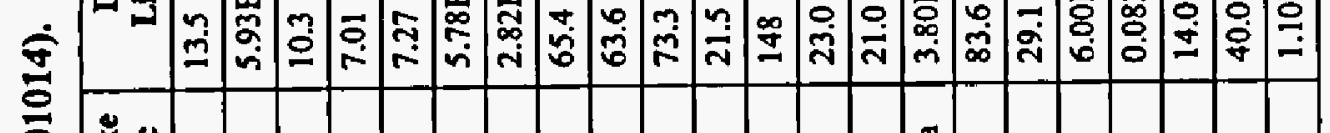

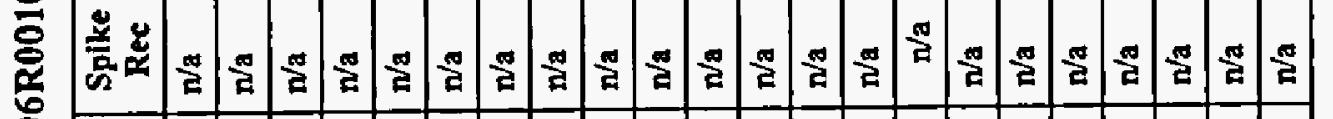

它

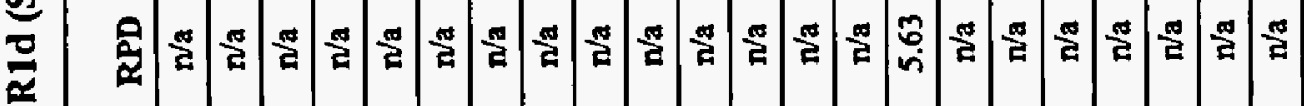

竞

4

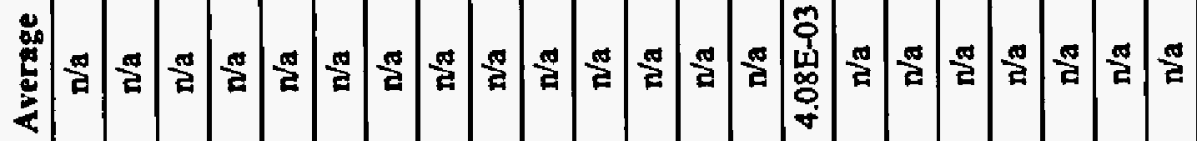

产

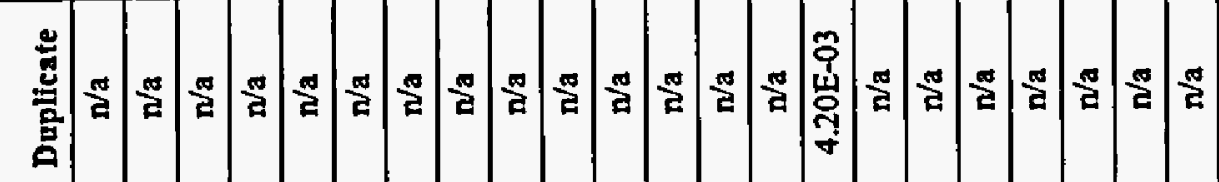

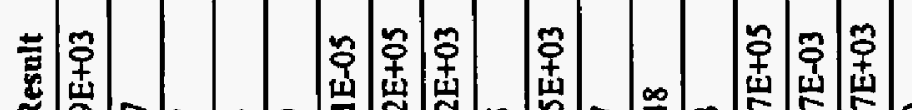

辛旁蜶

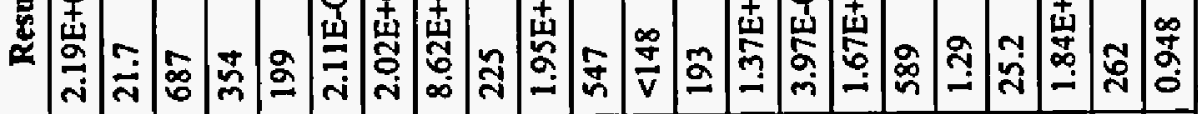

1 1 n

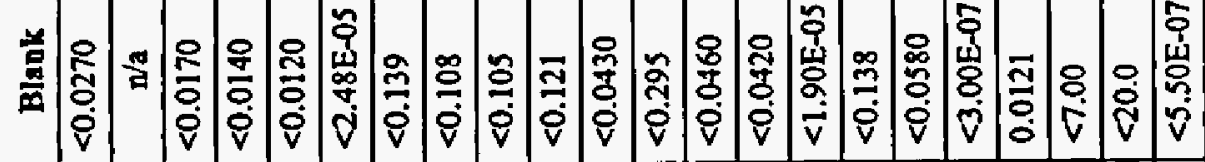

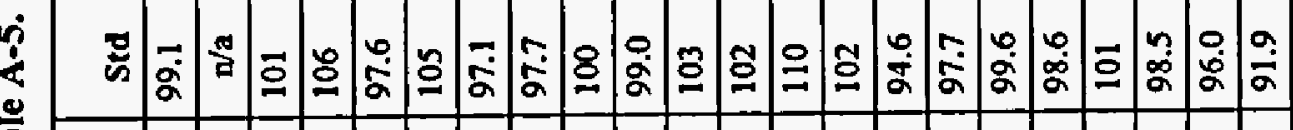

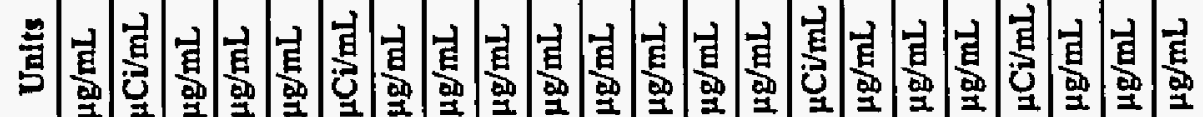

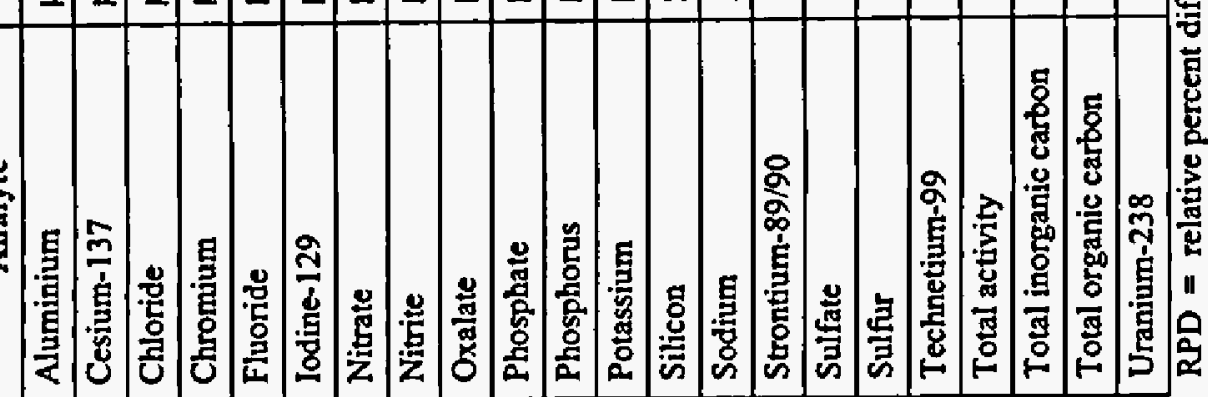


RPP-RPT-31352, Rev. 0

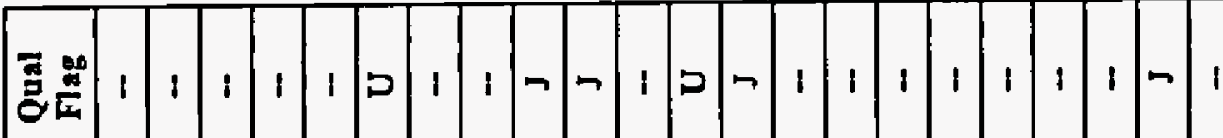

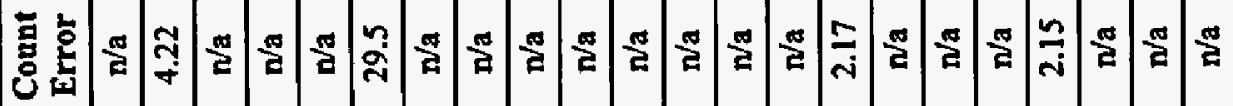

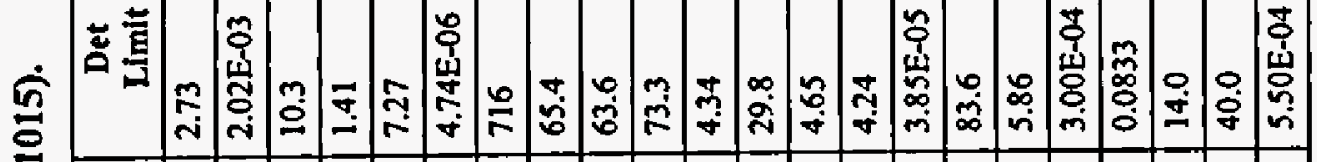

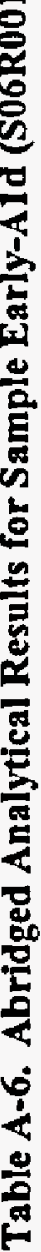

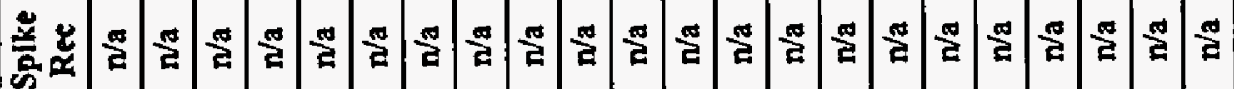

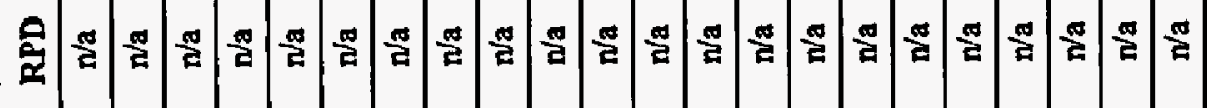

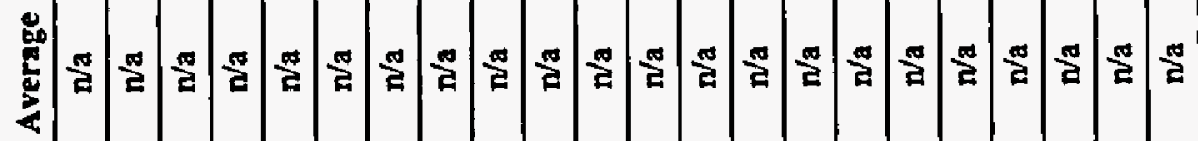

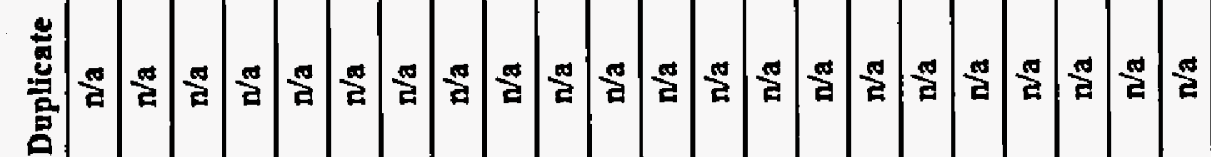

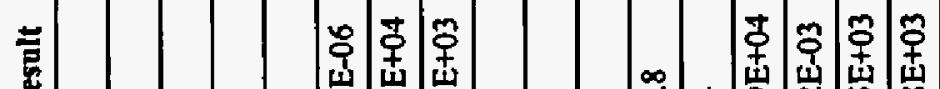

象

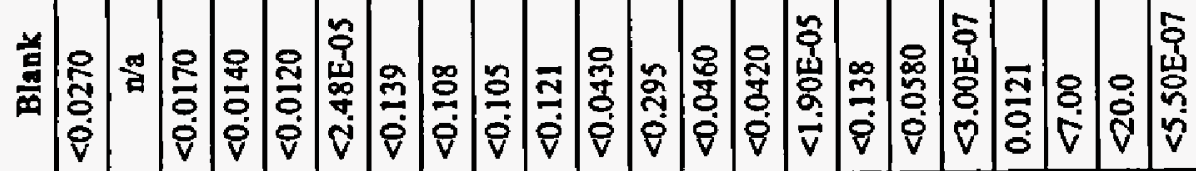

至

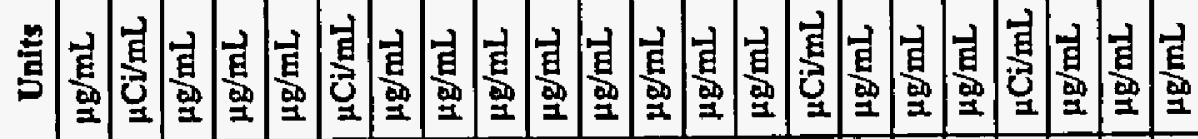

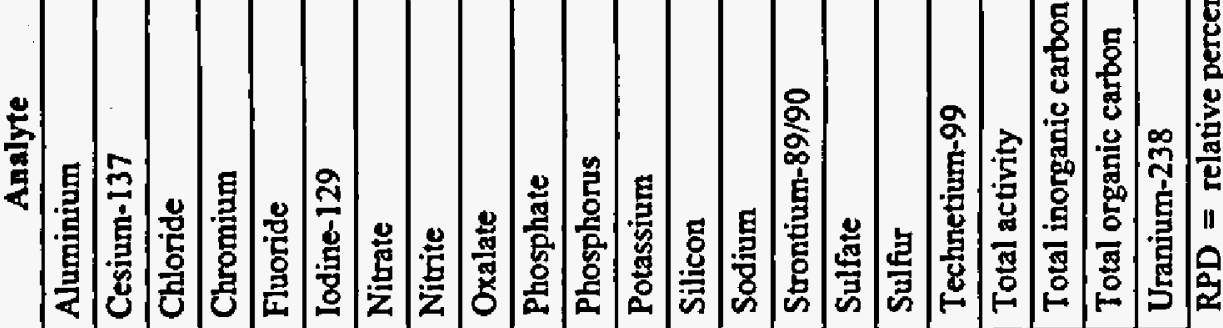


RPP-RPT-31352, Rev, 0

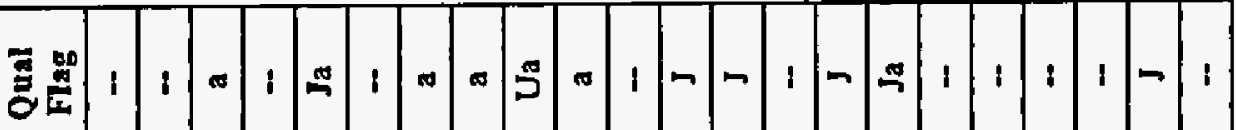

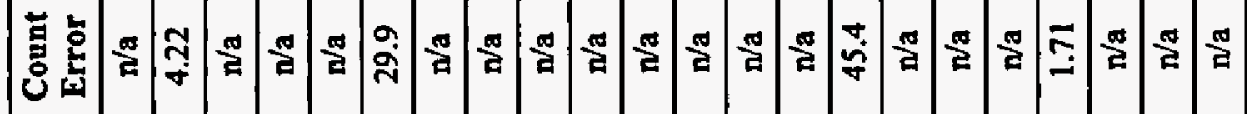

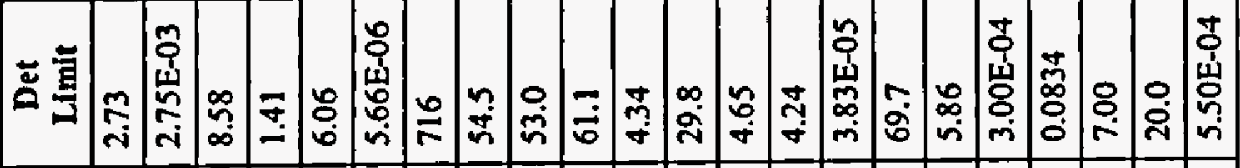

옹

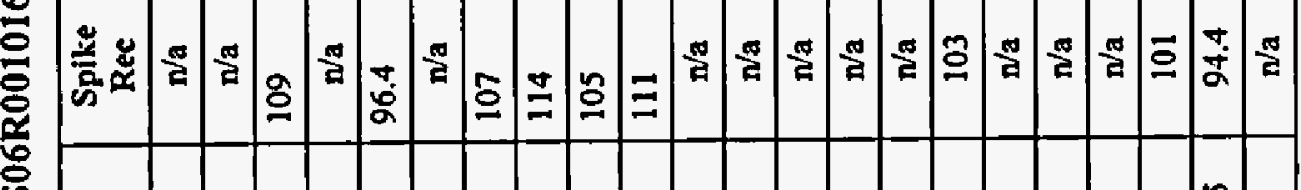

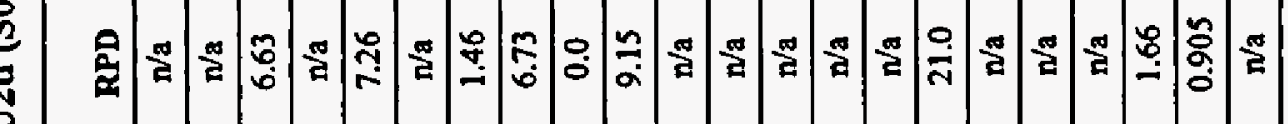

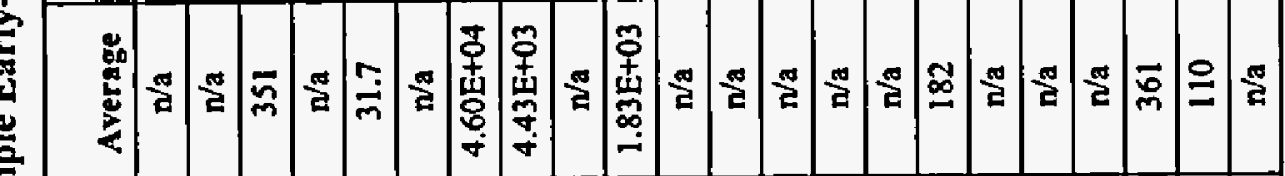

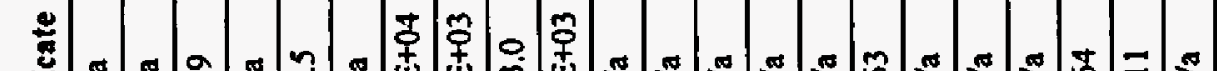

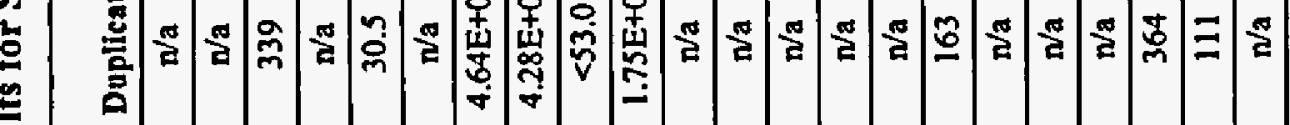

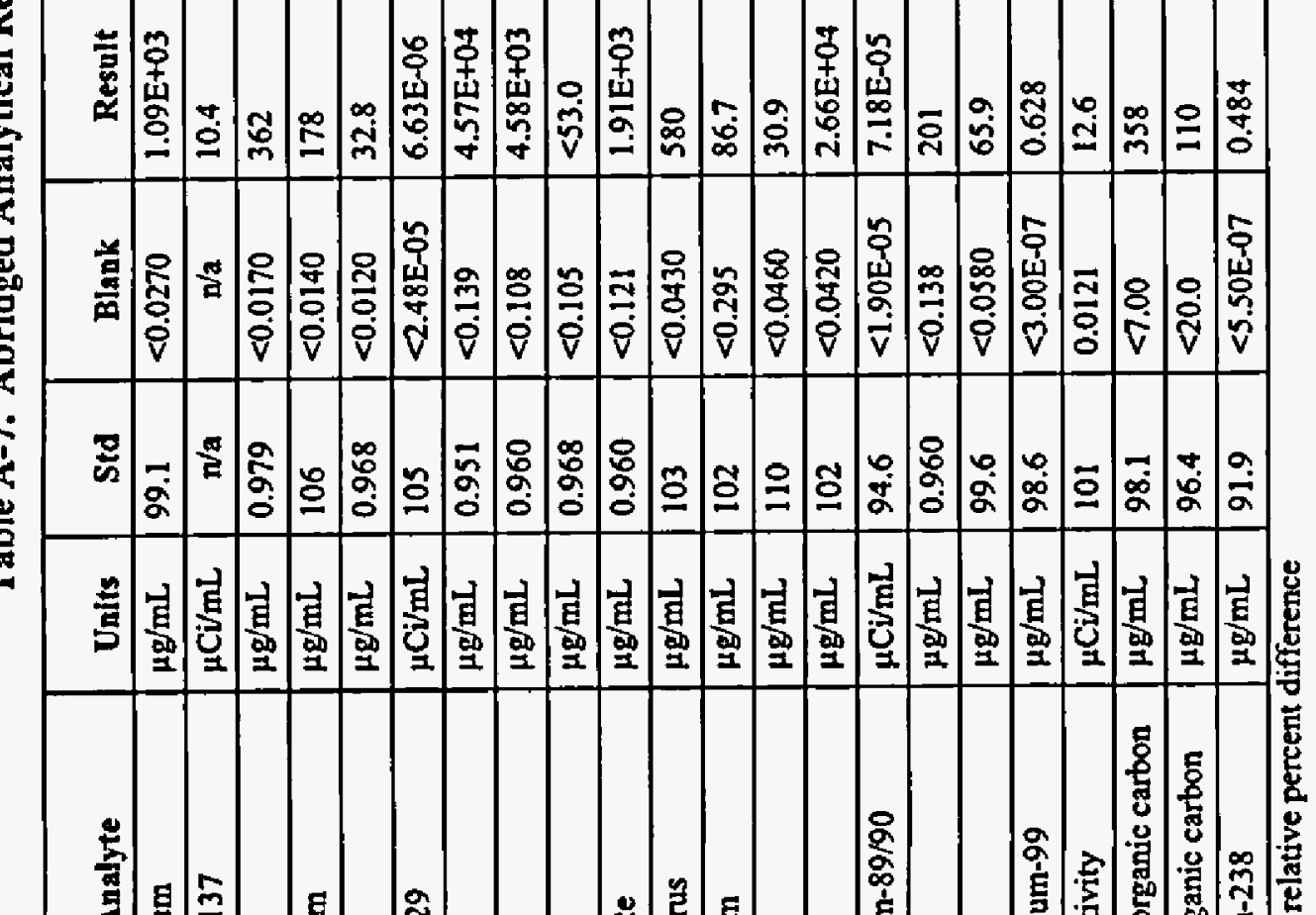

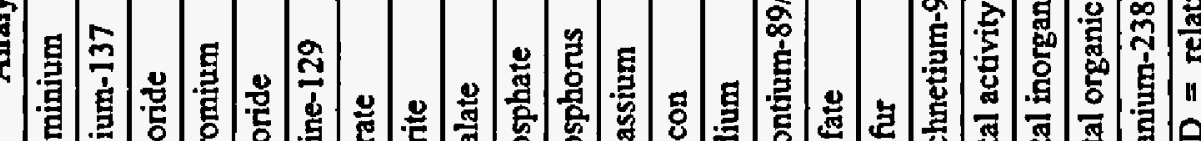

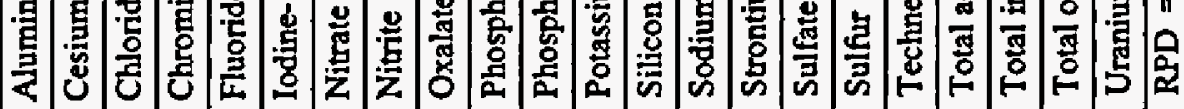


RPP-RPT-31352, Rev. 0

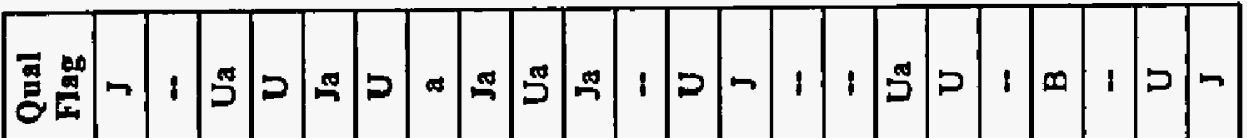

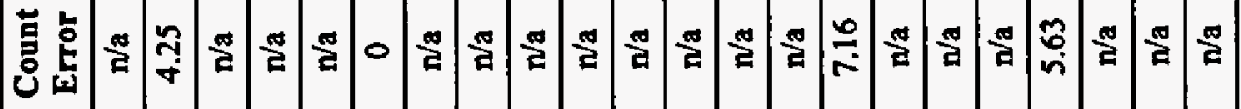

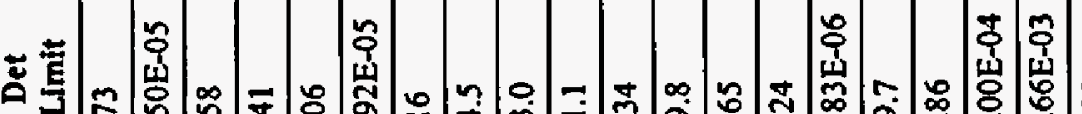

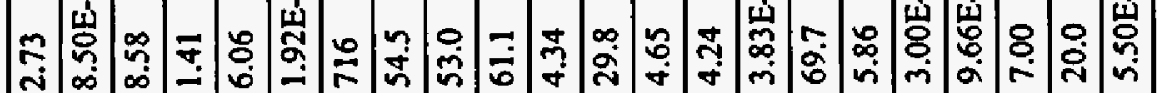

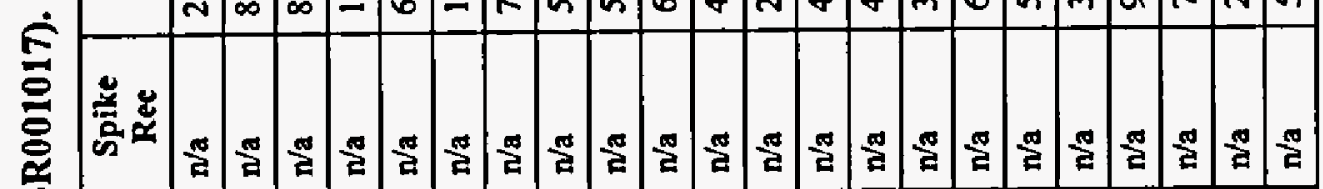

$\wp_{0}$

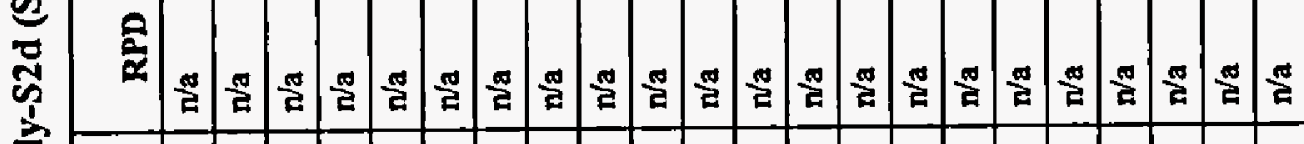

(a)

$\stackrel{2}{5}$

要

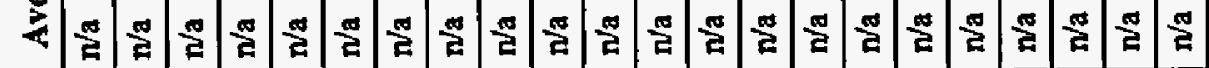

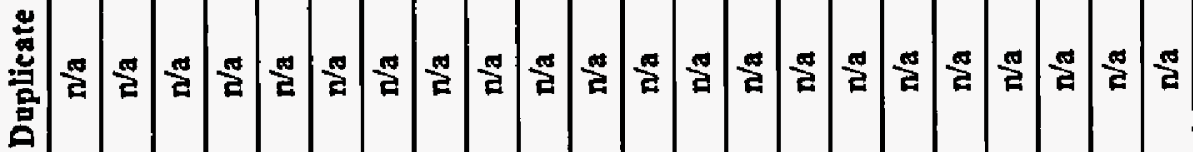

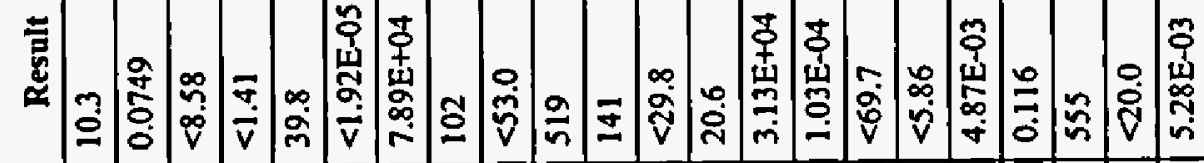

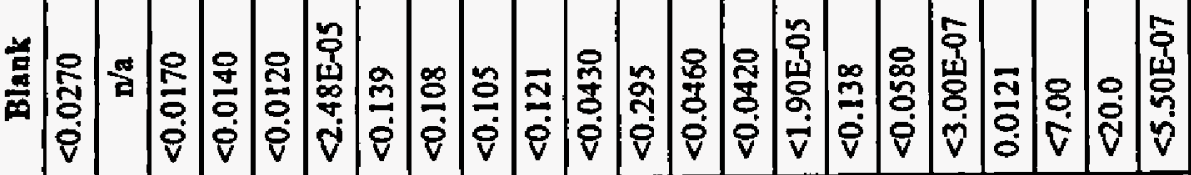

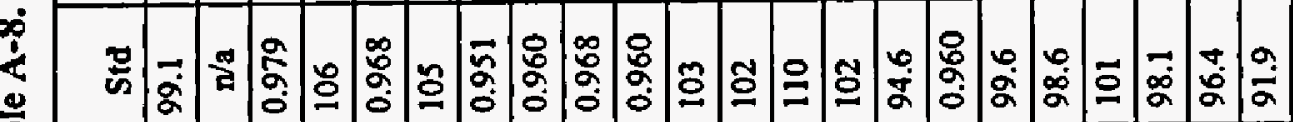

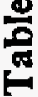

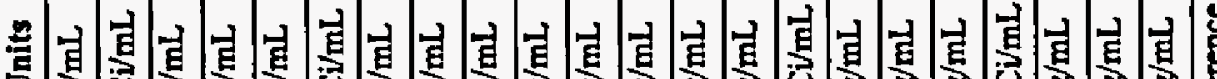

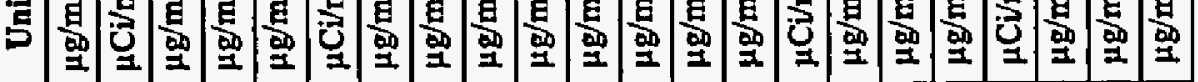

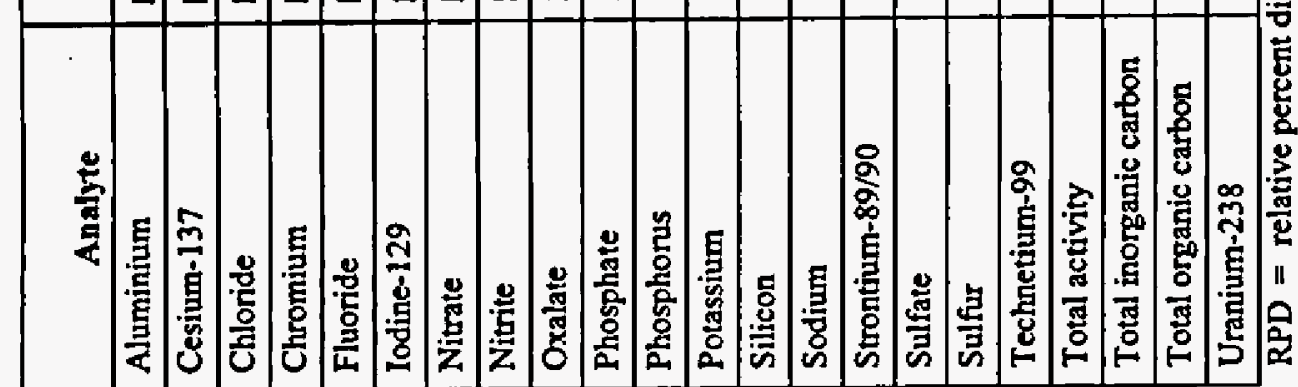


RPP-RPT-31352, Rev. 0

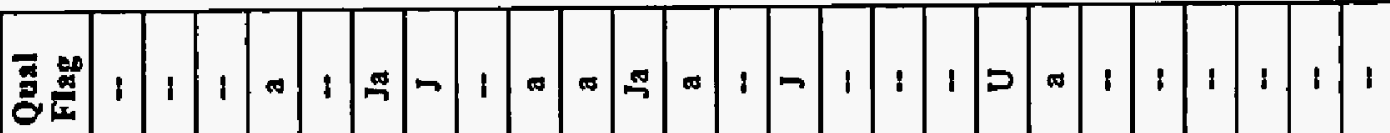

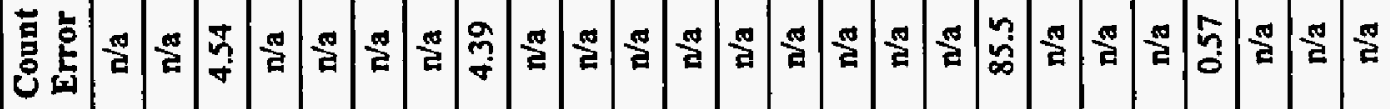

竞晋

运 焉

岗

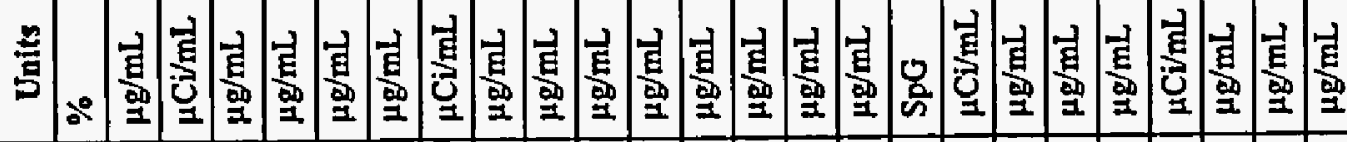

焉 
RPP-RPT-31352, Rev, 0

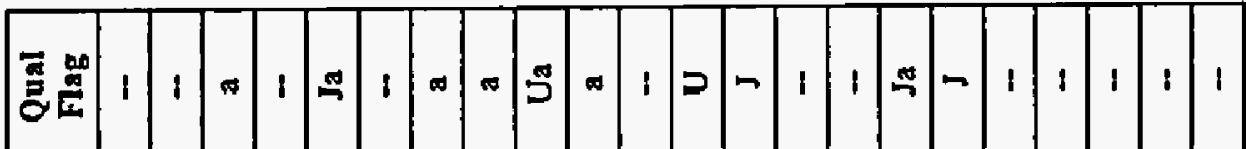

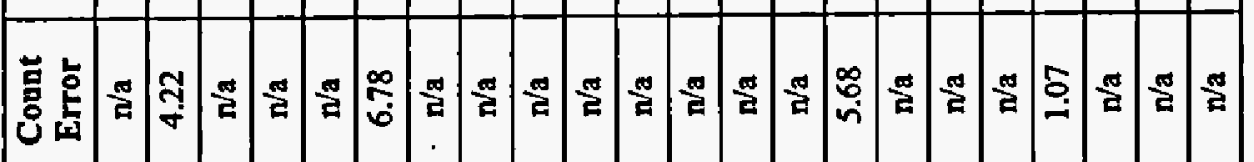

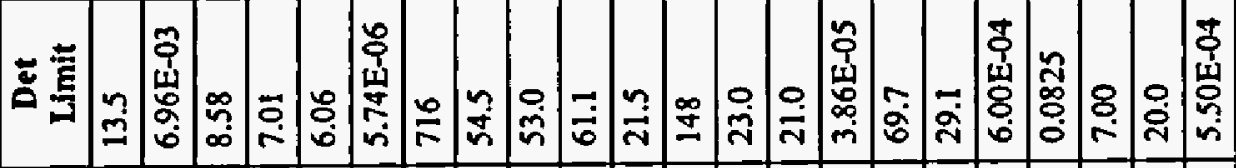

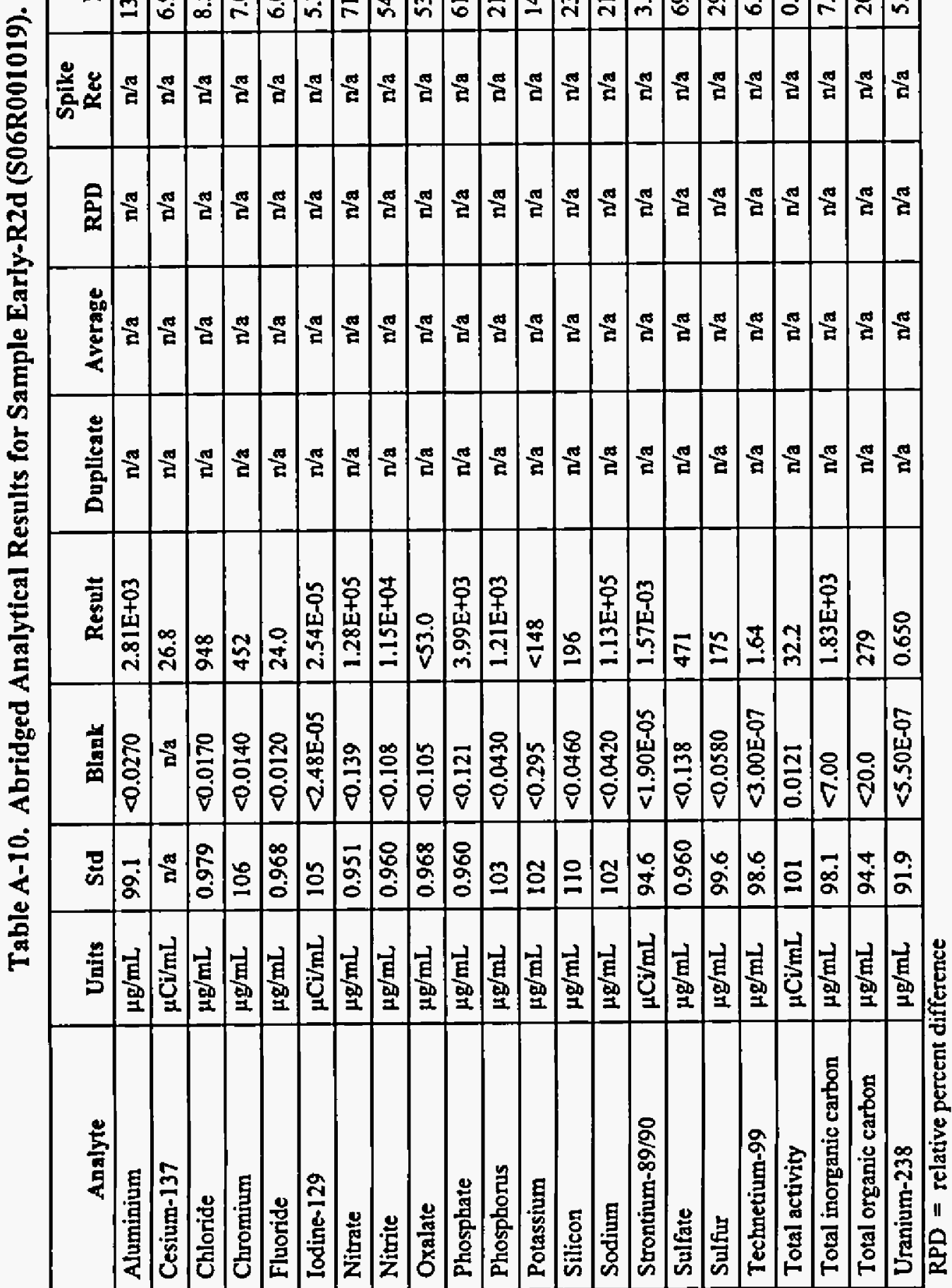

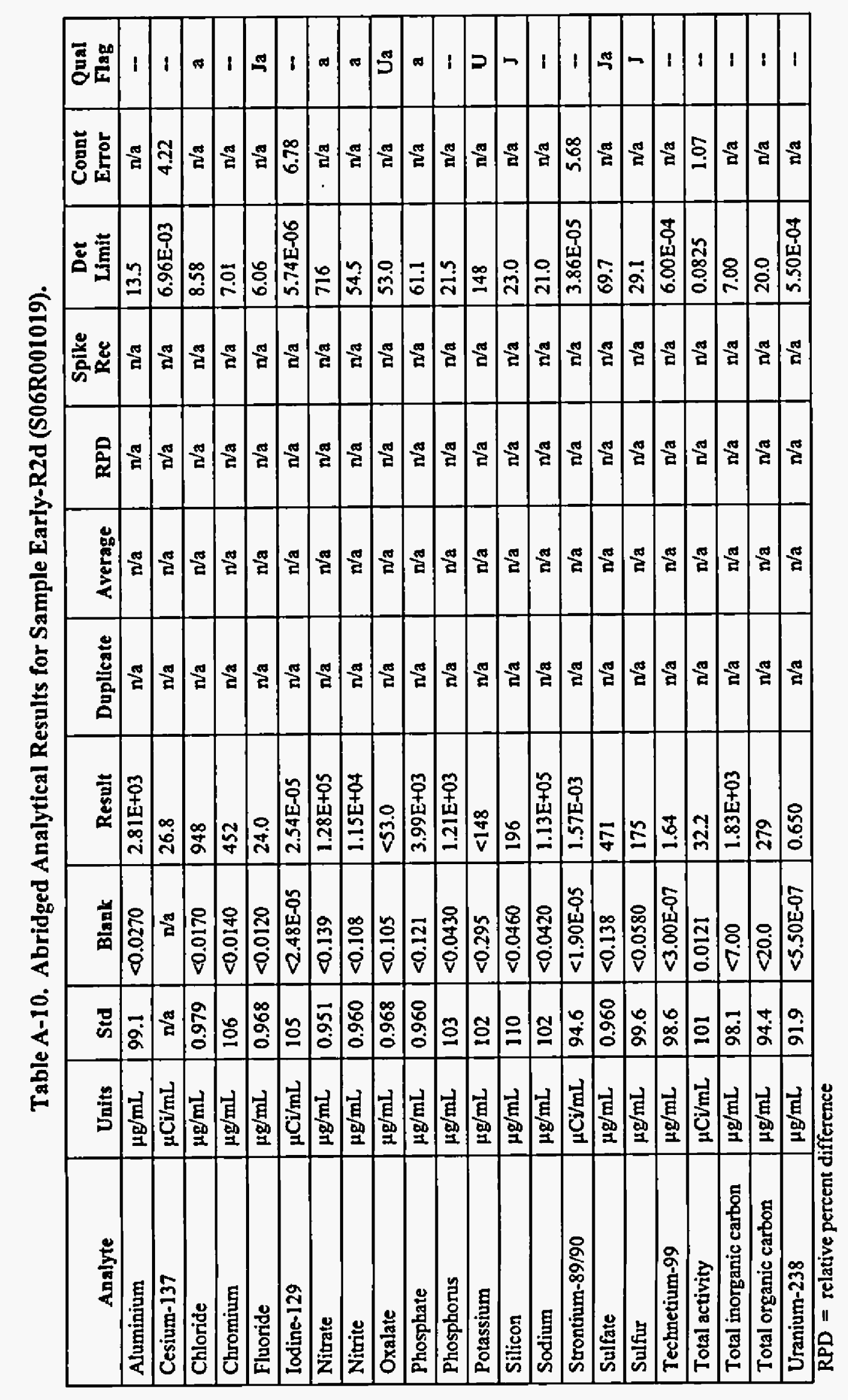

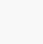




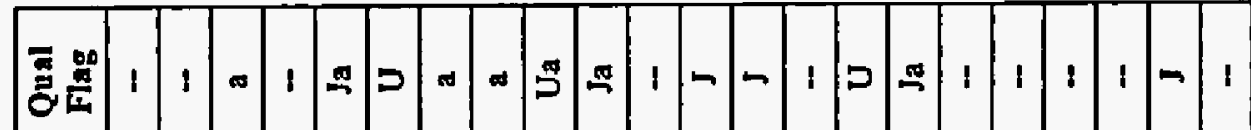

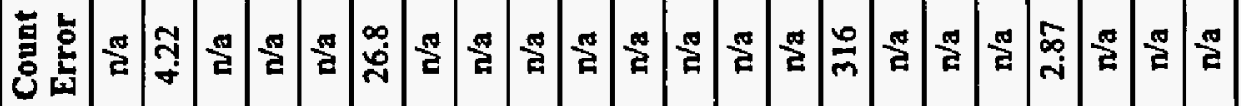

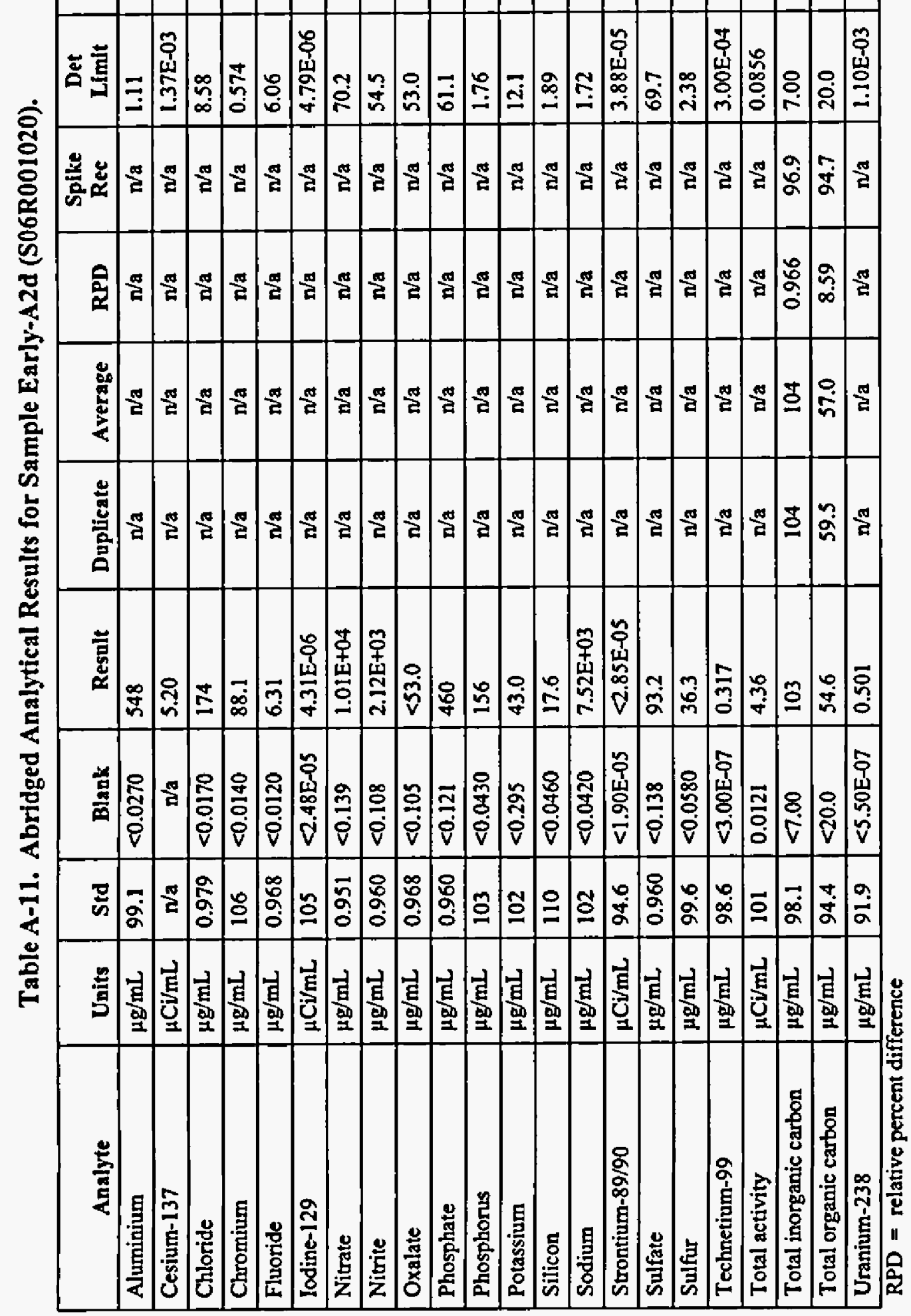


RPP-RPT-31352, Rev. 0

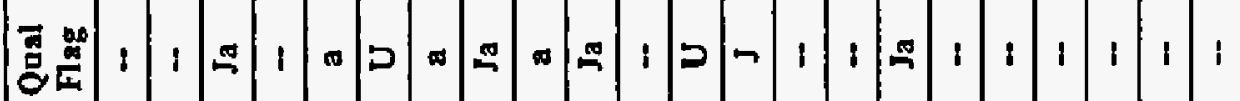

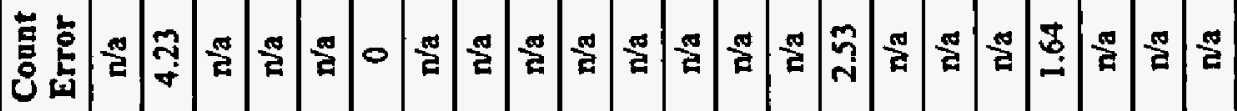

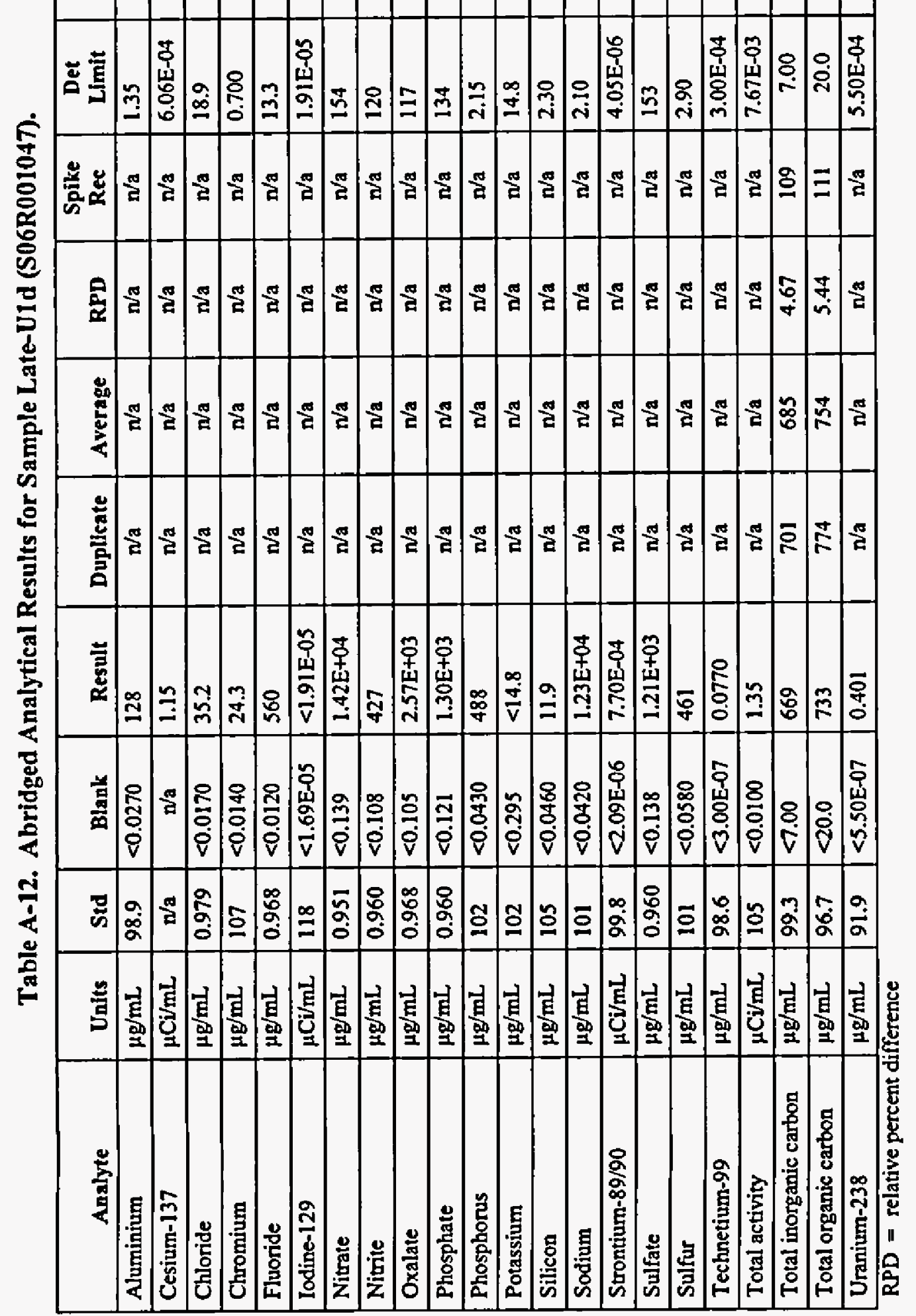

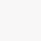

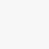


RPP-RPT-31352, Rev. 0

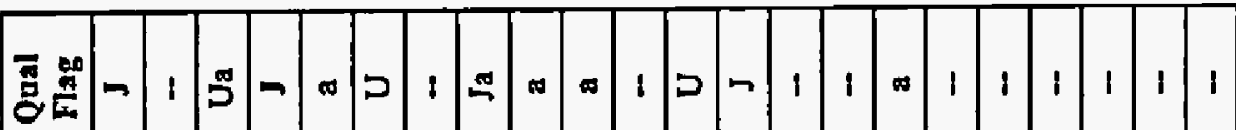

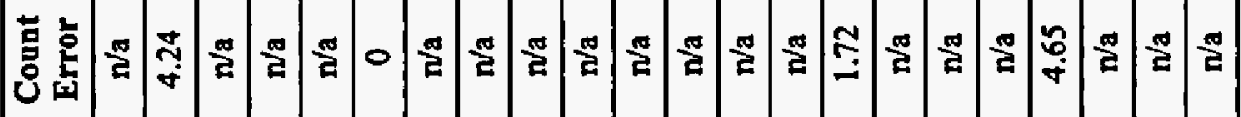

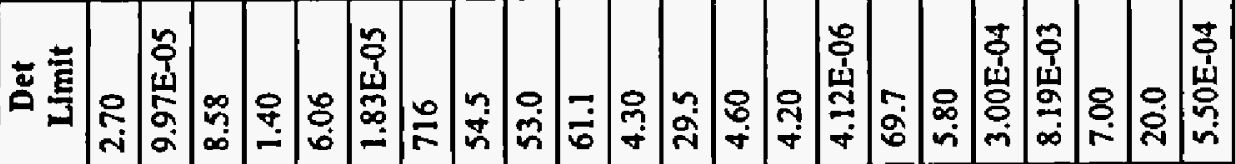

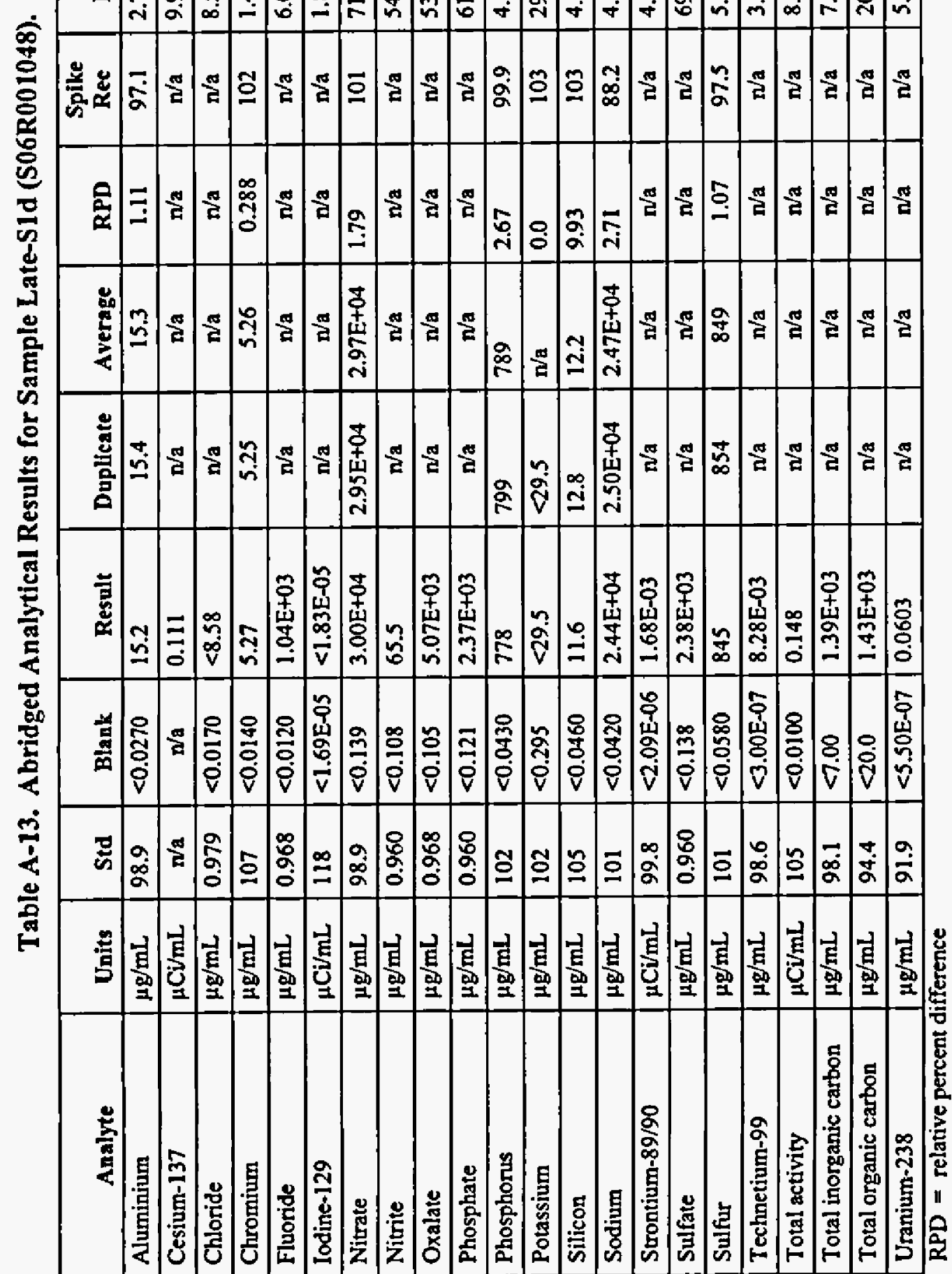


RPP-RPT-31352, Rev. 0

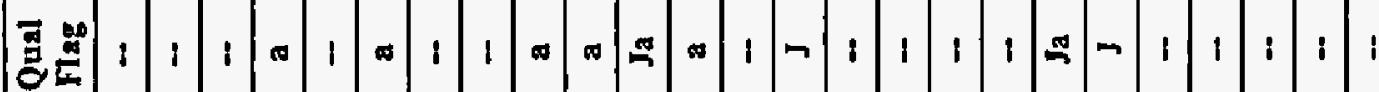

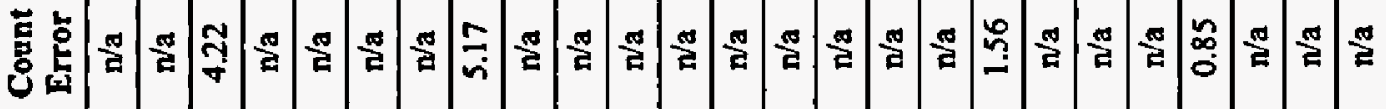

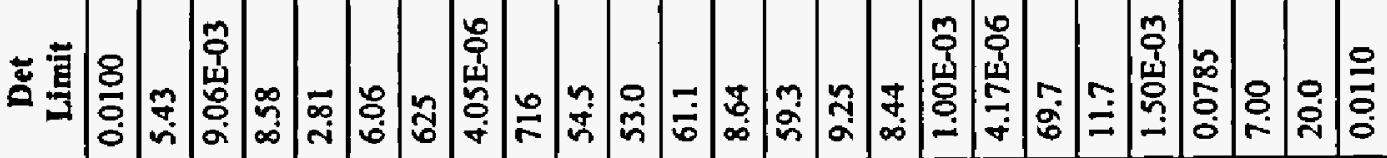

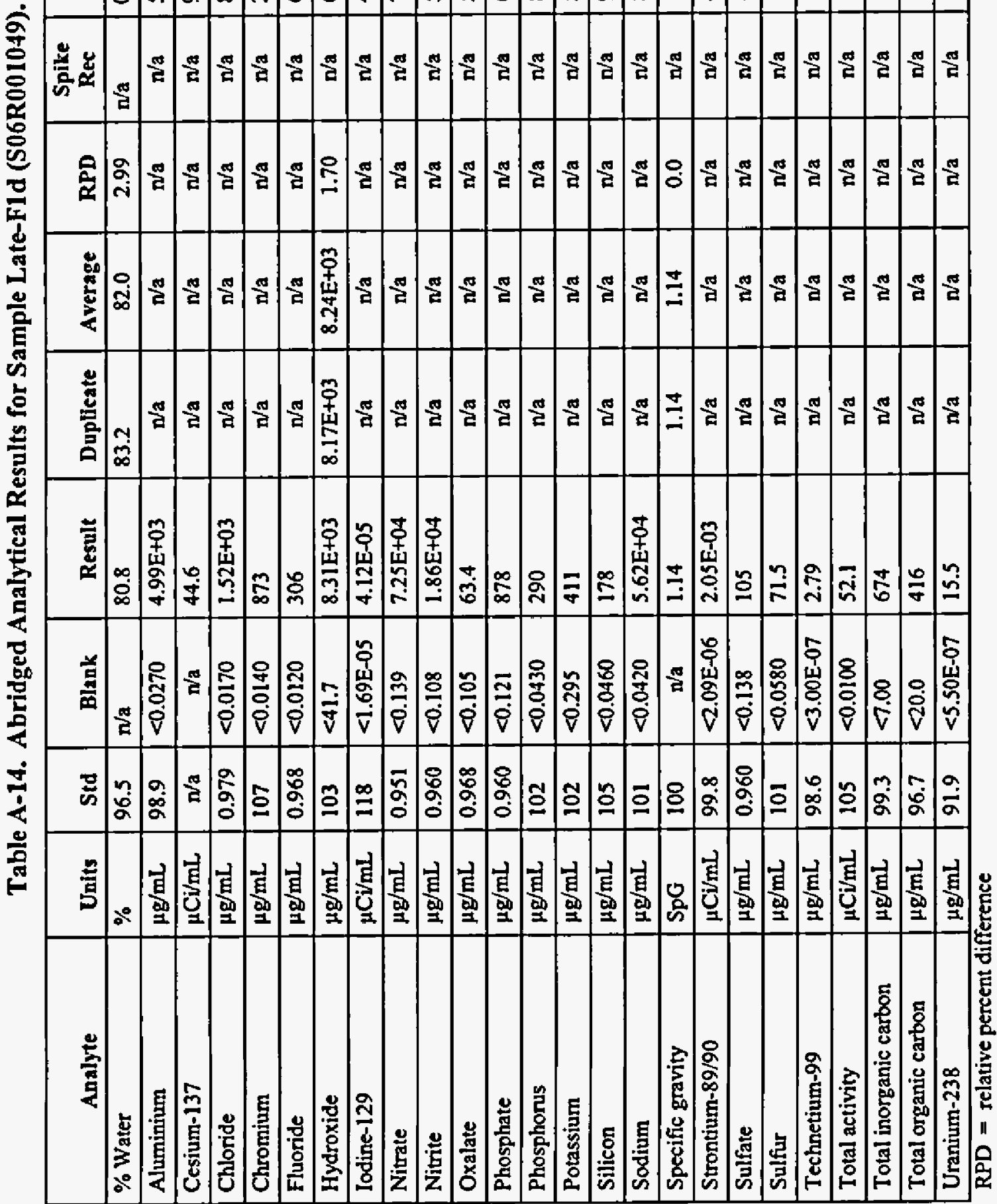


RPP-RPT-31352, Rev. 0

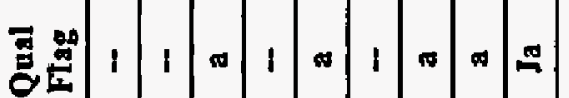

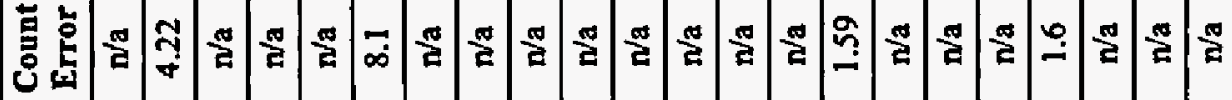

泀旁

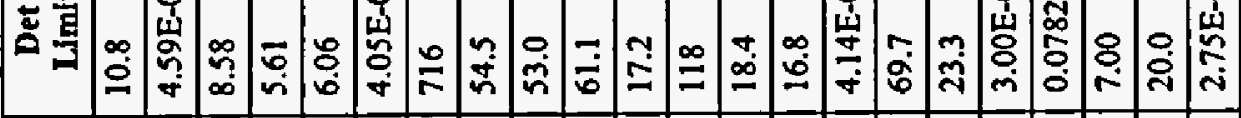

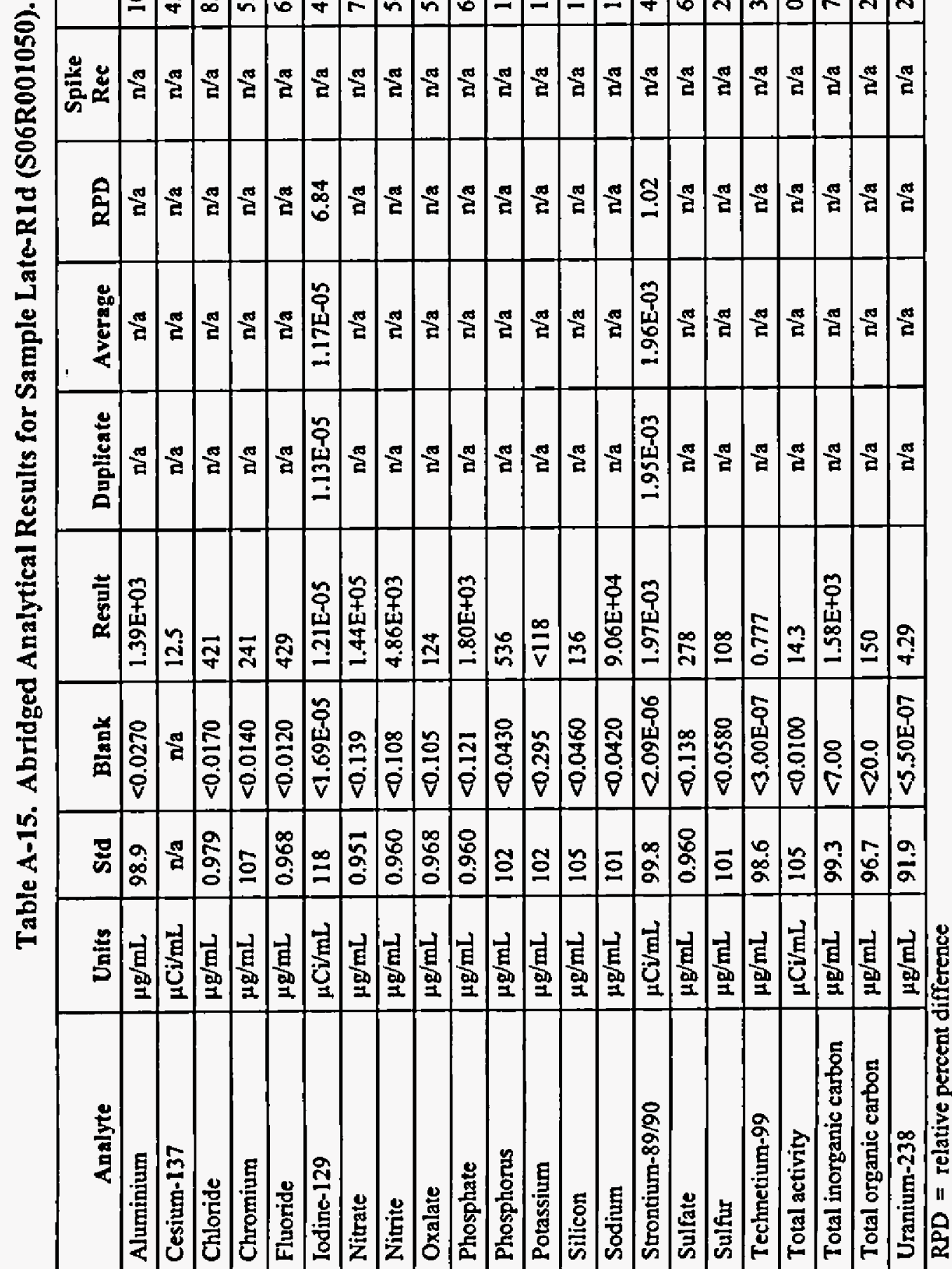


RPP-RPT-31352, Rev. 0

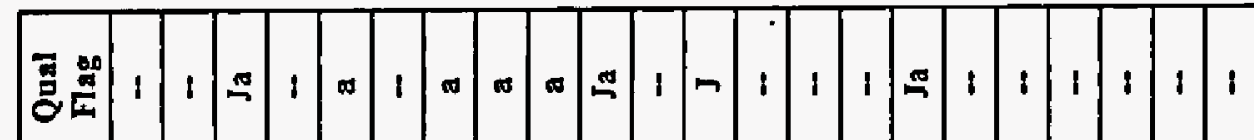

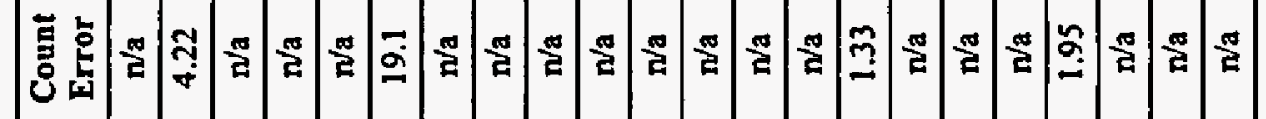

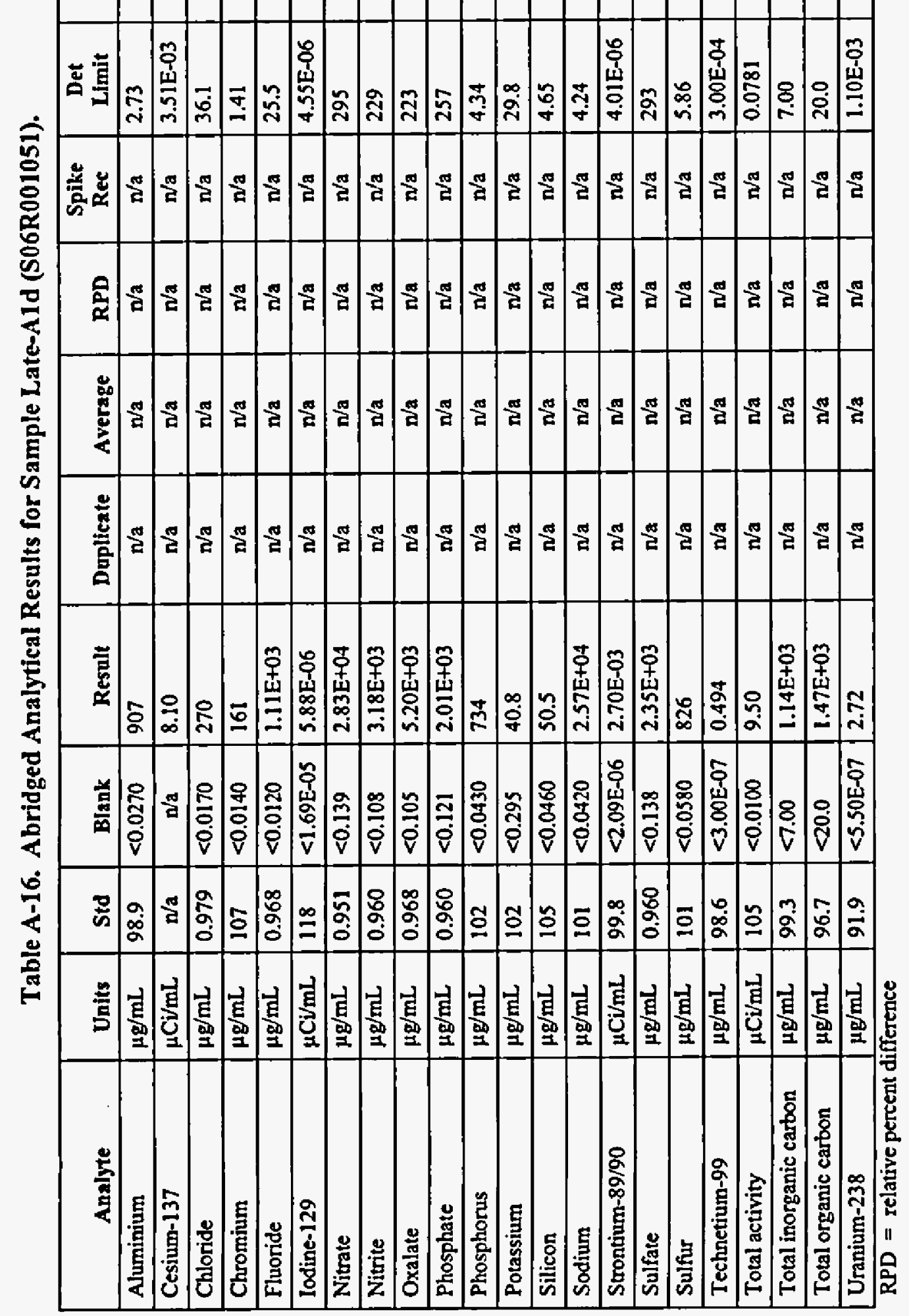

